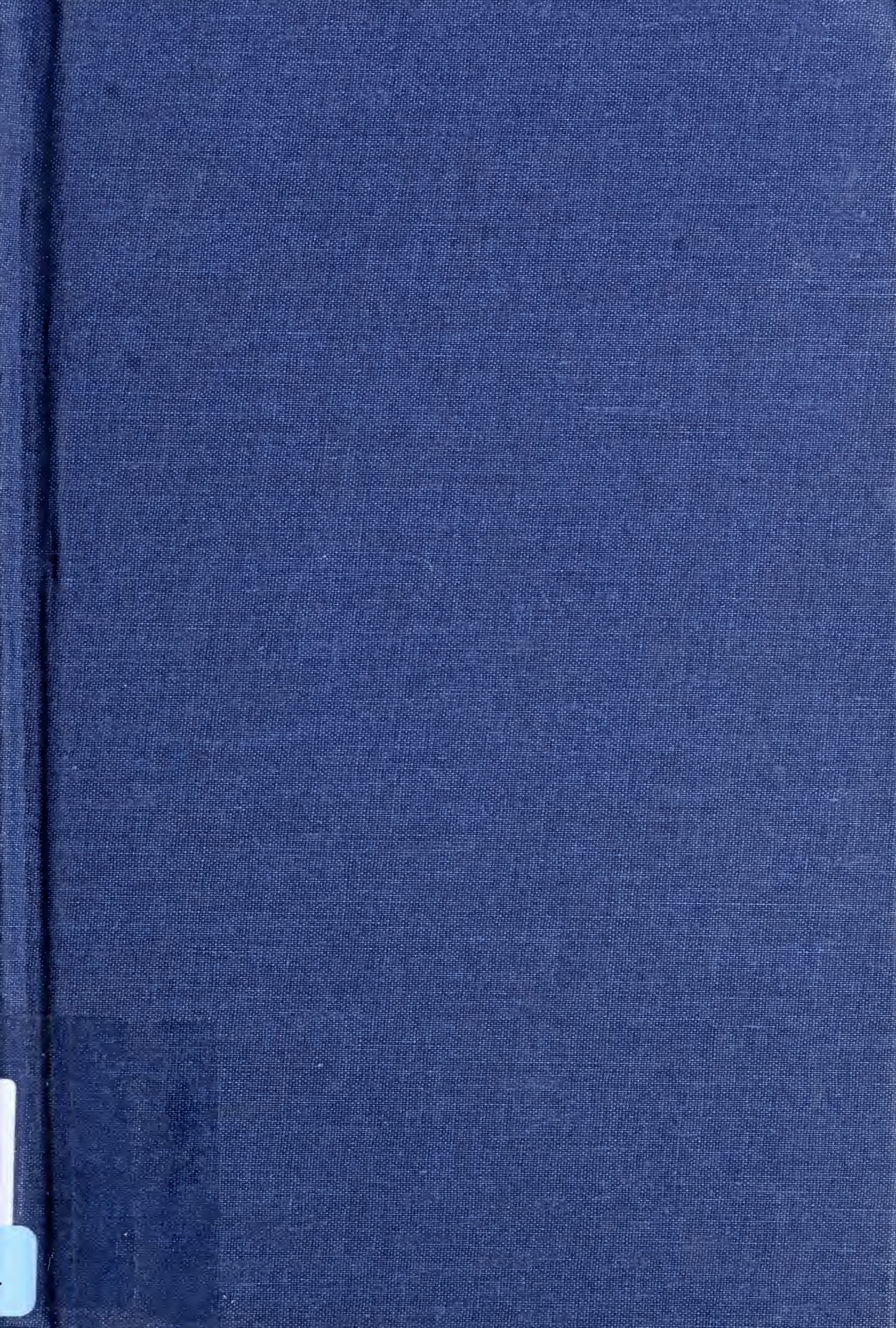


Boston Publlc Lbrery

Boston, MA 02116 

Digitized by the Internet Archive in 2012 


\section{Wild Flowers Worth Knowing}




\section{Wild Flowers Worth Knowing}

Neltje Blanchan

1917 
WILD FLOWERS WORTH KNOWING

Published in the United States by IndyPublish.com Boston, Massachusetts

ISBN 1-4142-4280-8 (hardcover)

ISBN 1-4142-4281-6 (paperback) 


\section{PREFACE}

A still more popular edition of what has proved to the author to be a surprisingly popular book, has been prepared by the abic hand of Mr. Asa Don Dickinson, and is now offered in the hope that many more people will find the wild flowers in Nature's garden all about us well worth knowing. For flowers have distinct objects in life and are everything they are for the most justifiable of reasons, i.e., the perpetuation and the improvement of their species. The means they employ to accomplish these ends are so various and so consummately clever that, in learning to understand them, we are brought to realize how similar they are to the fundamental aims of even the human race. Indeed there are few life principles that plants have not worked out satisfactorily. The problems of adapting oneself to one's environment, of insuring healthy families, of starting one's children well in life, of founding new colonies in distant lands, of the cooperative method of conducting business as opposed to the individualistic, of laying up treasure in the bank for future use, of punishing vice and rewarding virtue - these and many other problems of mankind the flowers have worked out with the help of insects, through the ages. To really understand what the wild flowers are doing, what the scheme of each one is, besides looking beautiful, is to give one a broader sympathy with both man and Nature and to add a real interest and joy to life which cannot be too widely shared.

Neltje Blanchan.

Oyster Bay, New York, January 2, 1917.

Editor's Note.-The nomenclature and classification of Gray's New Manual of Botany, as rearranged and revised by Professors Robinson and Fernald, have been followed throughout the book. This system is based upon that of Eichler, as developed by Engler and Prantl. A variant form of name is also sometimes given to assist in identification.-A.D.D. 



\section{CONTENTS}

Preface, and Editor's Note

WATER-PLANTAIN FAMILY (Alismaceae)

Broad-leaved Arrow-head

ARUM FAMILY (Araceae)

Jack-in-the-Pulpit;

Skunk Cabbage

SPIDERWORT FAMILY (Commelinaceae)

Virginia or Common Day-flower

PICKEREL-WEED FAMILY (Pontederiaceae)

Pickerel Weed

LILY FAMILY (Liliaceae)

American White Hellebore;

Wild Yellow, Meadow,

Field or Canada Lily;

Red, Wood, Flame or Philadelphia Lily;

Yellow Adder's Tongue or Dog-tooth "Violet";

Yellow Clintonia;

Wild Spikenard or False Solomon's Seal;

Hairy, True or Twin-flowered Solomon's Seal;

Early or Dwarf Wake-Robin;

Purple Trillium; 
III-scented Wake-Robin or Birth-root;

Carrion flower

AMARYLLIS FAMILY (Amaryllidaceae)

Yellow Star-grass

IRIS FAMILY (Iridaceae)

Larger Blue Flag, Blue Iris or Fleur-de-lis;

Blackberry Lily;

Pointed Blue-eyed Grass, Eye-bright or Blue Star

ORCHIS FAMILY (Orchidaceae)

Large Yellow Lady's Slipper, Whippoorwill's Shoe or Yellow

Moccasin

Flower;

Moccasin Flower or Pink, Venus' or Stemless Lady's Slipper;

Showy, Gay or Spring Orchis;

Large, Early or Purple-fringed Orchis;

White-fringed Orchis;

Yellow-fringed Orchis;

Calopagon or Grass Pink;

Arethusa or Indian Pink;

Nodding Ladies' Tresses

BUCKWHEAT FAMILY (Polygonaceae)

Common Persicaria, Pink Knotweed or Jointweed or Smartweed

POKEWEED FAMILY (Phytolaccaceae)

Pokeweed, Scoke, Pigeon-berry, Ink-berry or Garget

PINK FAMILY (Caryophyllaceae)

Common Chickweed;

Corn Cockle, Corn Rose, Corn or Red Campion, or Crown-ofthe-Field;

Starry Campion;

Wild Pink or Catchfly;

Soapwort, Bouncing Bet or Old Maid's Pink

PURSLANE FAMILY (Portulacaceae)

Spring Beauty or Claytonia 
WATER-LILY FAMILY (Nymphaeaceae)

Large Yellow Pond or Water Lily, Cow Lily or Spatterdock;

Sweet-scented White Water or Pond Lily

CROWFOOT FAMILY (Ranunculaceae)

Common Meadow Buttercup, Tall Crowfoot or Cuckoo Flower;

Tall Meadow Rue; Liver-leaf, Hepatica, Liverwort or Squirrel

Cup;

Wood Anemone or Wind Flower;

Virgin's Bower, Virginia Clematis or Old Man's Beard;

Marsh Marigold, Meadow-gowan or American Cowslip;

Gold-thread or Canker-root;

Wild Columbine;

Black Cohosh, Black Snakeroot or Tall Bugbane;

White Bane-berry or Cohosh

BARBERRY FAMILY (Berberidaceae)

May Apple, Hog Apple or Mandrake;

Barberry or Pepperidge-bush

POPPY FAMILY (Papaveraceae)

Bloodroot;

Greater Celandine or Swallow-wort

FUMITORY FAMILY (Fumariaceae)

Dutchman's Breeches;

Squirrel Corn

MUSTARD FAMILY (Cruciferae)

Shepherd's Purse;

Black Mustard

PITCHER-PLANT FAMILY (Sarraceniaceae)

Pitcher-plant, Side-saddle Flower or Indian Dipper

SUNDEW FAMILY (Dioseraceae)

Round-leaved Sundew or Dew-plant

SAXIFRAGE FAMILY (Saxifragaceae)

Early Saxifrage;

False Miterwort, Coolwort or Foam Flower;

Grass of Parnassus 
WITCH-HAZEL FAMILY (Hamamelidaceae)

Witch-hazel

\section{ROSE FAMILY (Rosaceae)}

Hardhack or Steeple Bush;

Meadow-Sweet or Quaker Lady;

Common Hawthorn, White Thorn, Red Haw or Mayflower;

Five-finger or Common Cinquefoil;

High Bush Blackberry, or Bramble;

Purple-flowering or Virginia Raspberry;

Wild Roses

\section{PULSE FAMILY (Leguminosae)}

Wild or American Senna;

Wild Indigo, Yellow or Indigo Broom, or Horsefly-Weed;

Wild Lupine, Sun Dial or Wild Pea;

Common Red, Purple, Meadow or Honeysuckle Clover;

White Sweet, Bokhara or Tree Clover;

Blue, Tufted or Cow Vetch or Tare;

Ground-nut;

Wild or Hog Peanut

WOOD-SORREL FAMILY (Oxalidaceae)

White or True Wood-sorrel or Alleluia;

Violet Wood-sorrel

\section{GERANIUM FAMILY (Geraniaceae)}

Wild or Spotted Geranium or Crane's-Bill;

Herb Robert, Red Robin or Red Shanks

MILKWORT FAMILY (Polygalaceae)

Fringed Milkwort or Polygala or Flowering Wintergreen;

Common Field or Purple Milkwort

TOUCH-ME-NOT FAMILY (Balsaminaceae)

Jewel-weed, Spotted Touch-me-not or Snap Weed

BUCKTHORN FAMILY (Rhamnaceae)

New Jersey Tea 
MALLOW FAMILY (Malvaceae)

Swamp Rose-mallow or Mallow Rose

ST. JOHN'S-WORT FAMILY (Hypericaceae)

Common St. John's-wort

ROCKROSE FAMILY (Cistaceae)

Long-branched Frost-weed or Canadian Rockrose

VIOLET FAMILY (Violaceae)

Blue and Purple Violets;

Yellow Violets;

White Violets

EVENING PRIMROSE FAMILY (Onagraceae)

Great or Spiked Willow-herb or Fire-weed;

Evening Primrose or Night Willow-herb

GINSENG FAMILY (Araliaceae)

Spikenard or Indian Root

PARSLEY FAMILY (Umbelliferae)

Wild or Field Parsnip;

Wild Carrot or Queen Anne's Lace

DOGWOOD FAMILY (Cornaceae)

Flowering Dogwood

HEATH FAMILY (Ericaceae)

Pipsissewa or Prince's Pine;

Indian Pipe, Ice-plant, Ghost flower or Corpse-plant;

Pine Sap or False Beech-drops;

Wild Honeysuckle, Pink, Purple or Wild Azalea, or Pinxter-

flower;

American or Great Rhododendron, Great Laurel, or Bay;

Mountain or American Laurel or Broad-leaved Kalmia;

Trailing Arbutus or Mayflower;

Creeping Wintergreen, Checker-berry or Partridge-berry

PRIMROSE FAMILY (Primulaceae)

Four-leaved or Whorled Loosestrife;

Star-flower; 
Scarlet Pimpernel, Poor Man's Weatherglass or Shepherd's Clock; Shooting Star or American Cowslip

GENTIAN FAMILY (Gentianaceae)

Bitter-bloom or Rose-Pink;

Fringed Gentian;

Closed or Blind Gentian

DOGBANE FAMILY (Apocynaceae) Spreading or Fly-trap Dogbane

MILKWEED FAMILY (Asclepiadaceae)

Common Milkweed or Silkweed;

Butterfly-weed

CONVOLVULUS FAMILY (Convolvulaceae)

Hedge or Great Bindweed;

Gronovius' or Common Dodder or Strangle-weed

POLEMONIUM FAMILY (Polemoniaceae)

Ground or Moss Pink

BORAGE FAMILY (Boraginaceae)

Forget-me-not;

Viper's Bugloss or Snake-flower

VERVAIN FAMILY (Verbenaceae)

Blue Vervain, Wild Hyssop or Simpler's Joy

MINT FAMILY (Labiatae)

Mad-dog Skullcap or Madweed;

Self-heal, Heal-all, Blue Curls or Brunella;

Motherwort;

Oswego Tea, Bee Balm or Indian's Plume;

Wild Bergamot

NIGHTSHADE FAMILY (Solanaceae)

Nightshade, Blue Bindweed or Bittersweet; Jamestown Weed, Thorn Apple or Jimson Weed 
FIGWORT FAMILY (Scrophulariaceae)

Great Mullein, Velvet or Flannel Plant or Aaron's Rod;

Moth Mullein;

Butter-and-eggs or Yellow Toadflax;

Blue or Wild Toadflax or Blue Linaria;

Hairy Beard-tongue;

Snake-head, Turtle-head or Cod-head;

Monkey-flower;

Common Speedwell, Fluellin or Paul's Betony;

American Brooklime;

Culver's-root;

Downy False Foxglove;

Large Purple Gerardia;

Scarlet Painted Cup or Indian Paint-brush;

Wood Betony or Loosewort

BROOM-RAPE FAMILY (Orobanchaceae)

Beech-drops

MADDER FAMILY (Rubiaceae)

Partridge Vine or Squaw-berry;

Button-bush or Honey-balls;

Bluets, Innocence or Quaker Ladies

BLUEBELL FAMILY (Campanulaceae)

Harebell, Hairbell or Blue Bells of Scotland; Venus' Looking-glass or Clasping Bellflower

LOBELIA FAMILY (Lobeliaceae)

Cardinal Flower;

Great Lobelia

COMPOSITE FAMILY (Compositae)

Iron-weed or Flat Top;

Joe Pye Weed, Trumpet Weed, or Tall or Purple Boneset or

Thoroughwort;

Golden-rods;

Blue and Purple Asters or Starworts;

White Asters or Starworts;

Golden Aster;

Daisy Fleabane or Sweet Scabious; 
Robin's or Robert's Plantain or Blue Spring Daisy;

Pearly or Large-flowered Everlasting or Immortelle, Elecampane or Horseheal;

Black-eyed Susan or Yellow or Ox-eye Daisy;

Tall or Giant Sunflower;

Sneezeweed or Sivamp Sunflower;

Yarrow or Milfoil;

Dog's or Fetid Camomile or Dog-fennel;

Common Daisy, Marguerite, or White Daisy;

Tansy or Bitter Buttons;

Thistles; Chicory or Succory;

Common Dandelion;

Tall or Wild Lettuce;

Orange or Tawny Hawkweed or Devil's Paint-brush

COLOR KEY

GENERAL INDEX OF NAMES 




\section{WATER-PLANTAIN FAMILY (Alismaceae)}

\section{Broad-leaved Arrow-head}

\section{Sagittaria latifolia (S. variabilis)}

Flowers-White, 1 to $1-1 / 2$ in. wide, in 3-bracted whorls of 3 , borne near the summit of a leafless scape $4 \mathrm{in}$. to $4 \mathrm{ft}$. tall. Calyx of 3 sepals; corolla of 3 rounded, spreading petals. Stamens and pistils numerous, the former yellow in upper flowers; usually absent or imperfect in lower pistillate flowers. Leaves: Exceedingly' variable; those under water usually long and grass-like; upper ones sharply arrowshaped or blunt and broad, spongy or leathery, on long petioles.

Preferred Habitat-Shallow water and mud.

Flowering Season-July-September.

Distribution-From Mexico northward throughout our area to the circumpolar regions.

Wading into shallow water or standing on some muddy shore, like a heron, this striking plant, so often found in that bird's haunts, is quite as decorative in a picture, and, happily, far more approachable in life. Indeed, one of the comforts of botany as compared with bird study is that we may get close enough to the flowers to observe their last detail, whereas the bird we have followed laboriously over hill and dale, through briers and swamps, darts away beyond the range of fieldglasses with tantalizing swiftness. 
While no single plant is yet thoroughly known to scientists, in spite of the years of study devoted by specialists to separate groups, no plant remains wholly meaningless. When Keppler discovered the majestic order of movement of the heavenly bodies, he exclaimed, "O God, I think Thy thoughts after Thee!"- - the expression of a discipleship every reverent soul must be conscious of in penetrating, be it ever so little a way, into the inner meaning of the humblest wayside weed.

Any plant which elects to grow in shallow water must be amphibious: it must be able to breathe beneath the surface as the fish do, and also be adapted to thrive without those parts that correspond to gills; for ponds and streams have an unpleasant way of drying up in summer, leaving it stranded on the shore. This accounts in part for the variable leaves on the arrow-head, those underneath the water being long and ribbon-like, to bring the greatest possible area into contact with the air with which the water is charged. Broad leaves would be torn to shreds by the current through which grass-like blades glide harmlessly; but when this plant grows on shore, having no longer use for its lower ribbons, it loses them, and expands only broad arrow-shaped surfaces to the sunny air, leaves to be supplied with carbonic acid to assimilate, and sunshine to turn off, the oxygen and store up the carbon into their system. 


\section{ARUM FAMILY (Araceae)}

Jack-in-the-Pulpit; Indian Turnip

Arisaema triphyllum

Flowers-Minute, greenish yellow, clustered on the lower part of a smooth, clubshaped, slender spadix within a green and maroon or whitish-striped spathe that curves in a broad-pointed flap above it. Leaves: 3-foliate, usually overtopping the spathe, their slender petioles 9 to $30 \mathrm{in}$. high, or as tall as the scape that rises from an acrid corm. Fruit: Smooth, shining red berries clustered on the thickened club.

Preferred Habitat-Moist woodland and thickets.

Flowering Season-April-June.

Distribution-Nova Scotia westward to Minnesota, and southward to the Gulf states.

A jolly-looking preacher is Jack, standing erect in his parti-colored pulpit with a sounding-board over his head; but he is a gay deceiver, a wolf in sheep's clothing, literally a "brother to dragons," an arrant upstart, an ingrate, a murderer of innocent benefactors! "Female botanizing classes pounce upon it as they would upon a pious young clergyman," complains Mr. Ellwanger. A poor relation of the stately calla lily one knows Jack to be at a glance, her lovely white robe corresponding to his striped pulpit, her bright yellow spadix to his sleek reverence. In the damp woodlands where his pulpit is erected beneath leafy cathedral arches, minute flies 
or gnats, recently emerged from maggots in mushrooms, toadstools, or decaying logs, form the main part of his congregation.

Now, to drop the clerical simile, let us peep within the sheathing spathe, or, better still, strip it off altogether. Doctor Torrey states that the dark-striped spathes are the fertile plants, those with green and whitish lines, sterile. Within are smooth, glossy columns, and near the base of each we shall find the true flowers, minute affairs, some staminate; others, on distinct plants, pistillate, the berry bearers; or rarely both male and female florets seated on the same club, as if Jack's elaborate plan to prevent self-fertilization were not yet complete. Plants may be detected in process of evolution toward their ideals just as nations and men are. Doubtless when Jack's mechanism is perfected, his guilt will disappear. A little way above the florets the club enlarges abruptly, forming a projecting ledge that effectually closes the avenue of escape for many a guileless victim. A fungous gnat, enticed perhaps by the striped house of refuge from cold spring winds, and with a prospect of food below, enters and slides down the inside walls or the slippery, colored column: in either case descent is very easy; it is the return that is made so difficult, if not impossible, for the tiny visitors. Squeezing past the projecting ledge, the gnat finds himself in a roomy apartment whose floor-the bottom of the pulpit-is dusted over with fine pollen; that is, if he is among staminate flowers already mature. To get some of that pollen, with which the gnat presently covers himself, transferred to the minute pistillate florets waiting for it in a distant chamber is, of course, Jack's whole aim in enticing visitors within his polished walls; but what means are provided for their escape? Their efforts to crawl upward over the slippery surface only land them weak and discouraged where they started. The projecting ledge overhead prevents them from using their wings; the passage between the ledge and the spathe is far too narrow to permit flight. Now, if a gnat be persevering, he will presently discover a gap in the flap where the spathe folds together in front, and through this tiny opening he makes his escape, only to enter another pulpit, like the trusted, but too trusting, messenger he is, and leave some of the vitalizing pollen on the fertile florets awaiting his coming.

But suppose the fly, small as he is, is too large to work his way out through the flap, or too bewildered or stupid to find the opening, or too exhausted after his futile efforts to get out through the overhead route to persevere, or too weak with hunger in case of long detention in a pistillate trap where no pollen is, what then? Open a dozen of Jack's pulpits, and in several, at least, dead victims will be found-pathetic little corpses sacrificed to the imperfection of his executive system. Had the flies entered mature spathes, whose walls had spread outward and away from the polished column, flight through the overhead route might have been possible. However glad we may be to make every due allowance for this sac- 
rifice of the higher life to the lower, as only a temporary imperfection of mechanism incidental to the plant's higher development, Jack's present cruelty shocks us no less. Or, it may be, he will become insectivorous like the pitcher plant in time. He comes from a rascally family, anyhow. His cousin, the cuckoo-pint, as is well known, destroys the winged messenger bearing its offspring to plant fresh colonies in a distant bog, because the decayed body of the bird acts as the best possible fertilizer into which the seedling may strike its roots.

In June and July the thick-set club, studded over with bright berries, becomes conspicuous, to attract hungry woodland rovers in the hope that the seeds will be dropped far from the parent plant. The Indians used to boil the berries for food. The farinaceous root (corm) they likewise boiled or dried to extract the stinging, blistering juice, leaving an edible little "turnip," however insipid and starchy.

\section{Skunk or Swamp Cabbage}

\section{Symplocarpus foetidus}

Flowers-Minute, perfect, foetid; many scattered over a thick, rounded, fleshy spadix, and hidden within a swollen, shell-shaped, purplish-brown to greenishyellow, usually mottled, spathe, close to the ground, that appears before the leaves. Spadix much enlarged and spongy in fruit, the bulb-like berries imbedded in its surface. Leaves: In large crowns like cabbages, broadly ovate, often $1 \mathrm{ft}$. across, strongly nerved, their petioles with deep grooves, malodorous.

Preferred Habitat-Swamps, wet ground.

Flowering Season-February-April.

Distribution-Nova Scotia to Florida, and westward to Minnesota and Iowa.

This despised relative of the stately calla lily proclaims spring in the very teeth of winter, being the first bold adventurer above ground. When the lovely hepatica, the first flower worthy the name to appear, is still wrapped in her fuzzy furs, the skunk cabbage's dark, incurved horn shelters within its hollow, tiny, malodorous florets. Why is the entire plant so foetid that one flees the neighborhood, pervaded as it is with an odor that combines a suspicion of skunk, putrid meat, and garlic? After investigating the Carrion-flower and the Purple Trillium, among others, we learned that certain flies delight in foul odors loathsome to higher organisms; that plants dependent on these pollen carriers woo them from long distances with a stench, and in addition sometimes try to charm them with color resem- 
bling the sort of meat it is their special mission, with the help of beetles and other scavengers of Nature, to remove from the face of the earth. In such marshy ground as the Skunk Cabbage lives in, many small flies and gnats live in embryo under the fallen leaves during the winter. But even before they are warmed into active life, the hive-bees, natives of Europe, and with habits not perfectly adapted as yet to our flora, are out after pollen.

After the flowering time come the vivid green crowns of leaves that at least please the eye. Lizards make their home beneath them, and many a yellowthroat, taking advantage of the plant's foul odor, gladly puts up with it herself and builds her nest in the hollow of the cabbage as a protection for her eggs and young from four-footed enemies. Cattle let the plant alone because of the stinging acrid juices secreted by it, although such tender, fresh, bright foliage must be especially tempting, like the hellebore's, after a dry winter diet. Sometimes tiny insects are found drowned in the wells of rain water that accumulate at the base of the grooved leafstalks. 


\section{SPIDERWORT FAMILY (Commelinaceae)}

Virginia, or Common Day-flower

Commelina virginica

Flowers-Blue, $1 \mathrm{in}$. broad or less, irregular, grouped at end of stem, and upheld by long leaf-like bracts. Calyx of 3 unequal sepals; 3 petals, 1 inconspicuous, 2 showy, rounded. Perfect stamens 3; the anther of 1 incurved stamen largest; 3 insignificant and sterile stamens; 1 pistil. Stem: Fleshy, smooth, branched, mucilaginous. Leaves: Lance-shaped, 3 to $5 \mathrm{in}$. long, sheathing the stem at base; upper leaves in a spathe-like bract folding like a hood about flowers. Fruit: A 3celled capsule, 1 seed in each cell.

Preferred Habitat-Moist, shady ground.

Flowering Season-June-September.

Distribution-"Southern New York to Illinois and Michigan, Nebraska, Texas, and through tropical America to Paraguay."-Britton and Browne.

Delightful Linnaeus, who dearly loved his little joke, himself confesses to have named the day-flowers after three brothers Commelyn, Dutch botanists, because two of them-commemorated in the two showy blue petals of the blossompublished their works; the third, lacking application and ambition, amounted to nothing, like the inconspicuous whitish third petal! Happily Kaspar Commelyn died in 1731, before the joke was perpetrated in "Species Plantarum." Soon after noon, the day-flower's petals roll up, never to open again. 


\section{PICKEREL-WEED FAMILY (Pontederiaceae)}

\section{Pickerel Weed}

\section{Pontederia cordata}

Flowers-Bright purplish blue, including filaments, anthers, and style; crowded in a dense spike; quickly fading; unpleasantly odorous. Perianth tubular, 2-lipped, parted into 6 irregular lobes, free from ovary; middle lobe of upper lip with 2 yellow spots at base within. Stamens 6 , placed at unequal distances on tube, 3 opposite each lip. Pistil 1, the stigma minutely toothed. Stem: Erect, stout, fleshy, 1 to $4 \mathrm{ft}$. tall, not often over $2 \mathrm{ft}$. above water line. Leaves: Several bract-like, sheathing stem at base; 1 leaf only, midway on flower-stalk, thick, polished, triangular, or arrow-shaped, 4 to 8 in. long, 2 to 6 in. across base.

Preferred Habitat-Shallow water of ponds and streams.

Flowering Season-June-October.

Distribution-Eastern half of United States and Canada.

Grace of habit and the bright beauty of its long blue spikes of ragged flowers above rich, glossy leaves give a charm to this vigorous wader. Backwoodsmen will tell you that pickerels lay their eggs among the leaves; but so they do among the sedges, arums, wild rice, and various aquatic plants, like many another fish. Bees and flies, that congregate about the blossoms to feed, may sometimes fly too low, and so give a plausible reason for the pickerel's choice of haunt. Each blossom lasts 
but a single day; the upper portion, withering, leaves the base of the perianth to harden about the ovary and protect the solitary seed. But as the gradually lengthened spike keeps up an uninterrupted succession of bloom for months, more than ample provision is made for the perpetuation of the race-a necessity to any plant that refuses to thrive unless it stands in water. Ponds and streams have an unpleasant habit of drying up in summer, and often the Pickerel Weed looks as brown as a bullrush where it is stranded in the baked mud in August. When seed falls on such ground, if indeed it germinates at all, the young plant naturally withers away.

Of the three kinds of blossoms, one raises its stigma on a long style reaching to the top of the flower; a second form reaches its stigma only half-way up, and the third keeps its stigma in the bottom of the tube. The visiting bee gets his abdomen, his chest, and his tongue dusted with pollen from long, middle-length, and short stamens respectively. When he visits another flower, these parts of his body coming in contact with the stigmas that occupy precisely the position where the stamens were in other individuals, he brushes off each lot of pollen just where it will do the most good. 


\section{LILY FAMILY (Liliaceae)}

American White Hellebore; Indian Poke; Itch-weed

Veratrum viride

Flowers-Dingy, pale yellowish or whitish green, growing greener with age, $1 \mathrm{in}$. or less across, very numerous, in stiff-branching, spike-like, dense-flowered panicles. Perianth of 6 oblong segments; 6 short curved stamens; 3 styles. Stem: Stout, leafy, 2 to $8 \mathrm{ft}$. tall. Leaves: Plaited, lower ones broadly oval, pointed, 6 to $12 \mathrm{in}$. long; parallel ribbed, sheathing the stem where they clasp it; upper leaves gradually narrowing; those among flowers small.

Preferred Habitat-Swamps, wet woods, low meadows.

Flowering Season-May-July.

Distribution-British Possessions from ocean to ocean; southward in the United States to Georgia, Tennessee, and Minnesota.

"Borage and hellebore fill two scenes-

Sovereign plants to purge the veins

Of melancholy, and cheer the heart

Of those black fumes which make it smart."

Such are the antidotes for madness prescribed by Burton in his "Anatomie of Melancholy." But like most medicines, so the homoeopaths have taught us, the 
plant that heals may also poison; and the coarse, thick rootstock of this hellebore sometimes does deadly work. The shining plaited leaves, put forth so early in the spring they are especially tempting to grazing cattle on that account, are too well known by most animals, however, to be touched by them-precisely the end desired, of course, by the hellebore, nightshade, aconite, cyclamen, Jamestown weed, and a host of others that resort, for protection, to the low trick of mixing poisonous chemicals with their cellular juices. Pliny told how the horses, oxen, and swine of his day were killed by eating the foliage of the black hellebore. But the flies which cross-fertilize this plant seem to be uninjured by its nectar.

Wild Yellow, Meadow, or Field Lily; Canada Lily

\section{Lilium canadense}

Flowers-Yellow to orange-red, of a deeper shade within, and speckled with dark, reddish-brown dots. One or several (rarely many) nodding on long peduncles from the summit. Perianth bell-shaped, of 6 spreading segments 2 to 3 in. long, their tips curved backward to the middle; 6 stamens, with redidish-brown linear anthers; 1 pistil, club-shaped; the stigma 3-lobed. Stem: 2 to $5 \mathrm{ft}$. tall, leafy, from a bulbous rootstock composed of numerous fleshy white scales. Leaves: Lanceshaped to oblong; usually in whorls of fours to tens, or some alternate. Fruit: An erect, oblong, 3-celled capsule, the flat, horizontal seeds packed in 2 rows in each cavity.

Preferred Habitat-Swamps, low meadows, moist fields.

Flowering Season-June-July.

Distribution-Nova Scotia to Georgia, westward beyond the Mississippi.

Not our gorgeous lilies that brighten the low-lying meadows in early summer with pendent, swaying bells; possibly not a true lily at all was chosen to illustrate the truth which those who listened to the Sermon on the Mount, and we, equally anxious, foolishly overburdened folk of to-day, so little comprehend.

"Consider the lilies of the field, how they grow; they toil not, neither do they spin:

"And yet I say unto you, that even Solomon in all his glory was not arrayed like one of these."

Opinions differ as to the lily of Scripture. Eastern peoples use the same word interchangeably for the tulip, anemone, ranunculus, iris, the water-lilies, and 
those of the field. The superb scarlet Martagon Lily (L. chalcedonicum), grown in gardens here, is not uncommon wild in Palestine; but whoever has seen the large anemones there "carpeting every plain and luxuriantly pervading the land" is inclined to believe that Jesus, who always chose the most familiar objects in the daily life of His simple listeners to illustrate His teachings, rested His eyes on the slopes about Him glowing with anemones in all their matchless loveliness. What flower served Him then matters not at all. It is enough that scientists-now more plainly than ever before - see the universal application of the illustration the more deeply they study nature, and can include their "little brothers of the air" and the humblest flower at their feet when they say with Paul, "In God we live and move and have our being."

Tallest and most prolific of bloom among our native lilies, as it is the most variable in color, size, and form, the Turk's Cap, or Turban Lily (L. superbum), sometimes nearly merges its identity into its Canadian sister's. Travellers by rail between New York and Boston know how gorgeous are the low meadows and marshes in July or August, when its clusters of deep yellow, orange, or flame-colored lilies tower above the surrounding vegetation. Like the color of most flowers, theirs intensifies in salt air. Commonly from three to seven lilies appear in a terminal group; but under skilful cultivation even forty will crown the stalk that reaches a height of nine feet where its home suits it perfectly; or maybe only a poor array of dingy yellowish caps top a shrivelled stem when unfavorable conditions prevail. There certainly are times when its specific name seems extravagant.

Red, Wood, Flame, or Philadelphia Lily

\section{Lilium philadelphicum}

Flowers-Erect, tawny, or red-tinted outside; vermilion, or sometimes reddish orange, and spotted with madder brown within; 1 to 5 , on separate peduncles, borne at the summit. Perianth of 6 distinct, spreading, spatulate segments, each narrowed into a claw, and with a nectar groove at its base; 6 stamens; 1 style, the club-shaped stigma 3-lobed. Stem: 1 to $3 \mathrm{ft}$. tall, from a bulb composed of narrow, jointed, fleshy scales. Leaves: In whorls of 3's to 8's, lance-shaped, seated at intervals on the stem.

Preferred Habitat-Dry woods, sandy soil, borders, and thickets.

Flowering Season-June-July. 
Distribution-Northern border of United States, westward to Ontario, south to the Carolinas and West Virginia.

Erect, as if conscious of its striking beauty, this vivid lily lifts a chalice that suggests a trap for catching sunbeams from fiery old Sol. Defiant of his scorching rays in its dry habitat, it neither nods nor droops even during prolonged drought; and yet many people confuse it with the gracefully pendent, swaying bells of the yellow Canada Lily, which will grow in a swamp rather than forego moisture. La, the Celtic for white, from which the family derived its name, makes this bright-hued flower blush to own it. Seedsmen, who export quantities of our superb native lilies to Europe, supply bulbs so cheap that no one should wait four years for flowers from seed, or go without their splendor in our over-conventional gardens.

Yellow Adder's Tongue; Trout Lily; Dog-tooth "Violet"

Erythronium americanum

Flower-Solitary, pale russet yellow, rarely tinged with purple, slightly fragrant, 1 to $2 \mathrm{in.} \mathrm{long,} \mathrm{nodding} \mathrm{from} \mathrm{the} \mathrm{summit} \mathrm{of} \mathrm{a} \mathrm{root-stalk} 6$ to $12 \mathrm{in}$, high, or about as tall as the leaves. Perianth bell-shaped, of 6 petal-like, distinct segments, spreading at tips, dark spotted within; 6 stamens; the club-shaped style with 3 short, stigmatic ridges. Leaves: 2 , unequal, grayish green, mottled and streaked with brown or all green, oblong, 3 to 8 in. long, narrowing into clasping petioles.

Preferred Habitat—Moist open woods and thickets, brooksides.

Flowering Season-March-May.

Distribution-Nova Scotia to Florida, westward to the Mississippi.

Colonies of these dainty little lilies, that so often grow beside leaping brooks where and when the trout hide, justify at least one of their names; but they have nothing in common with the violet or a dog's tooth. Their faint fragrance rather suggests a tulip; and as for the bulb, which in some of the lily-kin has toothlike scales, it is in this case a smooth, egg-shaped corm, producing little round offsets from its base. Much fault is also found with another name on the plea that the curiously mottled and delicately pencilled leaves bring to mind, not a snake's tongue, but its skin, as they surely do. Whoever sees the sharp purplish point of a young plant darting above ground in earliest spring, however, at once sees the fitting application of adder's tongue. But how few recognize their plant friends at all seasons of the year! 
Every one must have noticed the abundance of low-growing spring flowers in deciduous woodlands, where, later in the year, after the leaves overhead cast a heavy shade, so few blossoms are to be found, because their light is seriously diminished. The thrifty adder's tongue, by laying up nourishment in its storeroom underground through the winter, is ready to send its leaves and flower upward to take advantage of the sunlight the still naked trees do not intercept, just as soon as the ground thaws.

\section{Yellow Clintonia}

\section{Clintonia borealis}

Flowers-Straw color or greenish yellow, less than 1 in. long, 3 to 6 nodding on slender pedicels from the summit of a leafless scape 6 to 15 in. tall. Perianth of 6 spreading divisions, the 6 stamens attached; style, 3-lobed. Leaves: Dark, glossy, large, oval to oblong, 2 to 5 (usually 3), sheathing at the base. Fruit: Oval blue berries on upright pedicels.

Preferred Habitat-Moist, rich, cool woods and thickets.

Flowering Season-May-June.

Distribution-From the Carolinas and Wisconsin far northward.

To name canals, bridges, city thoroughfares, booming factory towns after De Witt Clinton seems to many appropriate enough; but why a shy little woodland flower? As fitly might a wee white violet carry down the name of Theodore Roosevelt to posterity! "Gray should not have named the flower from the Governor of New York," complains Thoreau. "What is he to the lovers of flowers in Massachusetts? If named after a man, it must be a man of flowers." So completely has Clinton, the practical man of affairs, obliterated Clinton, the naturalist, from the popular mind, that, were it not for this plant keeping his memory green, we should be in danger of forgetting the weary, overworked governor, fleeing from care to the woods and fields; pursuing in the open air the study which above all others delighted and refreshed him; revealing in every leisure moment a too-often forgotten side of his many-sided greatness.

Wild Spikenard; False Solomon's Seal; Solomon's Zig-zag 
Flowers-White or greenish, small, slightly fragrant, in a densely flowered terminal raceme. Perianth of 6 separate, spreading segments; 6 stamens; 1 pistil. Stem: Simple, somewhat angled, 1 to $3 \mathrm{ft}$. high, scaly below, leafy, and sometimes finely hairy above. Leaves: Alternate and seated along stem, oblong, lance-shaped, 3 to 6 in. long, finely hairy beneath. Rootstock: Thick, fleshy. Fruit: A cluster of aromatic, round, pale red speckled berries.

Preferred Habitat-Moist woods, thickets, hillsides.

Flowering Season-May-July.

Distribution-Nova Scotia to Georgia; westward to Arizona and British Columbia.

As if to offer opportunities for comparison to the confused novice, the true Solomon's Seal and the so-called false species-quite as honest a plant-usually grow near each other. Grace of line, rather than beauty of blossom, gives them both their chief charm. But the feathery plume of greenish-white blossoms that crowns the false Solomon's Seal's somewhat zig-zagged stem is very different from the small, greenish, bell-shaped flowers, usually nodding in pairs along the stem, under the leaves, from the axils of the true Solomon's Seal. Later in summer, when hungry birds wander through the woods with increased families, the Wild Spikenard offers them branching clusters of pale red speckled berries, whereas the former plant feasts them with blue-black fruit.

Hairy, or True, or Twin-flowered Solomon's Seal

Polygonatum biflorum

Flowers-Whitish or yellowish green, tubular, bell-shaped, 1 to 4, but usually 2, drooping on slender peduncles from leaf axils. Perianth 6-lobed at entrance, but not spreading; 6 stamens, the filaments roughened; 1 pistil. Stem: Simple, slender, arching, leafy, 8 in. to $3 \mathrm{ft}$. long. Leaves: Oval, pointed, or lance-shaped, alternate, 2 to $4 \mathrm{in}$. long, seated on stem, pale beneath and softly hairy along veins. Rootstock: Thick, horizontal, jointed, scarred. (Polygonatum = many joints.) Fruit: A blue-black berry.

Preferred Habitat-Woods, thickets, shady banks.

Flowering Season-April-June. 
Distribution-New Brunswick to Florida, westward to Michigan.

From a many-jointed, thick rootstock a single graceful curved stem arises each spring, withers after fruiting, and leaves a round scar, whose outlines suggested to the fanciful man who named the genus the seal of Israel's wise king. Thus one may know the age of a root by its seals, as one tells that of a tree by the rings in its trunk.

\section{Early or Dwarf Wake-Robin}

\section{Trillium nivale}

Flowers-Solitary, pure white, about 1 in. long, on an erect or curved peduncle, from a whorl of 3 leaves at summit of stem. Three spreading, green, narrowly oblong sepals; 3 oval or oblong petals; 6 stamens, the anthers about as long as filaments; 3 slender styles stigmatic along inner side. Stem: 2 to 6 in. high, from a short, tuber-like rootstock. Leaves: 3 in a whorl below the flower, 1 to 2 in. long, broadly oval, rounded at end, on short petioles. Fruit: A 3-lobed reddish berry, about $1 / 2$ in. diameter, the sepals adhering.

Preferred Habitat-Rich, moist woods and thickets.

Flowering Season-March-May.

Distribution-Pennsylvania, westward to Minnesota and Iowa, south to Kentucky.

Only this delicate little flower, as white as the snow it sometimes must push through to reach the sunshine melting the last drifts in the leafless woods, can be said to wake the robins into song; a full chorus of feathered love-makers greets the appearance of the more widely distributed, and therefore better known, species.

By the rule of three all the trilliums, as their name implies, regulate their affairs. Three sepals, three petals, twice three stamens, three styles, a three-celled ovary, the flower growing out from a whorl of three leaves, make the naming of wakerobins a simple matter to the novice.

One of the most chastely beautiful of our native wild flowers-so lovely that many shady nooks in English rock-gardens and ferneries contain imported clumps of the vigorous plant-is the Large-flowered Wake-Robin, or White 
Wood Lily (T. grandiflorum). Under favorable conditions the waxy, thin, white, or occasionally pink, strongly veined petals may exceed two inches; and in Michigan a monstrous form has been found. The broadly rhombic leaves, tapering to a point, and lacking petioles, are seated in the usual whorl of three, at the summit of the stem, which may attain a foot and a half in height; from the centre the decorative flower arises on a long peduncle.

Certainly the commonest trillium in the East, although it thrives as far westward as Ontario and Missouri, and south to Georgia, is the Nodding Wake-Robin (T. cernuum), whose white or pinkish flower droops from its peduncle until it is all but hidden under the whorl of broadly rhombic, tapering leaves. The wavy margined petals, about as long as the sepals - that is to say, half an inch long or overcurve backward at maturity. One finds the plant in bloom from April to June, according to the climate of its long range.

Perhaps the most strikingly beautiful member of the tribe is the Painted Trillium (T. undulatum or T. erythrocarpum). At the summit of the slender stem, rising perhaps only eight inches, or maybe twice as high, this charming flower spreads its long, wavy-edged, waxy-white petals veined and striped with deep pink or wine color. The large ovate leaves, long-tapering to a point, are rounded at the base into short petioles. The rounded, three-angled, bright red, shining berry is seated in the persistent calyx. With the same range as the nodding trillium's, the Painted Wake-Robin comes into bloom nearly a month later-in May and June-when all the birds are not only wide awake, but have finished courting, and are busily engaged in the most serious business of life.

Purple Trillium, Ill-scented Wake-Robin, or Birth-root

\section{Trillium erectum}

Flowers-Solitary, dark, dull purple, or purplish red; rarely greenish, white, or pinkish; on erect or slightly inclined footstalk. Calyx of 3 spreading sepals, 1 to 1-1/2 in. long, or about length of 3 pointed, oval petals; stamens, 6; anthers longer than filaments; pistil spreading into 3 short, recurved stigmas. Stem: Stout, 8 to 16 in. high, from tuber-like rootstock. Leaves: In a whorl of 3; broadly ovate, abruptly pointed, netted-veined. Fruit: A 6-angled, ovate, reddish berry.

Preferred Habitat-Rich, moist woods. 
Flowering Season-April-June.

Distribution-Nova Scotia westward to Manitoba, southward to North Carolina and Missouri.

Some weeks after the jubilant, alert robins have returned from the South, the Purple Trillium unfurls its unattractive, carrion-scented flower. In the variable colors found in different regions, one can almost trace its evolution from green, white, and red to purple, which, we are told, is the course all flowers must follow to attain to blue. The white and pink forms, however attractive to the eye, are never more agreeable to the nose than the reddish-purple ones. Bees and butterflies, with delicate appreciation of color and fragrance, let the blossom alone, since it secretes no nectar; and one would naturally infer either that it can fertilize itself without insect aid - a theory which closer study of its organs goes far to disprove-or that the carrion-scent, so repellent to us, is in itself an attraction to certain insects needful for cross-pollination. Which are they? Beetles have been observed crawling over the flower, but without effecting any methodical result. One inclines to accept Mr. Clarence M. Weed's theory of special adaptation to the common green flesh-flies (Lucilia carnicina), which would naturally be attracted to a flower resembling in color and odor a raw beefsteak of uncertain age. These little creatures, seen in every butcher shop throughout the summer, the flower furnishes with a free lunch of pollen in consideration of the transportation of a few grains to another blossom. Absence of the usual floral attractions gives the carrion flies a practical monopoly of the pollen food, which no doubt tastes as it smells.

The Sessile-flowered Wake-Robin (T. sessile), whose dark purple, purplish-red, or greenish blossom, narrower of sepal and petals than the preceding, is seated in a whorl of three egg-shaped, sometimes blotched, leaves, possesses a rather pleasant odor; nevertheless, it seems to have no great attraction for insects. The stigmas, which are very large, almost touch the anthers surrounding them; therefore the beetles which one frequently sees crawling over them to feed on the pollen so jar them, no doubt, as to self-fertilize the flower; but it is scarcely probable these slow crawlers often transfer the grains from one blossom to another. A degraded flower like this has little need of color and perfume, one would suppose; yet it may be even now slowly perfecting its way toward an ideal of which we see a part only complete. In deep, rich, moist woods and thickets the sessile trillium blooms in April or May, from Pennsylvania, Ohio, and Minnesota southward nearly to the Gulf.

Carrion-flower

Smilax herbacea 
Flowers-Carrion-scented, yellowish-green, 15 to 80 small, 6-parted ones clustered in an umbel on a long peduncle. Stem: Smooth, unarmed, climbing with the help of tendril-like appendages from the base of leafstalks. Leaves: Eggshaped, heart-shaped, or rounded, pointed tipped, parallel-nerved, petioled. Fruit: Bluish-black berries.

Preferred Habitat-Moist soil, thickets, woods, roadside fences.

Flowering Season-April-June.

Distribution-Northern Canada to the Gulf states, westward to Nebraska.

"It would be safe to say," says John Burroughs, "that there is a species of smilax with an unsavory name, that the bee does not visit, herbacea. The production of this plant is a curious freak of nature.... It would be a cruel joke to offer it to any person not acquainted with it, to smell. It is like the vent of a charnel-house." (Thoreau compared its odor to that of a dead rat in a wall!) "It is first cousin to the trilliums, among the prettiest of our native wild flowers," continues Burroughs, "and the same bad blood crops out in the Purple Trillium or Birth-root."

Strange that so close an observer as Burroughs or Thoreau should not have credited the carrion-flower with being something more intelligent than a mere repellent freak! Like the Purple Trillium, it has deliberately adapted itself to please its benefactors, the little green flesh-flies so commonly seen about untidy butcher shops in summer. 


\section{AMARYLLIS FAMILY (Amaryllidaceae)}

\section{Yellow Star-grass}

Hypoxis hirsuta (H. erecta)

Flowers-Bright yellow within, greenish and hairy outside, about $1 / 2$ in. across, 6-parted; the perianth divisions spreading, narrowly oblong; a few flowers at the summit of a rough, hairy scape 2 to 6 in. high. Leaves: All from an egg-shaped corm; mostly longer than scapes, slender, grass-like, more or less hairy.

Preferred Habitat—Dry, open woods, prairies, grassy waste places, fields.

Flowering Season-May-October.

Distribution-From Maine far westward, and south to the Gulf of Mexico.

Usually only one of these little blossoms in a cluster on each plant opens at a time; but that one peers upward so brightly from among the grass it cannot well be overlooked. Sitting in a meadow sprinkled over with these yellow stars, we see coming to them many small bees-chiefly Halictus - to gather pollen for their unhatched babies' bread. Of course they do not carry all the pollen to their tunnelled nurseries; some must often be rubbed off on the sticky pistil tip in the centre of other stars. The stamens radiate, that self-fertilization need not take place except as a last extremity. Visitors failing, the little flower closes, bringing its pollen-laden anthers in contact with its own stigma. 


\section{IRIS FAMILY (Iridaceae)}

Larger Blue Flag; Blue Iris; Fleur-de-lis; Flower-de-luce

Iris versicolor

Flowers-Several, 2 to 3 in. long, violet-blue variegated with yellow, green, or white, and purple veined. Six divisions of the perianth: 3 outer ones spreading, recurved; 1 of them bearded, much longer and wider than the 3 erect inner divisions; all united into a short tube. Three stamens under 3 overhanging petal-like divisions of the style, notched at end; under each notch is a thin plate, smooth on one side, rough and moist (stigma) on side turned away from anther. Stem: 2 to $3 \mathrm{ft}$. high, stout, straight, almost circular, sometimes branching above. Leaves: Erect, sword-shaped, shorter than stem, somewhat hoary, from $1 / 2$ to $1 \mathrm{in}$. wide, folded, and in a compact flat cluster at base; bracts usually longer than stem of flower. Fruit: Oblong capsule, not prominently 3-lobed, and with 2 rows of round, flat seeds closely packed in each cell. Rootstock: Creeping, horizontal, fleshy.

Preferred Habitat-Marshes, wet meadows.

Flowering Season-May-July.

Distribution-Newfoundland and Manitoba to Arkansas and Florida.

This gorgeous flower is thought by scientists to be all that it is for the bees' benefit, which, of course, is its own also. Abundant moisture, from which to manu- 
facture nectar-a prime necessity with most irises - certainly is for our blue flag. The large, showy blossom cannot but attract the passing bee, whose favorite color (according to Sir John Lubbock) it waves. The bee alights on the convenient, spreading platform, and, guided by the dark veining and golden lines leading to the nectar, sips the delectable fluid shortly to be changed to honey. Now, as he raises his head and withdraws it from the nectary, he must rub it against the pollen-laden anther above, and some of the pollen necessarily falls on the visitor. As the sticky side of the plate (stigma), just under the petal-like division of the style, faces away from the anther, which is below it in any case, the flower is marvellously guarded against fertilization from its own pollen. The bee, flying off to another iris, must first brush past the projecting lip of the overarching style, and leave on the stigmatic outer surface of the plate some of the pollen brought from the first flower, before reaching the nectary. Thus cross-fertilization is effected; and Darwin has shown how necessary this is to insure the most vigorous and beautiful offspring. Without this wonderful adaptation of the flower to the requirements of its insect friends, and of the insect to the needs of the flower, both must perish; the former from hunger, the latter because unable to perpetuate its race. And yet man has greedily appropriated all the beauties of the floral kingdom as designed for his sole delight!

"The fleur-de-lys, which is the flower of chivalry," says Ruskin, "has a sword for its leaf and a lily for its heart." When that young and pious Crusader, Louis VII, adopted it for the emblem of his house, spelling was scarcely an exact science, and the fleur-de-Louis soon became corrupted into its present form. Doubtless the royal flower was the white iris, and as $\mathrm{li}$ is the Celtic for white, there is room for another theory as to the origin of the name. It is our far more regal looking, but truly democratic blossom, jostling its fellows in the marshes, that is indeed "born in the purple."

The name iris, meaning a deified rainbow, which was given this group of plants by the ancients, shows a fine appreciation of their superb coloring, their ethereal texture, and the evanescent beauty of the blossom.

Blackberry Lily

Belamcanda chinensis (Pardanthus chinensis)

Flowers-Deep orange color, speckled irregularly with crimson and purple within $($ Pardos = leopard; anthos = flower); borne in terminal, forked clusters. Perianth of 6 oblong, petal-like, spreading divisions; 6 stamens with linear anthers; style thickest above, with 3 branches. Stem: $1-1 / 2$ to $4 \mathrm{ft}$. tall, leafy. Leaves: Like the 
iris; erect, folded blades, 8 to 10 in. long. Fruit: Resembling a blackberry; an erect mass of round, black, fleshy seeds, at first concealed in a fig-shaped capsule, whose 3 valves curve backward, and finally drop off.

Preferred Habitat—Roadsides and hills.

Flowering Season-June-July.

Distribution-Connecticut to Georgia, westward to Indiana and Missouri. How many beautiful foreign flowers, commonly grown in our gardens here, might soon become naturalized Americans were we only generous enough to lift a few plants, scatter a few seeds over our fences into the fields and roadsides- to raise the bars of their prison, as it were, and let them free! Many have run away, to be sure. Once across the wide Atlantic, or wider Pacific, their passage paid (not sneaking in among the ballast like the more fortunate weeds), some are doomed to stay in prim, rigidly cultivated flower beds forever; ochers, only until a chance to bolt for freedom presents itself, and away they go. Lucky are they if every flower they produce is not picked before a single seed can be set.

This Blackberry Lily of gorgeous hue originally came from China. Escaping from gardens here and there, it was first reported as a wild flower at East Rock, Connecticut; other groups of vagabonds were met marching along the roadsides on Long Island; near Suffern, New York; then farther southward and westward, until it has already attained a very respectable range. Every plant has some good device for sending its offspring away from home to found new colonies, if man would but let it alone. Better still, give the eager travellers a lift!

Pointed Blue-eyed Grass; Eye-bright; Blue Star

Sisyrinchium angustifolium

Flowers-From blue to purple, with a yellow centre; a Western variety, white; usually several buds at the end of the stem, between 2 erect unequal bracts; about $1 / 2$ in. across; perianth of 6 spreading divisions, each pointed with a bristle from a notch; stamens 3, the filaments united to above the middle; pistil 1, its tip 3cleft. Stem: 3 to 14 in. tall, pale hoary green, flat, rigid, 2-edged. Leaves: Grasslike, pale, rigid, mostly from base. Fruit: 3-celled capsule, nearly globose.

Preferred Habitat-Moist fields and meadows.

Flowering Season-May-August. 
Distribution-Newfoundland to British Columbia, from eastern slope of Rocky Mountains to Atlantic, south to Virginia and Kansas.

Only for a day, and that must be a bright one, will this "little sister of the stately blue flag" open its eyes, to close them in indignation on being picked; nor will any coaxing but the sunshine's induce it to open them again in water, immediately after. The dainty flower, growing in dense tufts, makes up in numbers what it lacks in size and lasting power, flecking our meadows with purplish ultramarine blue on a sunny June morning. Later in the day, apparently there are no blossoms there, for all are tightly closed, never to bloom again. New buds will unfold to tinge the field on the morrow.

Usually three buds nod from between a pair of bracts, the lower one of which may be twice the length of the upper one; but only one flower opens at a time. Slight variations in this plant have been considered sufficient to differentiate several species formerly included by Gray and other American botanists under the name of S. Bermudiana. 


\section{ORCHIS FAMILY (Orchidaceae)}

Large Yellow Lady's Slipper; Whippoorwill's Shoe; Yellow Moccasin Flower

Cypripedium pubescens (C. hirsutum)

Flower-Solitary, large, showy, borne at the top of a leafy stem 1 to $2 \mathrm{ft}$. high. Sepals 3, 2 of them united, greenish or yellowish, striped with purple or dull red, very long, narrow; 2 petals, brown, narrower, twisting; the third an inflated sac, open at the top, 1 to 2 in. long, pale yellow, purple lined; white hairs within; sterile stamen triangular; stigma thick. Leaves: Oval or elliptic, pointed, 3 to 5 in. long, parallel-nerved, sheathing.

Preferred Habitat-Moist or boggy woods and thickets; hilly ground.

Flowering Season-May-July.

Distribution-Nova Scotia to Alabama, westward to Minnesota and Nebraska.

Swinging outward from a leaf-clasped stem, this orchid attracts us by its flaunted beauty and decorative form from tip to root, not less than the aesthetic little bees for which its adornment and mechanism are so marvellously adapted. Doubtless the heavy, oily odor is an additional attraction to them.

These common orchids, which are not at all difficult to naturalize in a welldrained, shady spot in the garden, should be lifted with a good ball of earth and plenty of leaf-mould immediately after flowering. 
The similar Small Yellow Lady's Slipper (C. parviflorum), a delicately fragrant orchid about half the size of its big sister, has a brighter yellow pouch, and occasionally its sepals and petals are purplish. As they usually grow in the same localities, and have the same blooming season, opportunities for comparison are not lacking. This fairer, sweeter, little orchid roams westward as far as the State of Washington.

Moccasin Flower; Pink, Venus', or Stemless Lady's Slipper

\section{Cypripedium acaule}

Flowers-Fragrant, solitary, large, showy, drooping from end of scape, 6 to $12 \mathrm{in.}$ high. Sepals lance-shaped, spreading, greenish purple, 2 in. long or less; petals narrower and longer than sepals. Lip an inflated sac, often more than 2 in. long, slit down the middle, and folded inwardly above, pale magenta, veined with darker pink; upper part of interior crested with long white hairs. Stamens united with style into unsymmetrical declined column, bearing an anther on either side, and a dilated triangular petal-like sterile stamen above, arching over the broad concave stigma. Leaves: 2, from the base; elliptic, thick, 6 to $8 \mathrm{in.} \mathrm{long.}$

Preferred Habitat-Deep, rocky, or sandy woods.

Flowering Season-May-June.

Distribution-Canada southward to North Carolina, westward to Minnesota and Kentucky.

Because most people cannot forbear picking this exquisite flower that seems too beautiful to be found outside a millionaire's hothouse, it is becoming rarer every year, until the finding of one in the deep forest, where it must now hide, has become the event of a day's walk. Once it was the commonest of the orchids.

"Cross-fertilization," says Darwin, "results in offspring which vanquish the offspring of self-fertilization in the struggle for existence." This has been the motto of the orchid family for ages. No group of plants has taken more elaborate precautions against self-pollination or developed more elaborate and ingenious mechanism to compel insects to transfer their pollen than this.

The fissure down the front of the Pink Lady's Slipper is not so wide but that a bee must use some force to push against its elastic sloping sides and enter the large 
banquet chamber where he finds generous entertainment secreted among the fine white hairs in the upper part. Presently he has feasted enough. Now one can hear him buzzing about inside, trying to find a way out of the trap. Toward the two little gleams of light through apertures at the end of a passage beyond the nectary hairs he at length finds his way. Narrower and narrower grows the passage until it would seem as if he could never struggle through; nor can he until his back has rubbed along the sticky, overhanging stigma, which is furnished with minute, rigid, sharply pointed papillae, all directed forward, and placed there for the express purpose of combing out the pollen he has brought from another flower on his back or head. The imported pollen having been safely removed, he still has to struggle on toward freedom through one of the narrow openings, where an anther almost blocks his way.

As he works outward, this anther, drawn downward on its hinge, plasters his back with yellow granular pollen as a parting gift, and away he flies to another lady's slipper to have it combed out by the sticky stizma as described above. The smallest bees can squeeze through the passage without paying toll. To those of the Andrena and Halictus tribe the flower is evidently best adapted. Sometimes the largest bumblebees, either unable or unwilling to get out by the legitimate route, bite their way to liberty. Mutilated sacs are not uncommon. But when unable to get out by fair means, and too bewildered to escape by foul, the large bee must sometimes perish miserably in his gorgeous prison.

Showy, Gay, or Spring Orchis

Orchis spectabilis

Flowers-Purplish pink, of deeper and lighter shade, the lower lip white, and thick of texture; from 3 to 6 on a spike; fragrant. Sepals pointed, united, arching above the converging petals, and resembling a hood; lip large, spreading, prolonged into a spur, which is largest at the tip and as long as the twisted footstem. Stem: 4 to 12 in. high, thick, fleshy, 5-sided. Leaves: 2, large, broadly ovate, glossy green, silvery on underside, rising from a few scales from root. Fruit: A sharply angled capsule, 1 in. long.

Preferred Habitat—Rich, moist woods, especially under hemlocks.

Flowering Season-April-June.

Distribution-From New Brunswick and Ontario southward to our Southern states, westward to Nebraska. 
Of the six floral leaves which every orchid, terrestrial or aerial, possesses, one is always peculiar in form, pouch-shaped, or a cornucopia filled with nectar, or a flaunted, fringed banner, or a broad platform for the insect visitors to alight on. Some orchids look to imaginative eyes as if they were masquerading in the disguise of bees, moths, frogs, birds, butterflies. A number of these queer freaks are to be found in Europe. Spring traps, adhesive plasters, and hair-triggers attached to explosive shells of pollen are among the many devices by which orchids compel insects to cross-fertilize them, these flowers as a family showing the most marvellous mechanism adapted to their requirements from insects in the whole floral kingdom. No other blossoms can so well afford to wear magenta, the ugliest shade nature produces, the "lovely rosy purple" of Dutch bulb growers.

Large, or Early, Purple-fringed Orchis

\section{Habenaria fimbriata (H. grandiflora)}

Flowers-Pink-purple and pale lilac, sometimes nearly white; fragrant, alternate, clustered in thick, dense spikes from 3 to 15 in. long. Upper sepal and toothed petals erect; the lip of deepest shade, 1/2 in. long, fan-shaped, 3-parted, fringed half its length, and prolonged at base into slender, long spur; stamen united with style into short column; 2 anther sacs slightly divergent, the hollow between them glutinous, stigmatic. Stem: 1 to $5 \mathrm{ft}$. high, angled, twisted. Leaves: Oval, large, sheathing the stem below; smaller, lance-shaped ones higher up bracts above. Root: Thick, fibrous.

Preferred Habitat-Rich, moist meadows, muddy places, woods.

Flowering Season-June-August.

Distribution-New Brunswick to Ontario; southward to North Carolina, westward to Michigan.

Because of the singular and exquisitely unerring adaptations of orchids as a family to their insect visitors, no group of plants has greater interest for the botanist since Darwin interpreted their marvellous mechanism, and Gray, his instant disciple, revealed the hidden purposes of our native American species, no less wonderfully constructed than the most costly exotic in a millionaire's hothouse.

A glance at the spur of this orchid, one of the handsomest and most striking of its clan, and the heavy perfume of the flower, would seem to indicate that only a 
moth with a long proboscis could reach the nectar secreted at the base of the thread-like passage. Butterflies, attracted by the conspicuous color, sometimes hover about the showy spikes of bloom, but it is probable that, to secure a sip, all but possibly the very largest of them must go to the smaller Purple-fringed Orchis, whose shorter spur holds out a certain prospect of reward; for, in these two cases, as in so many others, the flower's welcome for an insect is in exact proportion to the length of its visitor's tongue. Doubtless it is one of the smaller sphinx moths, such as we see at dusk working about the evening primrose and other flowers deep of chalice, and heavily perfumed to guide visitors to their feast, that is the great Purple-fringed Orchid's benefactor, since the length of its tongue is perfectly adapted to its needs. Attracted by the showy, broad lower petal, his wings ever in rapid motion, the moth proceeds to unroll his proboscis and drain the cup that is frequently an inch and a half deep. Thrusting in his head, either one or both of his large, projecting eyes are pressed against the sticky buttonshaped discs to which the pollen masses are attached by a stalk, and as he raises his head to depart, feeling that he is caught, he gives a little jerk that detaches them, and away he flies with these still fastened to his eyes.

Even while he is flying to another flower, that is to say, in half a minute, the stalks of the pollen masses bend downward from the perpendicular and slightly toward the centre, or just far enough to require the moth, in thrusting his proboscis into the nectary, to strike the glutinous, sticky stigma. Now, withdrawing his head, either or both of the golden clubs he brought in with him will be left on the precise spot where they will fertilize the flower. Sometimes, but rarely, we catch a butterfly or moth from the smaller or larger purple orchids with a pollen mass attached to his tongue, instead of to his eyes; this is when he does not make his entrance from the exact centre-as in these flowers he is not obliged to do-and in order to reach the nectary his tongue necessarily brushes against one of the sticky anther sacs. The performance may be successfully imitated by thrusting some blunt point about the size of a moth's head, a dull pencil or a knitting-needle, into the flower as an insect would enter. Withdraw the pencil, and one or both of the pollen masses will be found sticking to it, and already automatically changing their attitude. In the case of the large, round-leaved orchis, whose greenish-white flowers are fertilized in a similar manner by the sphinx moth, the anther sacs converge, like little horns; and their change of attitude while they are being carried to fertilize another flower is quite as exquisitely exact.

White-fringed Orchis

Habenaria blephariglottis 
Flowers-Pure white, fragrant, borne on a spike from 3 to 6 in. long. Spur long, slender; oval sepals; smaller petal toothed; the oblong lip deeply fringed. Stem: Slender, 1 to $2 \mathrm{ft}$. high. Leaves: Lance-shaped, parallel-veined, clasping the stem; upper ones smallest.

Preferred Habitat-Peat-bogs and swamps.

Flowering Season-July-August.

Distribution-Northeastern United States and eastern Canada to Newfoundland.

One who selfishly imagines that all the floral beauty of the earth was created for man's sole delight will wonder why a flower so exquisitely beautiful as this dainty little orchid should be hidden in inaccessible peat-bogs, where overshoes and tempers get lost with deplorable frequency, and the water-snake and bittern mock at man's intrusion of their realm by the ease with which they move away from him. Not for man, but for the bee, the moth, and the butterfly, are orchids where they are and what they are.

Yellow-fringed Orchis

\section{Habenaria ciliaris}

Flowers-Bright yellow or orange, borne in a showy, closely set, oblong spike, 3 to 6 in. long. The lip of each flower copiously fringed; the slender spur 1 to $1-1 / 2$ in. long; similar to White-fringed Orchis (see above); and between the two, intermediate pale yellow hybrids may be found. Stem: Slender, leafy, 1 to $2-1 / 2$ feet high. Leaves: Lance-shaped, clasping.

Preferred Habitat-Moist meadows and sandy bogs.

Flowering Season--July-August.

Distribution-Vermont to Florida; Ontario to Texas.

Where this brilliant, beautiful orchid and its lovely white sister grow together in the bog-which cannot be through a very wide range, since one is common northward, where the other is rare, and vice versa-the Yellow-fringed Orchis will be found blooming a few days later. In general structure the plants closely resemble each other. 
From Ontario and the Mississippi eastward, and southward to the Gulf, the Tubercled or Small Pale Green Orchis (H. flava) lifts a spire of inconspicuous greenish-yellow flowers, more attractive to the eye of the structural botanist than to the aesthete. It blooms in moist places, as most orchids do, since water with which to manufacture nectar enough to fill their deep spurs is a prime necessity. Orchids have arrived at that pinnacle of achievement that it is impossible for them to fertilize themselves. More than that, some are absolutely sterile to their own pollen when it is applied to their stigmas artificially! With insect aid, however, a single plant has produced more than $1,000,700$ seeds. No wonder, then, that as a family, they have adopted the most marvellous blandishments and mechanism in the whole floral kingdom to secure the visits of that special insect to which each is adapted, and, having secured him, to compel him unwittingly to do their bidding. In the steaming tropical jungles, where vegetation is luxuriant to the point of suffocation, and where insect life swarms in myriads undreamed of here, we can see the best of reasons for orchids mounting into trees and living on air to escape strangulation on the ground, and for donning larger and more gorgeous apparel to attract attention in the fierce competition for insect trade waged about them. Here, where the struggle for survival is incomparably easier, we have terrestrial orchids, small, and quietly clad, for the most part.

Calopogon; Grass Pink

Calopogon pulchellus (Limodorum tuberosum)

Flowers-Purplish pink, 1 in. long, 3 to 15 around a long, loose spike. Sepals and petals similar, oval, acute; the lip on upper side of flower is broad at the summit, tapering into a claw, flexible as if hinged, densely bearded on its face with white, yellow, and magenta hairs (Calopogon = beautiful beard). Column below lip (ovary not twisted in this exceptional case); sticky stigma at summit of column, and just below it a 2 -celled anther, each cell containing 2 pollen masses, the grain lightly connected by threads. Scape: 1 to $1-1 / 2 \mathrm{ft}$. high, slender, naked. Leaf: Solitary, long, grass-like, from a round bulb arising from bulb of previous year.

Preferred Habitat-Swamps, cranberry bogs, and low meadows.

Flowering Season-June-July.

Distribution-Newfoundland to Florida, and westward to the Mississippi.

Fortunately this lovely orchid, one of the most interesting of its highly organized family, is far from rare, and where we find the Rose Pogonia and other bog-lov- 
ing relatives growing, the Calopogon usually outnumbers them all. Limodorum translated reads meadow-gift; but we find the flower less frequently in grassy places than those who have waded into its favorite haunts could wish.

Arethusa; Indian Pink

Arethusa bulbosa

Flowers - 1 to 2 in. long, bright purple pink, solitary, violet scented, rising from between a pair of small scales at end of smooth scape from 5 to $10 \mathrm{in.} \mathrm{high.} \mathrm{Lip}$ dropping beneath sepals and petals, broad, rounded, toothed, or fringed, blotched with purple, and with three hairy ridges down its surface. Leaf: Solitary, hidden at first, coming after the flower, but attaining length of 6 in. Root: Bulbous. Fruit: A 6-ribbed capsule, $1 \mathrm{in.}$ long, rarely maturing.

Preferred Habitat-Northern bogs and swamps.

Flowering Season-May-June.

Distribution-From North Carolina and Indiana northward to the Fur Countries.

One flower to a plant, and that one rarely maturing seed; a temptingly beautiful prize which few refrain from carrying home, to have it wither on the way; pursued by that more persistent lover than Alpheus, the orchid-hunter who exports the bulbs to European collectors-little wonder this exquisite orchid is rare, and that from certain of those cranberry bogs of eastern New England, which it formerly brightened with its vivid pink, it has now gone forever. Like Arethusa, the nymph whom Diana changed into a fountain that she might escape from the infatuated river god, Linnaeus fancied this flower a maiden in the midst of a spring bubbling from wet places where presumably none may follow her.

Nodding Ladies' Tresses or Traces

Spiranthes cernua

Flowers - Small, white or yellowish, without a spur, fragrant, nodding or spreading in 3 rows on a cylindrical, slightly twisted spike 4 or 5 in. long. Side sepals free, the upper ones arching, and united with petals; the oblong, spreading lip crinkle-edged, and bearing minute, hairy callosities at base. Stem: 6 in. to $2 \mathrm{ft}$. 
tall, with several pointed, wrapping bracts. Leaves: From or near the base, linear, almost grass-like.

Preferred Habitat-Low meadows, ditches, and swamps.

Flowering Season-July-October.

Distribution-Nova Scotia to the Gulf of Mexico, and westward to the Mississippi.

This last orchid of the season, and perhaps the commonest of its interesting tribe in the eastern United States, at least, bears flowers that, however insignificant in size, are marvellous pieces of mechanism, to which such men as Charles Darwin and Asa Gray have devoted hours of study and, these two men particularly, much correspondence.

Just as a woodpecker begins at the bottom of a tree and taps his way upward, so a bee begins at the lower and older flowers on a spike and works up to the younger ones; a fact on which this little orchid, like many another plant that arranges its blossoms in long racemes, depends. Let us not note for the present what happens in the older flowers, but begin our observations, with the help of a powerful lens, when the bee has alighted on the spreading lip of a newly opened blossom toward the top of the spire. As nectar is already secreted for her in its receptacle, she thrusts her tongue through the channel provided to guide it aright, and by the slight contact with the furrowed rostellum, it splits, and releases a boat-shaped disk standing vertically on its stern in the passage. Within the boat is an extremely sticky cement that hardens almost instantly on exposure to the air. The splitting of the rostellum, curiously enough, never happens without insect aid; but if a bristle or needle be passed over it ever so lightly, a stream of sticky, milky fluid exudes, hardens, and the boat-shaped disk, with poilen masses attached, may be withdrawn on the bristle just as the bee removes them with her tongue. Each pollinium consists of two leaves of pollen united for about half their length in the middle with elastic threads. As the pollinia are attached parallel to the disk, they stick parallel on the bee's tongue, yet she may fold up her proboscis under her head, if she choose, without inconvenience from the pollen masses, or without danger of loosening them. Now, having finished sucking the newly-opened flowers at the top of the spike, away she flies to an older flower at the bottom of another one. Here a marvellous thing has happened. The passage which, when the flower first expanded, scarcely permitted a bristle to pass, has now widened through the automatic downward movement of the column in order to expose the stigmatic surfaces to contact with the pollen masses brought by the bee. Without 
the bee's help this orchid, with a host of other flowers, must disappear from the face of the earth. So very many species which have lost the power to fertilize themselves now depend absolutely on these little pollen carriers, it is safe to say that, should the bees perish, one half our flora would be exterminated with them. On the slight downward movement of the column in the ladies' tresses, then, as well as on the bee's ministrations, the fertilization of the flower absolutely depends. "If the stigma of the lowest flower has already been fully fertilized," says Darwin, "little or no pollen will be left on its dried surface; but on the next succeeding flower, of which the stigma is adhesive, large sheets of pollen will be left. Then as soon as the bee arrives near the summit of the spike she will withdraw fresh pollinia, will fly to the lower flowers on another plant, and fertilize them; and thus, as she goes her rounds and adds to her store of honey, she continually fertilizes fresh flowers and perpetuates the race of autumnal spiranthes, which will yield honey to future generations of bees." 


\section{BUCKWHEAT FAMILY (Polygonaceae)}

Common Persicaria, Pink Knotweed, or Jointweed; Smartweed

Polygonum pennsylvanicum

Flowers-Very small, pink, collected in terminal, dense, narrow obtuse spikes, 1 to 2 in. long. Calyx pink or greenish, 5-parted, like petals; no corolla; stamens 8 or less; style 2-parted. Stem: 1 to $3 \mathrm{ft}$. high, simple or branched; often partly red, the joints swollen and sheathed; the branches above, and peduncles glandular. Leaves: Oblong, lance-shaped, entire edged, 2 to 11 in. long, with stout midrib, sharply tapering at tip, rounded into short petioles below.

Preferred Habitat-Waste places, roadsides, moist soil.

Flowering Season-July-October.

Distribution-Nova Scotia to the Gulf of Mexico; westward to Texas and Minnesota.

Everywhere we meet this commonest of plants or some of its similar kin, the erect pink spikes brightening roadsides, rubbish heaps, fields, and waste places, from midsummer to frost. The little flowers, which open without method anywhere on the spike they choose, attract many insects, the smaller bees (Andrena) conspicuous among the host. As the spreading divisions of the perianth make nectar-stealing all too easy for ants and other crawlers that would not come in contact with anthers and stigma where they enter a flower near its base, most buckwheat plants 
whose blossoms secrete sweets protect themselves from theft by coating the upper stems with glandular hairs that effectually discourage the pilferers. Shortly after fertilization, the little rounded, flat-sided fruit begins to form inside the persistent pink calyx. At any time the spike-like racemes contain more bright pink buds and shining seeds than flowers. Familiarity alone breeds contempt for this plant, that certainly possesses much beauty. The troublesome and wide-ranging weed called lady's thumb is a near relative. 


\section{POKEWEED FAMILY (Phytolaccaceae)}

Pokeweed; Scoke; Pigeon-berry; Ink-berry; Garget

Phytolacca decandra

Flowers-White, with a green centre, pink tinted outside, about $1 / 4 \mathrm{in}$. across, in bracted racemes 2 to $8 \mathrm{in}$. long. Calyx of 4 or 5 rounded persistent sepals, simulating petals; no corolla; 10 short stamens; 10-celled ovary, green, conspicuous; styles curved. Stem: Stout, pithy, erect, branching, reddening toward the end of summer, 4 to $10 \mathrm{ft}$. tall, from a large, perennial, poisonous root. Leaves: Alternate, petioled, oblong to lance-shaped, tapering at both ends, 8 to 12 in. long. Fruit: Very juicy, dark purplish berries, hanging in long clusters from reddened footstalks; ripe, August-October.

Preferred Habitat—Roadsides, thickets, field borders, and waste soil, especially in burnt-over districts.

Flowering Season-June-October

Distribution-Maine and Ontario to Florida and Texas.

When the Pokeweed is "all on fire with ripeness," as Thoreau said; when the stout vigorous stem (which he coveted for a cane), the large leaves, and even the footstalks, take on splendid tints of crimson lake, and the dark berries hang heavy with juice in the thickets, then the birds, with increased hungry families, gather in flocks as a preliminary step to travelling southward. Has the brilliant, strong- 
scented plant no ulterior motive in thus attracting their attention at this particular time? Surely! Robins, flickers, and downy woodpeckers, chewinks and rosebreasted grosbeaks, among other feathered agents, may be detected in the act of gormandizing on the fruit, whose undigested seeds they will disperse far and wide. Their droppings form the best of fertilizers for young seedlings; therefore the plants which depend on birds to distribute seeds, as most berry-bearers do, send their children abroad to found new colonies, well equipped for a vigorous start in life. What a hideous mockery to continue to call this fruit the Pigeon-berry, when the exquisite bird whose favorite food it once was, has been annihilated from this land of liberty by the fowler's net! And yet flocks of wild pigeons, containing not thousands but millions of birds, nested here even thirty years ago. When the market became glutted with them, they were fed to hogs in the West!

Children, and some grown-ups, find the deep magenta juice of the Ink-berry useful. Notwithstanding the poisonous properties of the root, in some sections the young shoots are boiled and eaten like asparagus, evidently with no disastrous consequences. 


\section{PINK FAMILY (Caryophyllaceae)}

\section{Common Chickweed}

Stellaria media (Alsine media)

Flowers-Small, white, on slender pedicels from leaf axils, also in terminal clusters. Calyx (usually) of 5 sepals, much longer than the 5 (usually) 2-parted petals; 2-10 stamens; 3 or 4 styles. Stem: Weak, branched, tufted, leafy, 4 to 6 in. long, a hairy fringe on one side. Leaves: Opposite, actually oval, lower ones petioled, upper ones seated on stem.

Preferred Habitat-Moist, shady soil; woods; meadows.

Flowering Season-Throughout the year.

Distribution-Almost universal.

The sole use man has discovered for this often pestiferous weed with which nature carpets moist soil the world around is to feed caged song-birds. What is the secret of the insignificant little plant's triumphal progress? Like most immigrants that have undergone ages of selective struggle in the Old World, it successfully competes with our native blossoms by readily adjusting itself to new conditions filling places unoccupied, and chiefly by prolonging its season of bloom beyond theirs, to get relief from the pressure of competition for insect trade in the busy season. Except during the most cruel frosts, there is scarcely a day in the year when we may not find the little star-like chickweed flowers. 
Corn Cockle; Corn Rose; Corn or Red Campion; Crown-of-the-Field

Agrostemma Githago

Flowers-Magenta or bright purplish crimson, 1 to $3 \mathrm{in.}$ broad, solitary at end of long, stout footstem; 5 lobes of calyx leaf-like, very long and narrow, exceeding petals. Corolla of 5 broad, rounded petals; 10 stamens; 5 styles alternating with calyx lobes, opposite petals. Stem,: 1 to $3 \mathrm{ft}$. high, erect, with few or no branches, leafy, the plant covered with fine white hairs. Leaves: Opposite, seated on stem, long, narrow, pointed, erect. Fruit: a 1-celled, many-seeded capsule.

Preferred Habitat-Wheat and other grain fields; dry, waste places.

Flowering Season-July-September.

Distribution-United States at large; most common in Central and Western states. Also in Europe and Asia.

"Allons! allons! sow'd cockle, reap'd no corn," exclaims Byron in "Love's Labor's Lost." Evidently the farmers even in Shakespeare's day counted this brilliant blossom the pest it has become in many of our own grain fields just as it was in ancient times, when Job, after solemnly protesting his righteousness, called on his own land to bear record against him if his words were false. "Let thistles grow instead of wheat, and cockle instead of barley," he cried, according to James the First's translators; but the "noisome weeds" of the original text seem to indicate that these good men were more anxious to give the English people an adequate conception of Job's willingness to suffer for his honor's sake than to translate literally. Possibly the cockle grew in Southern Asia in Job's time: to-day its range is north.

\section{Starry Campion}

Silene stellata

Flowers-White, about $1 / 2 \mathrm{in}$. broad or over, loosely clustered in a showy, pyramidal panicle. Calyx bell-shaped, swollen, 5-toothed, sticky; 5 fringed and clawed petals; 10 long, exserted stamens; 3 styles. Stem: Erect, leafy, 2 to $3-1 / 2 \mathrm{ft}$. tall, rough-hairy. Leaves: Oval, tapering to a point, 2 to $4 \mathrm{in}$. long, seated in whorls of 4 around stem, or loose ones opposite. 
Preferred Habitat-Woods, shady banks.

Flowering Season-June-August.

Distribution-Rhode Island westward to Mississippi, south to the Carolinas and Arkansas.

Feathery white panicles of the Starry Campion, whose protruding stamens and fringed petals give it a certain fleeciness, are dainty enough for spring; by midsummer we expect plants of ranker growth and more gaudy flowers. To save the nectar in each deep tube for the moths and butterflies which cross-fertilize all this tribe of night and day blossoms, most of them-and the campions are notorious examples-spread their calices, and some their pedicels as well, with a sticky substance to entrap little crawling pilferers. Although a popular name for the genus is catchfly, it is usually the ant that is glued to the viscid parts, for the fly that moves through the air alights directly on the flower it is too short-lipped to suck. An ant catching its feet on the miniature lime-twig, at first raises one foot after another and draws it through its mouth, hoping to rid it of the sticky stuff, but only with the result of gluing up its head and other parts of the body. In ten minutes all the pathetic struggles are ended. Let no one guilty of torturing flies to death on sticky paper condemn the Silenes!

Wild Pink or Catchfly

Silene pennsylvanica (S. caroliniana)

Flowers-Rose pink, deep or very pale; about 1 inch broad, on slender footstalks, in terminal clusters. Calyx tubular, 5-toothed, much enlarged in fruit, sticky; 5 petals with claws enclosed in calyx, wedge-shaped above, slightly notched. Stamens 10; pistil with 3 styles. Stem: 4 to 10 in. high, hairy, sticky above, growing in tufts. Leaves: Basal ones spatulate; 2 or 3 pairs of lance-shaped, smaller leaves seated on stem.

Preferred Habitat-Dry, gravelly, sandy, or rocky soil.

Flowering Season-April-June.

Distribution-New England, south to Georgia, westward to Kentucky.

Fresh, dainty, and innocent-looking as Spring herself are these bright flowers. Alas, for the tiny creatures that try to climb up the rosy tufts to pilfer nectar, they 
and their relatives are not so innocent as they appear! While the little crawlers are almost within reach of the cup of sweets, their feet are gummed to the viscid matter that coats it, and here their struggles end as flies' do on sticky fly-paper, or birds' on limed twigs. A naturalist counted sixty-two little corpses on the sticky stem of a single pink. All this tragedy to protect a little nectar for the butterflies which, in sipping it, transfer the pollen from one flower to another, and so help them to produce the most beautiful and robust offspring.

Soapwort; Bouncing Bet; Hedge Pink; Bruisewort; Old Maid's Pink; Fuller's Herb

\section{Saponaria officinalis}

Flowers-Pink or whitish, fragrant, about 1 inch broad, loosely clustered at end of stem, also sparingly from axils of upper leaves. Calyx tubular, 5-toothed, about $3 / 4$ in. long; 5 petals, the claws inserted in deep tube. Stamens 10 , in 2 sets; 1 pistil with 2 styles. Flowers frequently double. Stem: 1 to $2 \mathrm{ft}$. high, erect, stout, sparingly branched, leafy. Leaves: Opposite, acutely oval, 2 to 3 in. long, about 1 in. wide, 3 to 5 ribbed. Fruit: An oblong capsule, shorter than calyx, opening at top by 4 short teeth or valves.

Preferred Habitat—Roadsides, banks, and waste places.

Flowering Season-June-September.

Distribution-Generally common. Naturalized from Europe.

A stout, buxom, exuberantly healthy lassie among flowers is Bouncing Bet, who long ago escaped from gardens whither she was brought from Europe, and ran wild beyond colonial farms to roadsides, along which she has travelled over nearly our entire area. Underground runners and abundant seed soon form thrifty colonies. This plant, to which our grandmothers ascribed healing virtues, makes a cleansing, soap-like lather when its bruised leaves are agitated in water. 


\section{PURSLANE FAMILY (Portulacaceae)}

Spring Beauty; Claytonia

Claytonia virginica

Flowers-White veined with pink, or all pink, the veinings of deeper shade, on curving, slender pedicels, several borne in a terminal loose raceme, the flowers mostly turned one way (secund). Calyx of 2 ovate sepals; corolla of 5 petals slightly united by their bases; 5 stamens, 1 inserted on base of each petal; the style 3cleft. Stem: Weak, 6 to $12 \mathrm{in.} \mathrm{long,} \mathrm{from} \mathrm{a} \mathrm{deep,} \mathrm{tuberous} \mathrm{root.} \mathrm{Leaves:} \mathrm{Opposite}$ above, linear to lance-shaped, shorter than basal ones, which are 3 to 7 in., long; breadth variable.

Preferred Habitat-Moist woods, open groves, low meadows.

Flowering Season-March-May.

Distribution-Nova Scotia and far westward, south to Georgia and Texas.

Very early in the spring a race is run with the hepatica, arbutus, adder's tongue, bloodroot, squirrel corn, and anemone for the honor of being the earliest wild flower; and although John Burroughs and Doctor Abbot have had the exceptional experience of finding the claytonia even before the hepatica - certainly the earliest spring blossom worthy the name in the Middle and New England states-of course the rank Skunk Cabbage, whose name is snobbishly excluded from the list of fair competitors, has quietly opened dozens of minute florets in its incurved horn before the others have even started. 


\section{WATER-LILY FAMILY (Nymphaeaceae)}

Large Yellow Pond, or Water, Lily; Cow Lily; Spatterdock

Nymphaea advena (Nuphar advena)

Flowers-Yellow or greenish outside, rarely purple tinged, round, depressed, 1 $1 / 2$ to 3-1/2 in. across. Sepals 6 , unequal, concave, thick, fleshy; petals stamenlike, oblong, fleshy, short; stamens very numerous, in 5 to 7 rows; pistil compounded of many carpels, its stigmatic disc pale red or yellow, with 12 to 24 rays. Leaves: Floating, or some immersed, large, thick, sometimes a foot long, eggshaped or oval, with a deep cleft at base, the lobes rounded.

Preferred Habitat-Standing water, ponds, slow streams.

Flowering Season-April-September.

Distribution-Rocky Mountains eastward, south to the Gulf of Mexico, north to Nova Scotia.

Comparisons were ever odious. Because the Yellow Water-lily has the misfortune to claim relationship with the sweet-scented white species must it never receive its just meed of praise? Hiawatha's canoe, let it be remembered,

"Floated on the river

Like a yellow leaf in autumn,

Like a yellow water-lily." 
But even those who admire Longfellow's lines see less beauty in the golden flowerbowls floating among the large, lustrous, leathery leaves.

Sweet-scented White Water-lily; Pond Lily; Water Nymph; Water Cabbage

Castalia odorata (Nymphaea odorata)

Flowers-Pure white or pink tinged, rarely deep pink, solitary, 3 to 8 in. across, deliciously fragrant, floating. Calyx of 4 sepals, green outside; petals of indefinite number, overlapping in many rows, and gradually passing into an indefinite number of stamens; outer row of stamens with petaloid filaments and short anthers, the inner yellow stamens with slender filaments and elongated anthers; carpels of indefinite number, united into a compound pistil, with spreading and projecting stigmas. Leaves: Floating, nearly round, slit at bottom, shining green above, reddish and more or less hairy below, 4 to 12 in. across, attached to petiole at centre of lower surface. Petioles and peduncles round and rubber-like, with 4 main airchannels. Rootstock: (Not true stem) thick, simple or with few branches, very long.

Preferred Habitat-Still water, ponds, lakes, slow streams.

Flowering Season-June-September.

Distribution-Nova Scotia to Gulf of Mexico, and westward to the Mississippi.

Sumptuous queen of our native aquatic plants, of the royal family to which the gigantic Victoria regia of Brazil belongs, and all the lovely rose, lavender, blue, and golden exotic water-lilies in the fountains of our city parks, to her man, beast, and insect pay grateful homage. In Egypt, India, China, Japan, Persia, and Asiatic Russia, how many nillions have bent their heads in adoration of her relative the sacred lotus! From its centre Brahma came forth; Buddha, too, whose symbol is the lotus, first appeared floating on the mystic flower (Nelumbo nelumbo). Happily the lovely pink or white "sacred bean" or "rose-lily" of the Nile, often cultivated here, has been successfully naturalized in ponds about Bordentown, New Jersey, and may be elsewhere. If he who planteth a tree is greater than he who taketh a city, that man should be canonized who introduces the magnificent wild flowers of foreign lands to our area of Nature's garden. 


\section{CROWFOOT FAMILY (Ranunculaceae)}

Common Meadow Buttercup; Tall Crowfoot; Kingcups; Cuckoo Flower; Goldcups; Butter-flowers; Blister-flowers

\section{Ranunculus acris}

Flowers-Bright, shining yellow, about $1 \mathrm{in.}$ across, numerous, terminating long slender footstalks. Calyx of 5 spreading sepals; corolla of 5 petals; yellow stamens and carpels. Stem: Erect, branched above, hairy (sometimes nearly smooth), 2 to 3 feet tall, from fibrous roots. Leaves: In a tuft from the base, long petioled, of 3 to 7 divisions cleft into numerous lobes; stem leaves nearly sessile, distant, 3-parted.

Preferred Habitat—Meadows, fields, roadsides, grassy places.

Flowering Season-May-September.

Distribution-Naturalized from Europe in Canada and the United States; most common North.

What youngster has not held these shining golden flowers under his chin to test his fondness for butter? Dandelions and Marsh Marigolds may reflect their color in his clear skin, too, but the buttercup is every child's favorite. When

$$
\text { "Cuckoo-buds of yellow hue }
$$

Do paint the meadows with delight," 
daisies, pink clover, and waving timothy bear them company here; not the "daisies pied," violets, and lady-smocks of Shakespeare's England. How incomparably beautiful are our own meadows in June! But the glitter of the buttercup, which is as nothing to the glitter of a gold dollar in the eyes of a practical farmer, fills him with wrath when this immigrant takes possession of his pastures. Cattle will not eat the acrid, caustic plant-a sufficient reason for most members of the Ranunculaceae to stoop to the low trick of secreting poisonous or bitter juices. Self-preservation leads a cousin, the garden monk's hood, even to murderous practices. Since children will put everything within reach into their mouths, they should be warned against biting the buttercup's stem and leaves, that are capable of raising blisters. "Beggars use the juice to produce sores upon their skin," says Mrs. Creevy. A designer might employ these exquisitely formed leaves far more profitably.

By having its nourishment thriftily stored up underground all winter, the Bulbous Buttercup (R. bulbosus) is able to steal a march on its fibrous-rooted sister that must accumulate hers all spring; consequently it is first to flower, coming in early May, and lasting through June. It is a low and generally more hairy plant, but closely resembling the tall buttercup in most respects, and, like it, a naturalized European immigrant now thoroughly at home in fields and roadsides in most sections of the United States and Canada.

Commonest of the early buttercups is the Tufted species (R. fascicularis), a little plant seldom a foot high, found in the woods and on rocky hillsides from Texas and Manitoba east to the Atlantic, flowering in April or May. The long-stalked leaves are divided into from three to five parts; the bright yellow flowers, with rather narrow, distant petals, measure about an inch across. They open sparingly, usually only one or two at a time on each plant, to favor pollination from another one.

Scattered patches of the Swamp or Marsh Buttercup (R. septentrionalis) brighten low, rich meadows also with their large satiny yellow flowers, whose place in the botany even the untrained eye knows at sight. The smooth, spreading plant sometimes takes root at the joints of its branches and sends forth runners, but the stems mostly ascend. The large lower mottled leaves are raised well out of the wet, or above the grass, on long petioles. They have three divisions, each lobed and cleft. From Georgia and Kentucky far northward this buttercup blooms from April to July, opening only a few flowers at a time-a method which may make it less showy, but more certain to secure cross-pollination between distinct plants. 


\section{Thalictrum polygamum (T. Cornuti)}

Flowers-Greenish white, the calyx of 4 or 5 sepals, falling early; no petals; numerous white, thread-like, green-tipped stamens, spreading in feathery tufts, borne in large, loose, compound terminal clusters $1 \mathrm{ft}$. long or more. Stem: Stout, erect, 3 to $11 \mathrm{ft}$. high, leafy, branching above. Leaves: Arranged in threes, compounded of various shaped leaflets, the lobes pointed or rounded, dark above, paler below.

Preferred Habitat-Open sunny swamps, beside sluggish water, low meadows.

Flowering Season-July-September

Distribution-Quebec to Florida, westward to Ohio.

Masses of these soft, feathery flowers, towering above the ranker growth of midsummer, possess an unseasonable, ethereal, chaste, spring-like beauty. On some plants the flowers are fleecy white and exquisite; others, again, are dull and coarser. Why is this? Because these are what botanists term polygamous flowers, i.e., some of them are perfect, containing both stamens and pistils; some are male only; others, again, are female. Naturally an insect, like ourselves, is first attracted to the more beautiful male blossoms, the pollen bearers, and of course it transfers the vitalizing dust to the dull pistillate flowers visited later. But the meadowrue, which produces a super-abundance of very light, dry pollen, easily blown by the wind, is often fertilized through that agent also, just as grasses, plantains, sedges, birches, oaks, pines, and all cone-bearing trees are. As might be expected, a plant which has not yet ascended the evolutionary scale high enough to economize its pollen by making insects carry it invariably overtops surrounding vegetation to take advantage of every breeze that blows.

The Early Meadow-rue (T. dioicum), found blooming in open, rocky woods during April and May, from Alabama northward to Labrador, and westward to Missouri, grows only one or two feet high, and, like its tall sister, bears fleecy, greenish-white flowers, the staminate and the pistillate ones on different plants.

Liver-leaf; Hepatica; Liverwort; Round-lobed, or Kidney Liver-leaf; Noble Liverwort; Squirrel Cup 
Hepatica triloba (H. Hepatica)

Flowers-Blue, lavender, purple, pinkish, or white; occasionally, not always, fragrant; 6 to 12 petal-like, colored sepals (not petals, as they appear to be), oval or oblong; numerous stamens, all bearing anthers; pistils numerous; 3 small, sessile leaves, forming an involucre directly under flower, simulate a calyx, for which they might be mistaken. Stems: Spreading from the root, 4 to 6 in. high, a solitary flower or leaf borne at end of each furry stem. Leaves: 3-lobed and rounded, leathery, evergreen; sometimes mottled with, or entirely, reddish purple; spreading on ground, rusty at blooming time, the new leaves appearing after the flowers. Fruit: Usually as many as pistils, dry, 1 -seeded, oblong, sharply pointed, never opening.

Preferred Habitat—Woods; light soil on hillsides.

Flowering Season-December-May.

Distribution-Canada to northern Florida, Manitoba to iowa and Missouri. Most common East.

Even under the snow itself bravely blooms the delicate hepatica, wrapped in fuzzy furs as if to protect its stems and nodding buds from cold. After the plebeian Skunk Cabbage, that ought scarcely to be reckoned among true flowers-and William Hamilton Gibson claimed even before it-it is the first blossom to appear. Winter sunshine, warming the hillsides and edges of woods, opens its eyes.

"Blue as the heaven it gazes at,

Startling the loiterer in the naked groves

With unexpected beauty; for the time

Of blossoms and green leaves is yet afar."

"There are many things left for May," says John Burroughs, "but nothing fairer, if as fair, as the first flower, the hepatica. I find I have never admired this little firstling half enough. When at the maturity of its charms, it is certainly the gem of the woods. What an individuality it has! No two clusters alike; all shades and sizes.... A solitary blue-purple one, fully expanded and rising over the brown leaves or the green moss, its cluster of minute anthers showing like a group of pale stars on its little firmament, is enough to arrest and hold the dullest eye. Then, ... there are individual hepaticas, or individual families among them, that are sweet scented. The gift seems as capricious as the gift of genius in families. You cannot 
tell which the fragrant ones are till you try them. Sometimes it is the large white ones, sometimes the large purple ones, sometimes the small pink ones. The odor is faint, and recalls that of the sweet violets. A correspondent, who seems to have carefully observed these fragrant hepaticas, writes me that this gift of odor is constant in the same plant; that the plant which bears sweet-scented flowers this year will bear them next."

Pollen-feeding flies and female hive bees frequent these blossoms on the first warm days. Whether or not they are rewarded by finding nectar is still a mooted question. They seem to do so.

Wood Anemone; Wind-flower

Anemone quinquefolia

Flowers-Solitary, about $1 \mathrm{in}$, broad, white or delicately tinted with blue or pink outside. Calyx of 4 to 9 oval, petal-like sepals; no petals; stamens and carpels numerous, of indefinite number. Stem: Slender, 4 to $9 \mathrm{in}$. high, from horizontal elongated rootstock. Leaves: On slender petioles, in a whorl of 3 to 5 below the flower, each leaf divided into 3 to 5 variously cut and lobed parts; also a lateappearing leaf from the base.

Preferred Habitat-Woodlands, hillsides, light soil, partial shade.

Flowering Season-April-June.

Distribution-Canada and United States, south to Georgia, west to Rocky Mountains.

According to one poetical Greek tradition, Anemos, the wind, employs these exquisitely delicate little star-like namesakes as heralds of his coming in early spring, while woods and hillsides still lack foliage to break his gusts' rude force. Pliny declared that only the wind could open anemones! Another legend utilized by countless poets pictures Venus wandering through the forests grief-stricken over the death of her youthful lover.

"Alas, the Paphian! fair Adonis slain!

Tears plenteous as his blood she pours amain;

But gentle flowers are born and bloom around

From every drop that falls upon the ground:

Where streams his blood, there blushing springs the rose;

And where a tear has dropped, a wind-flower blows." 
Indeed, in reading the poets ancient and modern for references to this favorite blossom, one realizes as never before the significance of an anthology, literally a flower gathering.

But it is chiefly the European Anemone that is extolled by the poets. Nevertheless our more slender, fragile, paler-leaved, and smaller-flowered species, known, strange to say, by the same scientific name, possesses the greater charm. Doctors, with more prosaic eyes than the poets, find acrid and dangerous juices in the anemone and its kin. Certain European peasants will run past a colony of these pure, innocent blossoms in the belief that the very air is tainted by them. Yet the Romans ceremonially picked the first anemone of the year, with an incantation supposed to guard them against fever. The identical plant that blooms in our woods, which may be found also in Asia, is planted on graves by the Chinese, who call it the "death flower."

Note the clusters of tuberous, dahlia-like roots, the whorl of thin, three-lobed rounded leaflets on long, fine petioles immediately below the smaller pure white or pinkish flowers usually growing in loose clusters, to distinguish the more common Rue Anemone (Anemonella thalictroides or Syndesmon thalictroides or Thalictrum anemonoides) from its cousin the solitary flowered wood or true anemone. Generally there are three blossoms of the Rue Anemone to a cluster, the central one opening first, the side ones only after it has developed its stamens and pistils to prolong the season of bloom and encourage cross-pollination by insects. In the eastern half of the United States, and less abundantly in Canada, these are among the most familiar spring wild flowers. Pick them and they soon wilt miserably; lift the plants early, with a good ball of soil about the roots, and they will unfold their fragile blossoms indoors, bringing with them something of the unspeakable charm of their native woods and hillsides just waking into life.

Virgin’s Bower; Virginia Clematis; Traveller’s Joy; Old Man's Beard

\section{Clematis virginiana}

Flowers-White and greenish, about 1 in. across or less, in loose clusters from the axils. Calyx of 4 or 5 petal-like sepals; no petals; stamens and pistils numerous, of indefinite number; the staminate and pistillate flowers on separate plants; the styles feathery, and more than 1 in. long in fruit. Stem: Climbing, slightly woody. Leaves: Opposite, slender petioled, divided into 3 pointed and 2 widely toothed or lobed leaflets. 
Preferred Habitat-Climbing over woodland borders, thickets, roadside shrubbery, fences, and walls; rich, moist soil.

Flowering Season-July-September.

Distribution-Georgia and Kansas northward; less common beyond the Canadian border.

Charles Darwin, who made so many interesting studies of the power of movement in various plants, devoted special attention to the clematis clan, of which about one hundred species exist; but, alas! none to our traveller's joy, that flings out the right hand of good fellowship to every twig within reach, winds about the sapling in brotherly embrace, drapes a festoon of flowers from shrub to shrub, hooks even its sensitive leafstalks over any available support as it clambers and riots on its lovely way. By rubbing the footstalk of a young leaf with a twig a few times on any side, Darwin found a clematis leaf would bend to that side in the course of a few hours, but return to the straight again if nothing remained on which to hook itself.

In early autumn, when the long, silvery, decorative plumes attached to a ball of seeds form feathery, hoary masses even more fascinating than the flower clusters, the name of old man's beard is most suggestive. These seeds never open, but, when ripe, each is borne on the autumn gales, to sink into the first moist, springy resting place.

Marsh Marigold; Meadow-gowan; American Cowslip

Caltha palustris

Flowers-Bright, shining yellow, 1 to $1-1 / 2$ in. across, a few in terminal and axillary groups. No petals; usually 5 (often more) oval, petal-like sepals; stamens numerous; many pistils (carpels) without styles. Stem: Stout, smooth, hollow, branching, 1 to $2 \mathrm{ft}$. high. Leaves: Mostly from root, rounded, broad, and heartshaped at base, or kidney-shaped, upper ones almost sessile, lower ones on fleshy petioles.

Preferred Habitat—Springy ground, low meadows, swamps, river banks, ditches.

Flowering Season-April-June.

Distribution-Carolina to Iowa, the Rocky Mountains, and very far north. 
Not a true marigold, and even less a cowslip, it is by these names that this flower, which looks most like a buttercup, will continue to be called, in spite of the protests of scientific classifiers. Doubtless the first of these folk-names refers to its use in church festivals during the Middle Ages as one of the blossoms devoted to the Virgin Mary.

\section{"And winking Mary-buds begin \\ To ope their golden eyes,"}

sing the musicians in "Cymbeline." Whoever has seen the watery Avon meadows in April, yellow and twinkling with marsh marigolds when "the lark at heaven's gate sings," appreciates why the commentators incline to identify Shakespeare's Mary-buds with the Caltha of these and our own marshes.

But we know well that not for poets' high-flown rhapsodies but rather for the more welcome hum of bees and flies intent on breakfasting, do these flowers open in the morning sunshine.

Some country people who boil the young plants declare these "greens" are as good as spinach. What sacrilege to reduce crisp, glossy, beautiful leaves like these to a slimy mess in a pot! The tender buds, often used in white sauce as a substitute for capers, probably do not give it the same piquancy where piquancy is surely most needed-on boiled mutton, said to be Queen Victoria's favorite dish. Hawked about the streets in tight bunches, the Marsh Marigold blossoms — with half their yellow sepals already dropped-and the fragrant, pearly, pink arbutus are the most familiar spring wild flowers seen in Eastern cities.

Gold-thread; Canker-root

Coptis trifolia

Flowers-Small, white, solitary, on a slender scape 3 to 6 in. high. Sepals 5 to 7 , petal-like, falling early; petals 5 to 6 , inconspicuous, like club-shaped columns; stamens numerous; carpels few, the stigmatic surfaces curved. Leaves: From the base, long petioled, divided into 3 somewhat fan-shaped, shining, evergreen, sharply toothed leaflets. Rootstock: Thread-like, long, bright yellow, wiry, bitter.

Preferred Habitat-Cool mossy bogs, damp woods.

Flowering Season-May-August. 
Distribution-Maryland and Minnesota northward to circumpolar regions.

Dig up a plant, and the fine, tangled, yellow roots tell why it was given its name. In the good old days when decoctions of any herb that was particularly nauseous were swallowed in the simple faith that virtue resided in them in proportion to their revolting taste, the gold-thread's bitter roots furnished a tea much valued as a spring tonic and as a cure for ulcerated throats and canker-sore mouths of helpless children.

\section{Wild Columbine}

\section{Aquilegia canadensis}

Flower-Red outside, yellow within, irregular, 1 to $2 \mathrm{in}$. long, solitary, nodding from a curved footstalk from the upper leaf axils. Petals 5, funnel-shaped, but quickly narrowing into long, erect, very slender hollow spurs, rounded at the tip and united below by the 5 spreading red sepals, between which the straight spurs ascend; numerous stamens and 5 pistils projecting. Stem: 1 to $2 \mathrm{ft}$. high, branching, soft-hairy or smooth. Leaves: More or less divided, the lobes with rounded teeth; large lower compound leaves on long petioles. Fruit: An erect pod, each of the 5 divisions tipped with a long, sharp beak.

Preferred Habitat-Rocky places, rich woodland.

Flowering Season-April-July.

Distribution-Nova Scotia to the Northwest Territory; southward to the Gulf states. Rocky Mountains.

Although under cultivation the columbine nearly doubles its size, it never has the elfin charm in a conventional garden that it possesses wild in Nature's. Dancing, in red and yellow petticoats, to the rhythm of the breeze along the ledge of overhanging rocks, it coquettes with some Punchinello as if daring him to reach her at his peril. Who is he? Let us sit a while on the rocky ledge and watch for her lovers.

Presently a big muscular bumblebee booms along. Owing to his great strength, an inverted, pendent blossom, from which he must cling upside down, has no more terrors for him than a trapeze for the trained acrobat. His long tongue-if he is one of the largest of our sixty-two species of Bombus_-can suck almost any flower 
unless it is especially adapted to night-flying sphinx moths, but can he drain this? $\mathrm{He}$ is the truest benefactor of the European Columbine (A. vulgaris), whose spurs suggested the talons of an eagle (aquila) to imaginative Linnaeus when he gave this group of plants its generic name. Smaller bumblebees, unable through the shortness of their tongues to feast in a legitimate manner, may be detected nipping holes in the tips of all columbines, where the nectar is secreted, just as they do in larkspurs, Dutchman's breeches, squirrel corn, butter and eggs, and other flowers whose deeply hidden nectaries make dining too difficult for the little rogues. Fragile butterflies, absolutely dependent on nectar, hover near our showy wild columbine with its five tempting horns of plenty, but sail away again, knowing as they do that their weak legs are not calculated to stand the strain of an inverted position from a pendent flower, nor are their tongues adapted to slender tubes unless these may be entered from above. The tongues of both butterflies and moths bend readily only when directed beneath their bodies. It will be noticed that our columbine's funnel-shaped tubes contract just below the point where the nectar is secreted-doubtless to protect it from small bees. When we see the honey-bee or the little wild bees-Halictus chiefly-on the flower, we may know they get pollen only.

Finally a ruby-throated humming bird whirs into sight. Poising before a columbine, and moving around it to drain one spur after another until the five are emptied, he flashes like thought to another group of inverted red cornucopias, visits in turn every flower in the colony, then whirs away quite as suddenly as he came. Probably to him, and no longer to the outgrown bumblebee, has the flower adapted itself. The European species wears blue, the bee's favorite color according to Sir John Lubbock; the nectar hidden in its spurs, which are shorter, stouter, and curved, is accessible only to the largest bumblebees. There are no humming birds in Europe. Our native columbine, on the contrary, has longer, contracted, straight, erect spurs, most easily drained by the ruby-throat which, like Eugene Field, ever delights in "any color at all so long as it's red."

To help make the columbine conspicuous, even the sepals become red; but the flower is yellow within, it is thought to guide visitors to the nectaries. The stamens protrude like a golden tassel. After the anthers pass the still immature stigmas, the pollen of the outer row ripens, ready for removal, while the inner row of undeveloped stamens still acts as a sheath for the stigmas. Owing to the pendent position of the flower, no pollen could fall on the latter in any case. The columbine is too highly organized to tolerate self-fertilization. When all the stamens have discharged their pollen, the styles then elongate; and the feathery stigmas, opening and curving sidewise, bring themselves at the entrance of each of the five cornucopias, just the position the anthers previously occupied. Probably 
even the small bees, collecting pollen only, help carry some from flower to flower; but perhaps the largest bumblebees, and certainly the humming bird, must be regarded as the columbine's legitimate benefactors. Caterpillars of one of the dusky wings (Papilio lucilius) feed on the leaves.

Black Cohosh; Black Snakeroor; Tall Bugbane

\section{Cimicifuga racemosa}

Flowers-Foetid, feathery, white, in an elongated wand-like raceme, 6 in. to $2 \mathrm{ft}$. long, at the end of a stem 3 to $8 \mathrm{ft}$. high. Sepals petal-like, falling early; 4 to 8 small stamen-like petals 2-cleft; stamens very numerous, with long filaments; 1 or 2 sessile pistils with broad stigmas. Leaves: Alternate, on long petioles, thrice compounded of oblong, deeply toothed or cleft leaflets, the end leaflet often again compound. Fruit: Dry oval pods, their seeds in 2 rows.

Preferred Habitat-Rich woods and woodland borders, hillsides.

Flowering Season-June-August.

Distribution-Maine to Georgia, and ivestward from Ontario to Missouri.

Tall white rockets, shooting upward from a mass of large handsome leaves in some heavily shaded midsummer woodland border, cannot fail to impress themselves through more than one sense, for their odor is as disagreeable as the fleecy white blossoms are striking. Obviously such flowers would be most attractive to the carrion and meat flies. Cimicifuga, meaning to drive away bugs, and the old folkname of bugbane restify to a degree of offensiveness to other insects, where the flies' enjoyment begins. As these are the only insects one is likely to see about the fleecy wands, doubtless they are their benefactors. The countless stamens which feed them generously with pollen willingly left for them alone must also dust them well as they crawl about before flying to another foetid lunch.

The close kinship with the baneberries is detected at once on examining one of these flowers. Were the vigorous plant less offensive to the nostrils, many a garden would be proud to own so decorative an addition to the shrubbery border.

White Baneberry; Cohosh

Actaea alba 
Flowers-Small, white, in a terminal oblong raceme. Calyx of 3 to 5 petal-like, early-falling sepals; petals very small, 4 to 10 , spatulate, clawed; stamens white, numerous, longer than petals; 1 pistil with a broad stigma. Stem: Erect, bushy, 1 to $2 \mathrm{ft}$. high. Leaves: Twice or thrice compounded of sharply toothed and pointed, sometimes lobed, leaflets, petioled. Fruit: Clusters of poisonous oval white berries with dark purple spot on end, formed from the pistils. Both pedicels and peduncles much thickened and often red after fruiting.

Preferred Habitat-Cool, shady, moist woods.

Flowering Season-April-June.

Distribution-Nova Scotia to Georgia and far West.

However insignificant the short fuzzy clusters of flowers lifted by this bushy little plant, we cannot fail to name it after it has set those curious white berries with a dark spot on the end, which Mrs. Starr Dana graphically compares to "the china eyes that small children occasionally manage to gouge from their dolls' heads." For generations they have been called "dolls' eyes" in Massachusetts. Especially after these poisonous berries fully ripen and the rigid stems which bear them thicken and redden, we cannot fail to notice them. As the sepals fall early, the white stamens and stigmas are the most conspicuous parts of the flowers. 


\section{BARBERRY FAMILY (Berberidaceae)}

May Apple; Hog Apple; Mandrake; Wild Lemon

Podophyllum peltatum

Flowers-White, solitary, large, unpleasantly scented, nodding from the fork between a pair of terminal leaves. Calyx of 6 short-lived sepals; 6 to 9 rounded, flat petals; stamens as many as petals or (usually) twice as many; 1 pistil, with a thick stigma. Stem: 1 to $1-1 / 2 \mathrm{ft}$. high, from a long, running rootstock. Leaves: Of flowerless stems (from separate rootstock), solitary, on a long petiole from, base, nearly $1 \mathrm{ft}$. across, rounded, centrally peltate, umbrella fashion, 5 to 7 lobed, the lobes 2-cleft, dark above, light green below. Leaves of flowering stem 1 to 3, usually a pair, similar to others, but smaller. Fruit: A fleshy, yellowish, egg-shaped, many-seeded fruit about 2 in. long.

Preferred Habitat-Rich, moist woods.

Flowering Season-May.

Distribution-Quebec to the Gulf of Mexico, westward to Minnesota and Texas.

In giving this plant its abridged scientific name, Linnaeus seemed to see in its leaves a resemblance to a duck's foot (Anapodophyllum); but equally imaginative American children call them green umbrellas, and declare they unfurl only during April showers. In July, a sweetly mawkish many-seeded fruit, resembling a yellow egg-tomato, delights the uncritical palates of the little people, who should be warned, however, against putting any other part of this poisonous, drastic plant in 
their mouths. Physicians best know its uses. Dr. Asa Gray's statement about the harmless fruit "eaten by pigs and boys" aroused William Hamilton Gibson, who had happy memories of his own youthful gorges on anything edible that grew. "Think of it, boys!" he wrote; "and think of what else he says of it: 'Ovary ovoid, stigma sessile, undulate, seeds covering the lateral placenta each enclosed in an aril.' Now it may be safe for pigs and billygoats to tackle such a compound as that, but we boys all like to know what we are eating, and I cannot but feel that the public health officials of every township should require this formula of Doctor Gray's to be printed on every one of these big loaded pills, if that is what they are really made of."

Barberry; Pepperidge-bush

Berberis vulgaris

Flowers-Yellow, small, odor disagreeable, 6-parted, borne in drooping, manyflowered racemes from the leaf axils along arching twigs. Stem: A much-branched, smooth, gray shrub, 5 to $8 \mathrm{ft}$. tall, armed with sharp spines. Leaves: From the 3pronged spines (thorns); oval or obovate, bristly edged. Fruit: Oblong, scarlet, acid berries.

Preferred Habitat—Thickets, roadsides, dry or gravelly soil.

Flowering Season-May-June.

Distribution-Naturalized in New England and Middle states; less common in Canada and the West. Europe and Asia.

When the twigs of barberry bushes arch with the weight of clusters of beautiful bright berries in September, every one must take notice of a shrub so decorative, which receives scant attention from us, however, when its insignificant little flowers are out.

In the barberry bushes, as in the gorse, when grown in dry, gravelly situations, we see many leaves and twigs modified into thorns to diminish the loss of water through evaporation by exposing too much leaf surface to the sun and air. That such spines protect the plants which bear them from the ravages of grazing cattle is, of course, an additional motive for their presence. Under cultivation, in wellwatered garden soil-and how many charming varieties of barberries are cultivated-the thorny shrub loses much of its armor, putting forth many more leaves, in rosettes, along more numerous twigs, instead. Even the prickly pear cactus might become mild as a lamb were it to forswear sandy deserts and live in marshes instead. Country people sometimes rob the birds of the acid berries to make preserves. The wood furnishes a yellow dye. 


\section{POPPY FAMILY (Papaveraceae)}

Bloodroot; Indian Paint; Red Puccoon

\section{Sanguinaria canadensis}

Flowers-Pure white, rarely pinkish, golden centred, 1 to $1-1 / 2$ in. across, solitary, at end of a smooth, naked scape 6 to $14 \mathrm{in}$. tall. Calyx of 2 short-lived sepals; corolla of 8 to 12 oblong petals, early falling; stamens numerous; 1 short pistil composed of 2 carpels. Leaves: Rounded, deeply and palmately lobed, the 5 to 9 lobes often cleft. Rootstock: Thick, several inches long, with fibrous roots, and filled with orange-red juice.

Preferred Habitat—Rich woods and borders; low hillsides.

Flowering Season-April-May.

Distribution-Nova Scotia to Florida, westward to Nebraska.

Snugly protected in a papery sheath enfolding a silvery-green leaf-cloak, the solitary erect bud slowly rises from its embrace, sheds its sepals, expands into an immaculate golden-centred blossom that, poppy-like, offers but a glimpse of its fleeting loveliness ere it drops its snow-white petals and is gone. But were the flowers less ephemeral, were we always certain of hitting upon the very time its colonies are starring the woodland, would it have so great a charm? Here to-day, if there comes a sudden burst of warm sunshine; gone to-morrow, if the spring winds, rushing through the nearly leafless woods, are too rude to the fragile 
petals - no blossom has a more evanescent beauty, none is more lovely. After its charms have been displayed, up rises the circular leaf-cloak on its smooth reddish petiole, unrolls, and at length overtops the narrow, oblong seed-vessel. Wound the plant in any part, and there flows an orange-red juice, which old-fashioned mothers used to drop on lumps of sugar and administer when their children had coughs and colds. As this fluid stains whatever it touches-hence its value to the Indians as a war-paint-one should be careful in picking the flower. It has no value for cutting, of course; but in some rich, shady corner of the garden, a clump of the plants will thrive and bring a suggestive picture of the spring woods to our very doors. It will be noticed that plants having thick rootstock, corms, and bulbs, which store up food during the winter, like the irises, Solomon's seals, bloodroot, adder's tongue, and crocuses, are prepared to rush into blossom far earlier in spring than fibrous-rooted species that must accumulate nourishment after the season has opened.

Greater Celandine; Swallow-wort

Chelidonium majus

Flowers-Lustreless yellow, about $1 / 2$ in. across, on slender pedicels, in a small umbel-like cluster. Sepals 2, soon falling; 4 petals, many yellow stamens, pistil prominent. Stem: Weak, 1 to $2 \mathrm{ft}$. high, branching, slightly hairy, containing bright orange acrid juice. Leaves: Thin, 4 to 8 in. long, deeply cleft into 5 (usually) irregular oval lobes, the terminal one largest. Fruit: Smooth, slender, erect pods, 1 to 2 in. long, tipped with the persistent style.

Preferred Habitat-Dry waste land, fields, roadsides, gardens, near dwellings.

Flowering Season-April-September.

Distribution-Naturalized from Europe in eastern United States. Not this weak invader of our roadsides, whose four yellow petals suggest one of the cross-bearing mustard tribe, but the pert little Lesser Celandine, Pilewort, or Figwort Buttercup (Ficaria Ficaria), one of the crowfoot family, whose larger solitary satiny yellow flowers so commonly star European pastures, was Wordsworth's special delight - a tiny, turf-loving plant, about which much poetical association clusters. Having stolen passage across the Atlantic, it is now making itself at home about College Point, Long Island; on Staten Island; near Philadelphia, and maybe elsewhere. Doubtless it will one day overrun our fields, as so many other European immigrants have done. 
The generic Greek name of the greater celandine, meaning a swallow, was given it because it begins to bloom when the first returning swallows are seen skimming over the water and freshly ploughed fields in a perfect ecstasy of flight, and continues in flower among its erect seed capsules until the first cool days of autumn kill the gnats and small winged insects not driven to cover. Then the swallows, dependent on such fare, must go to warmer climes where plenty still fly. Quaint old Gerarde claims that the Swallow-wort was so called because "with this herbe the dams restore eyesight to their young ones when their eye be put out" by swallows. Coles asserts "the swallow cureth her dim eyes with Celandine." 


\section{FUMITORY FAMILY (Fumariaceae)}

Dutchman's Breeches; White Hearts; Soldier's Cap; Ear-drops

\section{Dicentra Cucullaria}

Flowers-White, tipped with yellow, nodding in a 1-sided raceme. Two scale-like sepals; corolla of 4 petals, in 2 pairs, somewhat cohering into a heart-shaped, flattened, irregular flower, the outer pair of petals extended into 2 widely spread spurs, the small inner petals united above; 6 stamens in 2 sets; style slender, with a 2-lobed stigma. Scape: 5 to $10 \mathrm{in}$. high, smooth, from a bulbous root. Leaves: Finely cut, thrice compound, pale beneath, on slender petioles, all from base.

Preferred Habitat-Rich, rocky woods.

Flowering Season-April-May.

Distribution-Nova Scotia to the Carolinas, west to Nebraska.

Rich leaf mould, accumulated between crevices of rock, makes the ideal home of this delicate yet striking flower, coarse-named, but refined in all its parts. Consistent with the dainty, heart-shaped blossoms that hang trembling along the slender stem like pendants from a lady's ear, are the finely dissected, lace-like leaves, the whole plant repudiating by its femininity its most popular name. It was Thoreau who observed that only those plants which require but little light, and can stand the drip of trees, prefer to dwell in the woods-plants which have commonly more beauty in their leaves than in their pale and almost colorless blos- 
soms. Certainly few woodland dwellers have more delicately beautiful foliage than the fumitory tribe.

\section{Squirrel Corn}

\section{Dicentra canadensis}

Flowers-Irregular, greenish white tinged with rose, slightly fragrant, heartshaped, with 2 short rounded spurs, more than $1 / 2 \mathrm{in}$. long, nodding on a slender Calyx of 2 scale-like sepals; corolla heart-shaped at base, consisting of 4 petals in 2 united pairs, a prominent crest on tips of inner ones; 6 stamens in 2 sets; style with 2-lobed stigma. Scape; Smooth, 6 to 12 in. high, the rootstock bearing many small, round, yellow tubers like kernels of corn. Leaves: All from root, delicate, compounded of 3 very finely dissected divisions.

Preferred Habitat-Rich, moist woods.

Flowering Season-May-June.

Distribution-Nova Scotia to Virginia, and westward to the Mississippi.

Any one familiar with the Bleeding-heart (Dicentra eximia) of old-fashioned gardens, found growing wild in the Alleghanies, and with the exquisite White Mountain Fringe (Adlumia fungosa) often brought from the woods to be planted over shady trellises, or with the Dutchman's breeches, need not be told that the little squirrel corn is next of kin or far removed from the Pink Corydalis. It is not until we dig up the plant and look at its roots that we see why it received its name. A delicious perfume like hyacinths, only fainter and subtler, rises from the dainty blossoms. 


\section{MUSTARD FAMILY (Cruciferae)}

Shepherd's Purse; Mother's Heart

Capsella Bursa-pastoris

Flowers-Small, white, in a long, loose raceme, followed by triangular and notched (somewhat heart-shaped) pods, the valves boat-shaped and keeled. Sepals and petals 4; stamens $6 ; 1$ pistil. Stem: 6 to 18 in. high, from a deep root. Leaves: Forming a rosette at base, 2 to $5 \mathrm{in}$. long, more or less cut (pinnatifid), a few pointed, arrow-shaped leaves also scattered along stem and partly clasping it.

Preferred Habitat—Fields, roadsides, waste places.

Flowering Season-Almost throughout the year.

Distribution-Over nearly all parts of the earth.

From Europe this little low plant found its way, to become the commonest of our weeds, so completing its march around the globe. At a glance one knows it to be related to the alyssum and candytuft of our gardens, albeit a poor relation in spite of its vaunted purses-the tiny, heart-shaped seed-pods that so rapidly succeed the flowers. What is the secret of its successful march over the face of the earth? Like the equally triumphant chickweed, it is easily satisfied with unoccupied waste land, it avoids the fiercest competition for insect trade by prolonging its season of bloom far beyond that of any native flower, for there is not a month in the year when one may not find it even in New England in sheltered places. 
Black Mustard

Brassica nigra

Flowers-Bright yellow, fading pale, $1 / 4$ to $1 / 2$ in. across, 4-parted, in elongated racemes; quickly followed by narrow, upright 4 -sided pods about 1/2 in. long appressed against the stem. Stem: Erect, 2 to $7 \mathrm{ft}$. tall, branching. Leaves: Variously lobed and divided, finely toothed, the terminal lobe larger than the 2 to 4 side ones.

Preferred Habirat-Roadsides, fields, neglected gardens.

Flowering Season-June-November.

Distribution-Common throughout our area; naturalized from Europe and Asia.

"The kingdom of heaven is like unto a grain of mustard seed, which a man took and sowed in his freld: which indeed is less than all seeds; but when it is grown, it is greater than the herbs, and becometh a tree, so that the birds of the air come and lodge in the branches thereof."

Commentators differ as to which is the mustard of the parable-this common Black Mustard, or a rarer shrub-like tree (Salvadora Persica), with an equivalent Arabic name, a pungent odor, and a very small seed. Inasmuch as the mustard which is systematically planted for fodder by Old World farmers grows with the greatest luxuriance in Palestine, and the comparison between the size of its seed and the plant's great height was already proverbial in the East when Jesus used it, evidence strongly favors this wayside weed. Indeed, the late Doctor Royle, who endeavored to prove that it was the shrub that was referred to, finally found that it does not grow in Galilee.

Now, there are two species which furnish the most powerfully pungent condiment known to commerce; but the tiny dark brown seeds of the Black Mustard are sharper than the serpent's tooth, whereas the pale brown seeds of the White Mustard, often mixed with them, are far more mild. The latter (Brassica alba) is a similar, but more hairy, plant, with slightly larger yellow flowers. Its pods are constricted like a necklace between the seeds.

The coarse Hedge Mustard (Sisymbrium officinale), with rigid, spreading branches, and spikes of tiny pale yellow flowers, quickly followed by awl-shaped pods 
that are closely appressed to the stem, abounds in waste places throughout our area. It blooms from May to November, like the next species.

Another common and most troublesome weed from Europe is the Field or Corn Mustard, Charlock or Field Kale (Brassica arvensis) found in grain fields, gardens, rich waste lands, and rubbish heaps. The alternate leaves, which stand boldly out from the stem, are oval, coarsely saw-toothed, or the lower ones more irregular, and lobed at their bases, all rough to the touch, and conspicuously veined. 


\section{PITCHER-PLANT FAMILY (Sarracenaceae)}

Pitcher-plant; Side-saddle Flower; Huntsman’s Cup; Indian Dipper

\section{Sarracenea purpurea}

Flower-Deep reddish purple, sometimes partly greenish, pink, or red, 2 in. or more across, globose; solitary, nodding from scape 1 to $2 \mathrm{ft}$. tall. Calyx of 5 sepaIs, with 3 or 4 bracts at base; 5 overlapping petals, enclosing a yellowish, umbrella-shaped dilation of the style, with 5 rays terminating in 5-hooked stigmas; stamens indefinite. Leaves: Hollow, pitcher-shaped through the folding together of their margins, leaving a broad wing; much inflated, hooded, yellowish green with dark maroon or purple lines and veinings, 4 to $12 \mathrm{in}$. long, curved, in a tuft from the root.

Preferred Habitat-Peat-bogs; spongy, mossy swamps.

Flowering Season-May-June.

Distribution-Labrador to the Rocky Mountains, south to Florida, Kentucky, and Minnesota.

"What's this I hear

About the new carnivora?

Can little plants

Eat bugs and ants 
And gnats and flies?

A sort of retrograding:

Surely the fare

Of flowers is air

Or sunshine sweet;

They shouldn't eat

Or do aught so degrading!”

There must always be something shocking in the sacrifice of the higher life to the lower, of the sensate to what we are pleased to call the insensate, although no one who has studied the marvellously intelligent motives that impel a plant's activities can any longer consider the vegetable creation as lacking sensibility. Science is at length giving us a glimmering of the meaning of the word universe, teaching, as it does, that all creatures in sharing the One Life share in many of its powers, and differ from one another only in degree of possession, not in kind. The transition from one so-called kingdom into another presumably higher one is a purely arbitrary line marked by man, and often impossible to define. The animalcule and the insectivorous plant know no boundaries between the animal and the vegetable. And who shall say that the sundew or the bladderwort is not a higher organism than the amoeba? Animated plants and vegetating animals parallel each other. Several hundred carnivorous plants in all parts of the world have now been named by scientists.

It is well worth a journey to some spongy, sphagnum bog to gather clumps of pitcher-plants which will furnish an interesting study to an entire household throughout the summer while they pursue their nefarious business in a shallow bowl on the veranda. A modification of the petiole forms a deep, hollow pitcher having for its spout a modification of the blade of the leaf. Usually the pitchers are half filled with water and tiny drowned victims when we gather them. Some of this fluid must be rain, but the open pitcher secretes much juice, too. Certain relatives, whose pitchers have hooded lids that keep out rain, are nevertheless filled with fluid. On the Pacific Coast the golden jars of Darlingtonia californica, with their overarching hoods, are often so large and watery as to drown small birds and field mice. Note in passing that these otherwise dark prisons have translucent spots at the top, whereas our pitcher-plant is lighted through its open transom.

A sweet secretion within the pitcher's rim, which some say is intoxicating, others that it is an anesthetic, invites insects to a fatal feast. It is a simple enough matter for them to walk into the pitcher over the band of stiff hairs pointing downward like the withes of a lobster pot, that form an inner covering, or to slip into the 
well if they attempt crawling over its polished upper surface. To fly upward in a perpendicular line, once their wings are wet, is additionally hopeless, because of the hairs that guard the mouth of the trap; and so, after vain attempts to fly or crawl out of the prison, they usually sink exhausted into a watery grave.

When certain plants live in soil that is so poor in nitrogen compounds that proteid formation is interfered with, they have come to depend more or less on a carnivorous diet. The sundew actually digests its prey with the help of a gastric juice similar to what is found in the stomach of animals; but the bladderwort and pitcher-plants can only absorb in the form of soup the products of their victims' decay. Flies and gnats drowned in these pitchers quickly yield their poor little bodies; but owing to the beetle's hard shell covering, many a rare specimen may be rescued intact to add to a collection.

A similar ogre plant is the yellow-flowered Trumpet-leaf (S. flava) found in bogs in the Southern states. 


\section{SUNDEW FAMILY (Droseraceae)}

Round-leaved Sundew; Dew-plant

Drosera rotundifolia

Flowers-Small, white, growing in a 1-sided, curved raceme of buds chiefly. Calyx usually 5-parted; usually 5 petals, and as many stamens as petals; usually 3 styles, but 2-cleft, thus appearing to be twice as many. Scape: 4 to $10 \mathrm{in}$. high. Leaves: Growing in an open rosette on the ground; round or broader, clothed with reddish bristly hairs tipped with purple glands, and narrowed into long, flat, hairy petioles; young leaves curled like fern fronds.

Preferred Habitat-Bogs, sandy and sunny marshes.

Flowering Season-July-August. Distribution-Labrador to the Gulf of Mexico and westward. From Alaska to California. Europe and Asia.

Here is a bloodthirsty little miscreant that lives by reversing the natural order of higher forms of life preying upon lower ones, an anomaly in that the vegetable actually eats the animal. The dogbane, as we shall see, simply catches the flies that dare trespass upon the butterflies' preserves, for excellent reasons of its own; the Silenes and phloxes, among others, spread their calices with a sticky gum that acts as limed twigs do to birds, in order to guard the nectar secreted for flying benefactors from pilfering ants; the honey bee being an imported, not a native, insect, and therefore not perfectly adapted to the milkweed, occasionally gets entrapped by it; the big bumblebee is sometimes fatally imprisoned in the moccasin flower's 
gorgeous tomb-the punishment of insects that do not benefit the flowers is infinite in its variety. But the local Venus's flytrap (Dionaea muscipula), gathered only from the low savannas in North Carolina to entertain the owners of hothouses as it promptly closes the crushing trap at the end of its sensitive leaves over a hapless fly, and the common sundew that tinges the peat-bogs of three continents with its little reddish leaves, belong to a distinct class of carnivorous plants which actually masticate their animal food, depending upon it for nourishment as men do upon cattle slaughtered in an abattoir. Darwin's huminous account of these two species alone, which occupies more than three hundred absorbingly interesting pages of his "Insectivorous Plants," should be read by every one interested in these freaks of nature.

When we go to some sunny cranberry bog to look for these sundews, nothing could be more innocent looking than the tiny plant, its nodding raceme of buds, usually with only a solitary little blossom (that opens only in the sunshine) at the top of the curve, its leaves glistening with what looks like dew, though the midsummer sun may be high in the heavens. A little fly or gnat, attracted by the bright jewels, alights on a leaf only to find that the clear drops, more sticky than honey, instantly glue his feet, that the pretty reddish hairs about him act like tentacles, reaching inward, to imprison him within their slowly closing embrace. Here is one of the horrors of the Inquisition operating in this land of liberty before our very eyes! Excited by the struggles of the victim, the sensitive hairs close only the faster, working on the same principle that a vine's tendrils do when they come in contact with a trellis. More of the sticky fluid pours upon the hapless fly, plastering over his legs and wings and the pores on his body through which he draws his breath. Slowly, surely, the leaf rolls inward, making a temporary stomach; the cruel hairs bind, the glue suffocates and holds him fast. Death alone releases him. And now the leaf's orgy begins: moistening the fly with a fresh peptic fluid, which helps in the assimilation, the plant proceeds to digest its food. Curiously enough, chemical analysis proves that this sundew secrets a complex fluid corresponding almost exactly to the gastric juice in the stomach of animals.

Darwin, who fed these leaves with various articles, found that they could dissolve matter out of pollen, seeds, grass, etc.; yet without a human caterer, how could a leaf turn vegetarian? When a bit of any undesirable substance, such as chalk or wood, was placed on the hairs and excited them, they might embrace it temporarily; but as soon as the mistake was discovered, it would be dropped! He also poisoned the plants by administering acids, and gave them fatal attacks of indigestion by overfeeding them with bits of raw beef? 


\section{SAXIFRAGE FAMILY (Saxifragaceae)}

\section{Early Saxifrage}

Saxifraga virginiensis

Flowers-White, small, numerous, perfect, spreading into a loose panicle. Calyx 5-lobed; 5 petals; 10 stamens; 1 pistil with 2 styles. Scape: 4 to 12 in. high, naked, sticky-hairy. Leaves: Clustered at the base, rather thick, obovate, toothed, and narrowed into spatulate-margined petioles. Fruit: Widely spread, purplish brown pods.

Preferred Habitat-Rocky woodlands, hillsides.

Flowering Season-March-May.

Distribution-New Brunswick to Georgia, and westward a thousand miles or more.

Rooted in clefts of rock that, therefore, appears to be broken by this vigorous plant, the saxifrage shows rosettes of fresh green leaves in earliest spring, and soon whitens with its blossoms the most forbidding niches. (Saxum $=$ a rock; frango $=$ I break.) At first a small ball of green buds nestles in the leafy tuffet, then pushes upward on a bare scape, opening its tiny, white, five-pointed star flowers as it ascends, until, having reached the allotted height, it scatters them in spreading clusters that last a fortnight. 
Foam-flower; False Miterwort; Cool wort; Nancy-over-the-Ground

\section{Tiarella cordifolia}

Flowers - White, small, feathery, borne in a close raceme at the top of a scape 6 to 12 in. high. Calyx white, 5-lobed; 5 clawed petals; 10 stamens, long-exserted; 1 pistil with 2 styles. Leaves: Long-petioled from the rootstock or rumners, rounded or broadly heart-shaped, 3 to 7-lobed, toothed, often downy along veins beneath.

Preferred Habitat-Rich, moist woods, especially along mountains.

Flowering Season-April-May.

Distribution-Nova Scotia to Georgia, and westward scarcely to the Mississippi.

Fuzzy, bright white foam-flowers are most conspicuous in the forest when seen against their unevenly colored leaves that carpet the ground. A relative, the true Miterwort or Bishop's Cap (Mittella diphylla), with similar foliage, except that two opposite leaves may be found almost seated near the middle of its hairy stem, has its flowers rather distantly scattered on the raceme, and their fine petals deeply cut like fringe. Both species may be found in bloom at the same time, offering an opportunity for comparison to the confused novice. Now, tiarella, meaning a little tiara, and mitella, a little miter, refer, of course, to the odd forms of their seedcases; but all of us are not gifted with the imaginative eyes of Linnaeus, who named the plants. Xenophon's assertion that the royal tiara or turban of the Persians was encircled with a crown helps us no more to see what Linnaeus saw in the one case than the fact that the papal miter is encircled by three crowns helps in the other. And as for the lofty, two-peaked cap worn by Bishops in the Roman Church, a dozen plants, with equal propriety, might be said to wear it.

\section{Grass of Parnassus}

\section{Parnassia caroliniana}

Flowers-Creamy white, delicately veined with greenish, solitary, $1 \mathrm{in}$. broad or over, at the end of a scape $8 \mathrm{in}$. to $2 \mathrm{fr}$. high, 1 ovate leaf clasping it. Calyx deeply 5-lobed; corolla of 5 spreading, parallel veined petals; 5 fertile stamens alternating with them, and 3 stout imperfect stamens clustered at base of each petal; 1 very short pistil with 4 stigmas. Leaves: From the root, on long petioles, broadly oval or rounded, heart-shaped at base, rather thick. 
Preferred Habitat-Wet ground, low meadows, swamps.

Flowering Season-July-September.

Distribution-New Brunswick to Virginia, west to Iowa.

What's in a name? Certainly our common grass of Parnassus, which is no grass at all, never starred the meadows round about the home of the Muses, nor sought the steaming savannas of the Carolinas. The European counterpart (P. palustris), fabled to have sprung up on Mount Parnassus, is at home here only in the Canadian border states and northward. 


\section{WITCH-HAZEL FAMILY (Hamamelidaceae)}

\section{Witch-hazel}

\section{Hamamelis virginiana}

Flowers-Yellow, fringy, clustered in the axils of branches. Calyx 4-parted; 4 very narrow curving petals about $3 / 4$ in. long; 4 short stamens, also 4 that are scalelike; 2 styles. Stem: A tall, crooked shrub. Leaves: Broadly oval, thick, wavytoothed, mostly fallen at flowering time. Fruit: Woody capsules maturing the next season and remaining with flowers of the succeeding year (Hama = together with; mela $=$ fruit $)$.

The literature of Europe is filled with allusions to the witch-hazel, which, however, is quite distinct from our shrub. Swift wrote:
"They tell us something strange and odd
About a certain magic rod
That, bending down its top divines
Where'er the soil has hidden mines;
Where there are none, it stands erect
Scorning to show the least respect."

A good story is told on Linnaeus in Baring-Gould's "Curious Myths of the Middle Ages": "When the great botanist was on one of his voyages, hearing his secretary highly extol the virtues of his divining-wand, he was willing to convince him of its insufficiency, and for that purpose concealed a purse of one hundred 
ducats under a ranunculus, which grew by itself in a meadow, and bid the secretary find it if he could. The wand discovered nothing, and Linnaeus's mark was soon trampled down by the company present, so that when he went to finish the experiment by fetching the gold himself, he was utterly at a loss where to find it. The man with the wand assisted him, and informed him that it could not lie in the way they were going, but quite the contrary; so they pursued the direction of the wand, and actually dug out the gold. Linnaeus said that another such experiment would be sufficient to make a proselyte of him."

Many a well has been dug even in this land of liberty where our witch-hazel indicated; but here its kindly magic is directed chiefly through the soothing extract distilled from its juices. Its yellow, thread-like blossoms are the latest to appear in the autumn woods. 
ROSE FAMILY (Rosaceae)

Hardhack; Steeple Bush

Spiraea tomentosa

Flowers - Pink or magenta, rarely white, very small, in dense, pyramidal clusters. Calyx of 5 sepals; corolla of 5 rounded petals; stamens, 20 to 60; usually 5 pistils, downy. Stem: 2 to $3 \mathrm{ft}$. high, erect, shrubby, simple, downy. Leaves: Dark green above, covered with whitish woolly hairs beneath; oval, saw-edged, 1 to 2 in. long.

Preferred Habitat - Low, moist ground, roadside ditches, swamps.

Flowering Season-July-September.

Distribution-Nova Scotia westward, and southward to Georgia and Kansas.

An instant's comparison shows the steeple bush to be closely related to the fleecy, white meadow-sweet, often found growing near. The pink spires, which bloom from the top downward, have pale brown tips where the withered flowers are, toward the end of summer.

Why is the underside of the leaves so woolly? Not as a protection against wingless insects crawling upward, that is certain; for such could only benefit these tiny clustered flowers. Not against the sun's rays, for it is only the under surface that is coated. When the upper leaf surface is hairy, we know that the plant is protected in this way from perspiring too freely. Doubtless these leaves of the steeple bush, 
like those of other plants that choose a similar habitat, have woolly hairs beneath as an absorbent to protect their pores from clogging with the vapors that must rise from the damp ground where the plant grows. If these pores were filled with moisture from without, how could they possibly throw off the waste of the plant? All plants are largely dependent upon free perspiration for health, but especially those whose roots, struck in wet ground, are constantly sending up moisture through the stem and leaves.

Meadow-sweet; Quaker Lady; Queen-of-the-Meadow

Spiraea salicifolia

Flowers-Small, white, or flesh pink, clustered in dense, pyramidal terminal panicles. Calyx 5 cleft; corolla of 5 rounded petals; stamens numerous; pistils 5 to 8 . Stem: 2 to $4 \mathrm{ft}$. high, simple or bushy, smooth, usually reddish. Leaves: Alternate, oval, or oblong, saw-edged.

Preferred Habitat-Low meadows, swamps, fence-rows, ditches.

Flowering Season-June-August.

Distribution-Newfoundland to Georgia, west to Rocky Mountains. Europe and Asia.

Fleecy white plumes of meadow-sweet, the "spires of closely clustered bloom" sung by Dora Read Goodale, are surely not frequently found near dusty "waysides scorched with barren heat," even in her Berkshires; their preference is for moister soil, often in the same habitat with a first cousin, the pink steeple-bush. But plants, like humans, are capricious creatures. If the meadow-sweet always elected to grow in damp ground whose rising mists would clog the pores of its leaves, doubtless they would be protected with a woolly absorbent, as its cousins are.

Inasmuch as perfume serves as an attraction to the more highly specialized, aesthetic insects, not required by the spiraeas, our meadow-sweet has none, in spite of its misleading name. Small bees, flies, and beetles, among other visitors, come in great numbers, seeking the accessible pollen, and, in this case, nectar also, secreted in a conspicuous orange-colored disk.

Common Hawthorn; White Thorn; Scarlet-fruited Thorn; Red Haw; Mayflower 
Flowers-White, rarely pinkish, usually less than $1 \mathrm{in}$. across, numerous, in terminal corymbs. Calyx 5-lobed; 5 spreading petals inserted in its throat; numerous stamens; styles 3 to 5. Stem: A shrub or small tree, rarely attaining $30 \mathrm{ft}$. in height (Kratos = strength, in reference to hardness and toughness of the wood); branches spreading, and beset with stout spines (thorns) nearly 2 in. long. Leaves: Alternate, petioled, 2 to $3 \mathrm{in}$. long, ovate, very sharply cut or lobed, the teeth glandular-tipped. Fruit: Coral red, round or oval; not edible.

Preferred Habitat-Thickets, fence-rows, woodland borders.

Flowering Season-May.

Distribution-Newfoundland and Manitoba southward to the Gulf of Mexico.

"The fair maid who, the first of May,

Goes to the fields at break of day

And washes in dew from the hawthorn tree

Will ever after handsome be."

Here is a popular recipe omitted from that volume of heart-to-heart talks entitled "How to Be Pretty Though Plain!"

The sombre-thoughted Scotchman, looking for trouble, tersely observes:

"Mony haws,

Mony snaws."

But in delicious, blossoming May, when the joy of living fairly intoxicates one, and every bird's throat is swelling with happy music, who but a Calvinist would croak dismal prophecies? In Ireland, old crones tell marvellous tales about the hawthorns, and the banshees which have a predilection for them.

Five-finger; Common Cinquefoil

Potentilla canadensis

Flowers-Yellow, $1 / 4$ to $1 / 2$ in. across, growing singly on long peduncles from the leaf axils. Five petals longer than the 5 acute calyx lobes with 5 linear bracts between them; about 20 stamens; pistils numerous, forming a head. Stem: Spreading over ground by slender runners or ascending. Leaves: 5 -fingered, the 
digitate, saw-edged leaflets (rarely 3 or 4) spreading from a common point, petioled; some in a tuft at base.

Preferred Habitat—Dry fields, roadsides, hills, banks.

Flowering Season-April-August.

Distribution-Quebec to Georgia, and westward beyond the Mississippi.

Every one crossing dry fields in the eastern United States and Canada at least must have trod on a carpet of cinquefoil (cinque $=$ five, feuilles $=$ leaves), and have noticed the bright little blossoms among the pretty foliage, possibly mistaking the plant for its cousin, the trefoliate barren strawberry. Both have flowers like miniature wild yellow roses. During the Middle Ages, when misdirected zeal credited almost any plant with healing virtues for every ill that flesh is heir to, the cinquefoils were considered most potent remedies, hence their generic name.

High Bush Blackberry; Bramble

Rubus villosus

Flowers-White, $1 \mathrm{in}$. or less across, in terminal raceme-like clusters. Calyx deeply 5-parted, persistent; 5 large petals; stamens and carpels numerous, the latter inserted on a pulpy receptacle. Stem: 3 to $10 \mathrm{ft}$. high, woody, furrowed, curved, armed with stout, recurved prickles. Leaves: Compounded of 3 to 5 ovate, saw-edged leaflets, the end one stalked, all hairy beneath. Fruit: Firmly attached to the receptacle; nearly black, oblong juicy berries $1 \mathrm{in}$. long or less, hanging in clusters. Ripe, July-August.

Preferred Habitat-Dry soil, thickets, fence-rows, old fields, waysides. Low altitudes.

Flowering Season-May-June.

Distribution-New England to Florida, and far westward.

"There was a man of our town, And he was wondrous wise, He jumped into a bramble bush"-

If we must have poetical associations for every flower, Mother Goose furnishes several. 
But for the practical mind this plant's chief interest lies in the fact that from its wild varieties the famous Lawton and Kittatinny blackberries have been derived. The late Peter Henderson used to tell how the former came to be introduced. A certain Mr. Secor found an unusually fine blackberry growing wild in a hedge at New Rochelle, New York, and removed it to his garden, where it increased apace. But not even for a gift could he induce a neighbor to relieve him of the superfluous bushes, so little esteemed were blackberries in his day. However, a shrewd lawyer named Lawton at length took hold of it, exhibited the fruit, advertised it cleverly, and succeeded in pocketing a snug little fortune from the sale of the prolific plants. Another fine variety of the common wild blackberry, which was discovered by a clergyman at the edge of the woods on the Kittatinny Mountains in New Jersey, has produced fruit under skilled cultivation that still remains the best of its class. When clusters of blossoms and fruit in various stages of green, red, and black hang on the same bush, few ornaments in Nature's garden are more decorative.

Purple-flowering or Virginia Raspberry

Rubus odoratus

Flowers-Royal purple or bluish pink, showy, fragrant, 1 to 2 in. broad, loosely clustered at top of stem. Calyx sticky-hairy, deeply 5-parted, with long, pointed tips; corolla of 5 rounded petals; stamens and pistils very numerous. Stem: 3 to 5 ft. high, erect, branched, shrubby, bristly, not prickly. Leaves: Alternate, petioled, 3 to 5 lobed, middle lobe largest, and all pointed; saw-edged lower leaves immense. Fruit: A depressed red berry, scarcely edible.

Preferred Habitat-Rocky woods, dells, shady roadsides.

Flowering Season-June-August.

Distribution-Northern Canada south to Georgia, westward to Michigan and Tennessee.

To be an unappreciated, unloved relative of the exquisite wild rose, with which this flower is so often likened, must be a similar misfortune to being the untalented son of a great man, or the unhappy author of a successful first book never equalled in later attempts. But where the bright blossoms of the Virginia raspberry burst forth above the roadside tangle and shady woodland dells, even those 
who despise magenta see beauty in them where abundant green tones all discordant notes into harmony. Purple, as we of to-day understand the color, the flower is not; but rather the purple of ancient Orientals. On cool, cloudy days the petals are a deep rose that fades into bluish pink when the sun is hot.

\section{Wild Roses}

Rosa

Just as many members of the lily tribe show a preference for the rule of three in the arrangements of their floral parts, so the wild roses cling to the quinary method of some primitive ancestor, a favorite one also with the buttercup and many of its kin, the geraniums, mallows, and various others. Most of our fruit trees and bushes are near relatives of the rose. Five petals and five sepals, then, we always find on roses in a state of nature; and although the progressive gardener of to-day has nowhere shown his skill more than in the development of a multitude of petals from stamens in the magnificent roses of fashionable society, the most highly cultivated darling of the greenhouses quickly reverts to the original wild type, setting his work of years at naught, if once it regain its natural liberties through neglect.

To protect its foliage from being eaten by hungry cattle, the rose goes armed into the battle of life with curved, sharp prickles, not true thorns or modified branches, but merely surface appliances which peel off with the bark. To destroy crawling pilferers of pollen, several species coat their calices, at least, with fine hairs or sticky gum; and to insure wide distribution of offspring, the seeds are packed in the attractive, bright red calyx tube or hip, a favorite food of many birds, which drop them miles away.

In literature, ancient and modern, sacred and profane, no flower figures so conspicuously as the rose. To the Romans it was most significant when placed over the door of a public or private banquet hall. Each who passed beneath it bound himself thereby not to disclose anything said or done within; hence the expression sub rosa, common to this day.

The Smoother, Early, or Meadow Rose (R. blanda), found blooming in June and July in moist, rocky places from Newfoundland to New Jersey and a thousand miles westward, has slightly fragrant flowers, at first pink, later pure white. Their styles are separate, not cohering in a column nor projecting as in the climbing rose. This is a leafy, low bush mostly less than three feet high; it is either entirely unarmed, or else provided with only a few weak prickles; the stipules are rather 
broad, and the leaf is compounded of from five to seven oval, blunt, and pale green leaflets, often hoary below.

In swamps and low, wet ground from Quebec to Florida and westward to the Mississippi, the Swamp Rose (R. carolina) blooms late in May and on to midsummer. The bush may grow taller than a man, or perhaps only a foot high. It is armed with stout, hooked, rather distant prickles, and few or no bristles. The leaflets, from five to nine, but usually seven, to a leaf, are smooth, pale, or perhaps hairy beneath to protect the pores from filling with moisture arising from the wet ground. Long, sharp calyx lobes, which drop off before the cup swells in fruit into a round, glandular, hairy red hip, are conspicuous among the clustered pink flowers and buds.

How fragrant are the pages of Chaucer, Spenser, and Shakespeare with the Eglantine! This delicious plant, known here as Sweetbrier (R. rubiginosa), emits its very aromatic odor from russet glands on the under, downy side of the small leaflets, always a certain means of identification. From eastern Canada to Virginia and Tennessee the plant has happily escaped from man's gardens back to Nature's.

In spite of its American Indian name, the lovely white Cherokee Rose (R. Sinica), that runs wild in the South, climbing, rambling, and rioting with a truly Oriental abandon and luxuriance, did indeed come from China. Would that our northern thickets and roadsides might be decked with its pure flowers and almost equally beautiful dark, glossy, evergreen leaves! 


\section{PULSE FAMILY (Leguminosae)}

Wild or American Senna

Cassia marylandica

Flowers-Yellow, about 3/4 in. broad, numerous, in short axillary clusters on the upper part of plant. Calyx of 5 oblong lobes; 5 petals, 3 forming an upper lip, 2 a lower one; 10 stamens of 3 different kinds; 1 pistil. Stem: 3 to $8 \mathrm{ft}$. high, little branched. Leaves: Alternately pinnately compounded of 6 to 10 pairs of oblong leaflets. Fruit: A narrow, flat curving pod, 3 to 4 in. long.

Preferred Habitat-Alluvial or moist, rich soil, swamps, roadsides.

Flowering Season-July-August.

Distribution-New England, westward to Nebraska, south to the Gulf States.

Whoever has seen certain Long Island roadsides bordered with wild senna, the brilliant flower clusters contrasted with the deep green of the beautiful foliage, knows that no effect produced by art along the drives of public park or private garden can match these country lanes in simple charm.

While leaves of certain African and East Indian species of senna are most valued for their medicinal properties, those of this plant are largely collected in the Middle and Southern states as a substitute. Caterpillars of several sulphur butterflies, which live exclusively on cassia foliage, appear to feel no evil effects from overdoses. 
Wild Indigo; Yellow or Indigo Broom; Horsefly Weed

\section{Baptisia tinctoria}

Flowers - Bright yellow, papilionaceous, about $1 / 2 \mathrm{in.}$ long, on short pedicels, in numerous but few flowered terminal racemes. Calyx light green, 4 or 5 -toothed; corolla of 5 oblong petals, the standard erect, the keel enclosing 10 incurved stamens and 1 pistil. Stem: Smooth, branched, 2 to $4 \mathrm{ft}$. high. Leaves: Compounded of 3 ovate leaflets. Fruit: A many-seeded round or egg-shaped pod tipped with the awl-shaped style.

Preferred Habitat-Dry, sandy soil.

Flowering Season-June-September.

Distribution-Maine and Minnesota to the Gulf states.

Dark grayish green, clover-like leaves, and small, bright yellow flowers growing in loose clusters at the ends of the branches of a bushy little plant, are so commonly met with they need little description. A relative, the true indigo-bearer, a native of Asia, once commonly grown in the Southern states when slavery made competition with Oriental labor possible, has locally escaped and become naturalized. But the false species, although, as Doctor Gray says, it yields "a poor sort of indigo," yields a most valuable medicine employed by the homoeopathists in malarial fevers. The plant turns black in drying. As in the case of other papilionaceous blossoms, bees are the visitors best adapted to fertilize the flowers. When we see the little, sleepy, dusky-winged butterfly (Thanaos brizo) around the plant we may know she is there only to lay eggs, that the larvae and caterpillars may find their favorite food at hand on waking into life.

Wild Lupine; Old Maid's Bonnets; Wild Pea; Sun Dial

\section{Lupinus perennis}

Flowers-Vivid blue, very rarely pink or white, butterfly-shaped; corolla consisting of standard, wings, and keel; about $1 / 2 \mathrm{in}$. long, borne in a long raceme at end of stem; calyx 2-lipped, deeply toothed. Stem: Erect, branching, leafy, 1 to 2 $\mathrm{ft}$. high. Leaves: Palmate, compounded of from 7 to 11 (usually 8) leaflets. Fruit: A broad, flat, very hairy pod, 1-1/2 in. long, and containing 4 or 5 seeds. 
Preferred Habitat—Dry, sandy places, banks, and hillsides.

Flowering Season-May-June.

Distribution-United States east of Mississippi, and eastern Canada.

Farmers once thought that this plant preyed upon the fertility of their soil, as we see in the derivation of its name, from lupus, a wolf; whereas the lupine contents itself with sterile waste land no one should grudge it-steep, gravelly banks, railroad tracks, exposed sunny hills, where even it must often burn out under fierce sunshine did not its root penetrate to surprising depths. It spreads far and wide in thrifty colonies, reflecting the vivid color of June skies, until, as Thoreau says, "the earth is blued with it."

The lupine is another of those interesting plants which go to sleep at night. Some members of the genus erect one half of the leaf and droop the other half until it becomes a vertical instead of the horizontal star it is by day. Frequently the leaflets rotate as much as 90 degrees on their own axes. Some lupines fold their leaflets, not at night only, but during the day also there is more or less movement in the leaves. Sun dial, a popular name for the wild lupine, has reference to this peculiarity. The leaf of our species shuts downward around its stem umbrella fashion, or the leaflets are erected to prevent the chilling which comes to horizontal surfaces by radiation, some scientists think. "That the sleep movements of leaves are in some manner of high importance to the plants which exhibit them," says Darwin, "few will dispute who have observed how complex they sometimes are."

Common Red, Purple, Meadow, or Honeysuckle Clover

\section{Trifolium pratense}

Flowers-Magenta, pink, or rarely whitish, sweet-scented, the tubular corollas set in dense round, oval, or egg-shaped heads about 1 in. long, and seated in a sparingly hairy calyx. Stem: 6 in. to $2 \mathrm{ft}$. high, branching, reclining, or erect, more or less hairy. Leaves: On long petioles, commonly compounded of 3, but sometimes of 4 to 11 oval or oblong leaflets, marked with white crescent, often dark-spotted near centre; stipules egg-shaped, sharply pointed, strongly veined, more than $1 / 2$ in. long.

Preferred Habitat—Fields, meadows, roadsides.

Flowering Season-April-November. 


\section{Distribution-Common throughout Canada and United States.}

Meadows bright with clover-heads among the grasses, daisies, and buttercups in June resound with the murmur of unwearying industry and rapturous enjoyment. Bumblebees by the tens of thousands buzzing above acres of the farmer's clover blossoms should be happy in a knowledge of their benefactions, which doubtless concern them not at all. They have never heard the story of the Australians who imported quantities of clover for fodder, and had glorious fields of it that season, but not a seed to plant next year's crops, simply because the farmers had failed to import the bumblebee. After her immigration the clovers multiplied prodigiously.

No; the bee's happiness rests on her knowledge that only the butterflies' long tongues can honestly share with her the brimming wells of nectar in each tiny floret. Children who have sucked them too appreciate her rapture. If we examine a little flower under the magnifying glass, we shall see why its structure places it in the pea family. Bumblebees so depress the keel either when they sip, or feed on pollen, that their heads and tongues get well dusted with the yellow powder, which they transfer to the stigmas of other flowers; whereas the butterflies are of doubtful value, if not injurious, since their long, slender tongues easily drain the nectar without depressing the keel. Even if a few grains of pollen should cling to their tongues, it would probably be wiped off as they withdrew them through the narrow slit, where the petals nearly meet, at the mouth of the flower. Bombus terrestris delights in nipping holes at the base of the tube, which other pilferers also profit by. Our country is so much richer in butterflies than Europe, it is scarcely surprising that Professor Robertson found thirteen Lepidoptera out of twenty insect visitors to this clover in Illinois, whereas Muller caught only eight butterflies on it out of a list of thirty-nine visitors in Germany. The fritillaries and the sulphurs are always seen about the clover fields among many others, and the "dusky wings" and the caterpillar of several species feed almost exclusively on this plant.

"To live in clover," from the insect's point of view at least, may well mean a life of luxury and affluence. Most peasants in Europe will tell you that a dream about the flower foretells not only a happy marriage, but long life and prosperity. For ages the clover has been counted a mystic plant, and all sorts of good and bad luck were said to attend the finding of variations of its leaves which had more than the common number of leaflets. At evening these leaflets fold downward, the side ones like two hands clasped in prayer, the end one bowed over them. In this fashion the leaves of the white and other clovers also go to sleep, to protect their sensitive surfaces from cold by radiation, it is thought. 
White Sweet Clover; Bokhara or Tree Clover; White Melilot; Honey Lotus

\section{Melilotus alba}

Flowers-Small, white, fragrant, papilionaceous, the standard petal a trifle longer than the wings; borne in slender racemes. Stem: 3 to $10 \mathrm{ft}$. tall, branching. Leaves: Rather distant, petioled, compounded of 3 oblong, saw-edged leaflets; fragrant, especially when dry.

Preferred Habitat - Waste lands, roadsides.

Flowering Season-June-November.

Distribution-United States, Europe, Asia.

Both the White and the Yellow Sweet Clover put their leaves to sleep at night in a remarkable manner: the three leaflets of each leaf twist through an angle of 90 degrees, until one edge of each vertical blade is uppermost. The two side leaflets, Darwin found, always tend to face the north with their upper surface, one facing north-northwest and the other north-northeast, while the terminal leaflet escapes the chilling of its sensitive upper surface through radiation by twisting to a vertical also, but bending to either east or west, until it comes in contact with the vertical upper surface of either of the side leaflets. Thus the upper surface of the terminal and of at least one of the side leaflets is sure to be well protected through the night; one is "left out in the cold."

The dried branches of sweet clover will fill a room with delightful fragrance; but they will not drive away flies, nor protect woollens from the ravages of moths, as old women once taught us to believe.

The ubiquitous White or Dutch Clover (Trifolium repens), whose creeping branches send up solitary round heads of white or pinkish flowers on erect, leafless stems, from May to December, in fields, open waste land, and cultivated places throughout our area, Europe, and Asia, devotes itself to wooing bees, since these are the only insects that effect cross-fertilization regularly, other visitors aiding it only occasionally. Its foliage is the favorite food of very many species of caterpillars and of all grazing cattle the world around. This is still another plant frequently miscalled shamrock. Good luck or bad attends the finding of the 
leaves, when compounded of an even or an odd number of leaflets more than the normal count, according to the saying of many simple-minded folk.

Blue, Tufted, or Cow Vetch or Tare; Cat Peas; Tinegrass

Vicia Cracca

Flowers-Blue, later purple; $1 / 2$ in. long, growing downward in 1-sided spike, 15 to 40 flowered; calyx oblique, small, with unequal teeth; corolla butterfly-shaped, consisting of standard, wings, and keel, all oblong; the first clawed, the second oblique, and adhering to the shorter keel; 10 stamens, 1 detached from other 9. Stem: Slender, weak, climbing or trailing, downy, 2 to $4 \mathrm{ft}$. long. Leaves: Tendril bearing, divided in to 18 to 24 thin, narrow, oblong leaflets. Fruit: A smooth pod $1 \mathrm{in.}$ long or less, 5 to 8 seeded.

Preferred Habitat—Dry soil, fields, waste land.

Flowering Season-June-August.

Distribution-United States from New Jersey, Kentucky, and Iowa northward and northwestward. Europe and Asia.

Dry fields blued with the bright blossoms of the Tufted Vetch, and roadsides and thickets where the angular vine sends forth vivid patches of color, resound with the music of happy bees. Although the parts of the flower fit closely together, they are elastic, and opening with the energetic visitor's weight and movement give ready access to the nectary. On his departure they resume their original position, to protect both nectar and pollen from rain and pilferers whose bodies are not perfectly adapted to further the flower's cross-fertilization. The common bumblebee (Bombus terrestris) plays a mean trick, all too frequently, when he bites a hole at the base of the blossom, not only gaining easy access to the sweets for himself, but opening the way for others less intelligent than he, but quite ready to profit by his mischief, and so defeat nature's plan. Doctor Ogle observed that the same bee always acts in the same manner, one sucking the nectar legitimately, another always biting a hole to obtain it surreptitiously, the natural inference, of course, being that some bees, like small boys, are naturally depraved.

Ground-nut

Apios tuberosa (A. Apios) 
Flowers-Fragrant, chocolate brown and reddish purple, numerous, about 1/2 in. long, clustered in racemes from the leaf axils. Calyx 2-lipped, corolla papilionaceous, the broad standard petal turned backward, the keel sickle-shaped; stamens within it 9 and 1. Stem: From tuberous, edible rootstock; climbing, slender, several feet long, the juice milky. Leaves: Compounded of 5 to 7 ovate leaflets. Fruit: A leathery, slightly curved pod, 2 to $4 \mathrm{in}$. long.

Preferred Habitat-Twining about undergrowth and thickets in moist or wet ground.

Flowering Season-July-September.

Distribution-New Brunswick to Ontario, south to the Gulf states and Kansas.

No one knows better than the omnivorous "barefoot boy" that

"Where the ground-nut trails its vine"

there is hidden something really good to eat under the soft, moist soil where legions of royal fern, usually standing guard above it, must be crushed before he digs up the coveted tubers. He would be the last to confuse it with the Wild Kidney Bean or Bean Vine (Phaseolus polystachyus). The latter has loose racemes of smaller purple flowers and leaflets in threes; nevertheless it is often confounded with the ground-nut vine by older naturalists whose knowledge was "learned of schools."

\section{Wild or Hog Peanut}

Amphicarpa monoica (Falcata comosa)

Flowers-Numerous small, showy ones, borne in drooping clusters from axils of upper leaves; lilac, pale purplish, or rarely white, butterfly-shaped, consisting of standard petal partly enfolding wings and keel. Calyx tubular, 4 or 5 toothed; 10 stamens (9 and 1); 1 pistil. (Also solitary fertile flowers, lacking petals, on threadlike, creeping branches from lower axils or underground.) Stem: Twining wiry brownish-hairy, 1 to $8 \mathrm{ft}$. long. Leaves: Compounded of 3 thin leaflets, eggshaped at base, acutely pointed at tip. Fruit: Hairy pod 1 in. long. Also 1-seeded, pale, rounded, underground peanut.

Preferred Habitat-Moist thickets, shady roadsides. 
Flowering Season-August-September.

Distribution-New Brunswick westward to Nebraska, south to Gulf of Mexico.

Amphicarpa ("seed at both ends"), the Greek name by which this graceful vine is sometimes known, emplasizes its most interesting feature, that, nevertheless, seems to many a foolish duplication of energy on Nature's part. Why should the same plant bear two kinds of blossoms and seeds? Among the foliage of low shrubbery and plants in shady lanes and woodside thickets, we see the delicate, drooping clusters of lilac blossoms hanging where bees can readily discover them and, in pilfering their sweets, transfer their pollen from flower to flower. But in case of failure to intercross these blossoms that are dependent upon insect help to set fertile seed, what then? Must the plant run the risk of extinction? Self-fertilization may be an evil, but failure to produce seed at all is surely the greatest one. To guard against such a calamity, insignificant looking flowers that have no petals to open for the enticing of insects, but which fertilize themselves with their own pollen, produce abundant seed close to the ground or under it. Then what need of the showy blossoms hanging in the thicket above? Close inbreeding in the vegetable world, as in the animal, ultimately produces degenerate offspring; and although the showy lilac blossoms of the wild peanut yield comparatively few cross-fertilized seeds, these are quite sufficient to enable the vine to maintain those desired features which are the inheritance from ancestors that struggled in their day and generation after perfection. No plant dares depend upon its cleistogamous or blind flowers alone for offspring; and in the sixty or more genera containing these curious growths, that usually look like buds arrested in development, every plant that bears them bears also showy flowers dependent upon crosspollination by insect aid.

The boy who:

"Drives home the cows from the pasture

Up through the long shady lane"

knows how reluctantly they leave the feast afforded by the wild peanut. Hogs, rooting about in the moist soil where it grows, unearth the hairy pods that should produce next year's vines; hence the poor excuse for branding a charming plant with a repellent folk-name.

This plant should not be confused with pig-nut (carya porcina), which is a species of hickory. 


\section{WOOD-SORREL FAMILY (Oxalidaceae)}

White or True Wood-sorrel; Alleluia

Oxalis acetosella

Flowers-White or delicate pink, veined with deep pink, about $1 / 2$ in. long. Five sepals; 5 spreading petals rounded at tips; 10 stamens, 5 longer, 5 shorter, all anther-bearing; 1 pistil with 5 stigmatic styles. Scape: Slender, leafless, 1 -flowered, 2 to 5 in. high. Leaf: Clover-like, of 3 leaflets, on long petioles from scaly, creeping rootstock.

Preferred Habitat-Cold, damp woods.

Flowering Season-May-July.

Distribution-Nova Scotia and Manitoba, southward to North Carolina. Also a native of Europe.

Clumps of these delicate little pinkish blossoms and abundant leaves, cuddled close to the cold earth of northern forests, usually conceal near the dry leaves or moss from which they spring blind flowers that never open-cleistogamous the botanists call them-flowers that lack petals, as if they were immature buds; that lack odor, nectar, and entrance; yet they are perfectly mature, self-fertilized, and abundantly fruitful. Fifty-five genera of plants contain one or more species on which these peculiar products are found, the pea family having more than any other, although violets offer perhaps the most familiar instance to most of us. 
Many of these species bury their offspring below ground; but the wood-sorrel bears its blind flowers nodding from the top of a curved scape at the base of the plant, where we can readily find them. By having no petals, and other features assumed by an ordinary flower to attract insects, and chiefly in saving pollen, they produce seed with literally the closest economy. It is estimated that the average blind flower of the wood-sorrel does its work with four hundred pollen grains, while the prodigal peony scatters with the help of wind and insect visitors more than three and a half millions!

As self-fertilization is impossible, the showy blossoms of the wood-sorrel are a necessity not a luxury; for the insects must not be allowed to overlook them.

Every child knows how the wood-sorrel "goes to sleep" by drooping its three leaflets until they touch back to back at evening, regaining the horizontal at sunrise-a performance most scientists now agree protects the peculiarly sensitive leaf from cold by radiation. During the day as well, seedling, scape, and leaves go through some interesting movements, closely followed by Darwin in his "Power of Movement in Plants," which should be read by all interested.

Oxalis, the Greek for sour, applies to all sorrels because of their acid juice; but acetosella = vinegar salt, the specific name of this plant, indicates that from it druggists obtain salt of lemons. Twenty pounds of leaves yield between two and three ounces of oxalic acid by crystallization. Names locally given the plant in the Old World are wood sour or sower, cuckoo's meat, sour trefoil, and shamrock-for this is St. Patrick's own flower, the true shamrock of the ancient Irish, some claim. Alleluia, another folk-name, refers to the joyousness of the Easter season, when the plant comes into bloom in England.

\section{Violet Wood-sorrel}

\section{Oxalis violacea}

Flowers-Pinkish purple, lavender, or pale magenta; less than $1 \mathrm{in.}$ long; borne on slender stems in umbels or forking clusters, each containing from 3 to 12 flowers. Calyx of 5 obtuse sepals; 5 petals; 10 ( 5 longer, 5 shorter) stamens; 5 styles persistent above 5-celled ovary. Stem: From brownish, scaly bulb 4 to 9 in. high. Leaves: About 1 in. wide, compounded of 3 rounded, clover-like leaflets with prominent midrib borne at end of slender petioles, springing from root.

Preferred Habitat—Rocky and sandy woods. 
Flowering Season-May-June.

Distribution-Northern United States to Rocky Mountains, south to Florida and New Mexico; more abundant southward.

Beauty of leaf and blossom is not the only attraction possessed by this charming little plant. As a family the wood-sorrels have great interest for botanists since Darwin devoted such exhaustive study to their power of movement, and many other scientists have described the several forms assumed by perfect flowers of the same species to secure cross-fertilization. Some members of the clan also bear blind flowers, which have been described in the account of the white wood-sorrel. Even the rudimentary leaves of the seedlings "go to sleep" at evening, and during the day are in constant movement up and down. The stems, too, are restless; and as for the mature leaves, every child knows how they droop their three leaflets back to back against the stem at evening, elevating them to the perfect horizontal again by day. Extreme sensitiveness to light has been thought to be the true explanation of so much activity, and yet this is not a satisfactory theory in many cases. It is certain that drooping leaves suffer far less from frost than those whose upper surfaces are flatly exposed to the zenith. This view that the sleep of leaves saves them from being chilled at night by radiation is Darwin's own, supported by innumerable experiments; and probably it would have been advanced by Linnaeus, too, since so many of his observations in "Somnus Plantarum" verify the theory, had the principle of radiation been discovered in his day. 


\section{GERANIUM FAMILY (Geraniaceae)}

Wild or Spotted Geranium or Crane's-Bill; Alum-root

\section{Geranium maculatum}

Flowers-Pale magenta, purplish pink, or lavender, regular, 1 to $1-1 / 2$ in. broad, solitary or a pair, borne on elongated peduncles, generally with pair of leaves at their base. Calyx of 5 lapping, pointed sepals; 5 petals, woolly at base; 10 stamens; 1 pistil with 5 styles. Fruit: A slender capsule pointed like a crane's bill. In maturity it ejects seeds elastically far from the parent plant. Stem: 1 to $2 \mathrm{ft}$. high, hairy, slender, simple or branching above. Leaves: Older ones sometimes spotted with white; basal ones 3 to $6 \mathrm{in}$. wide, 3 to 5 parted, variously cleft and toothed; 2 stem leaves opposite.

Preferred Habitat-Open woods, thickets, and shady roadsides.

Flowering Season-April-July.

Distribution—Newfoundland to Georgia, and westward a thousand miles.

Sprengel, who was the first to exalt flowers above the level of mere botanical specimens, had his attention led to the intimate relationship existing between plants and insects by studying out the meaning of the hairy corolla of the common Wild Geranium of Germany (G. sylvaticum), being convinced, as he wrote in 1787 , that "the wise Author of Nature has not made even a single hair without a definite design." A hundred years before, Nehemias Grew had said that it was neces- 
sary for pollen to reach the stigma of a flower in order that it might set fertile seed; and Linnaeus had to come to his aid with conclusive evidence to convince a doubting world that this was true. Sprengel made the next step forward, but his writings lay neglected over seventy years because he advanced the then incredible and only partially true statement that a flower is fertilized by insects which carry its pollen from its anthers to its stigma. In spite of his discoveries that the hairs inside the geranium's corolla protect its nectar from rain for the insect's benefit, just as eyebrows keep perspiration from falling into the eye; that most flowers which secrete nectar have what he termed "honey guides"-spots of bright color, heavy veining, or some such pathfinder on the petals-in spite of the most patient and scientific research that shed great light on natural selection a half-century before Darwin advanced the theory, he left it for the author of "The Origin of Species" to show that cross-fertilization-the transfer of pollen from one blossom to another, not from anthers to stigma of the same flower-is the great end to which so much marvellous mechanism is chiefly adapted. Cross-fertilized blossoms defeat self-fertilized flowers in the struggle for existence.

No wonder Sprengel's theory was disproved by his scornful contemporaries in the very case of his Wild Geranium, which sheds its pollen before it has developed a stigma to receive any; therefore no insect that had not brought pollen from an earlier bloom could possibly fertilize this flower. How amazing that he did not see this! Our common wild crane's-bill, which also has lost the power to fertilize itself, not only ripens first the outer, then the inner, row of anthers, but actually drops them off after their pollen has been removed, to overcome the barest chance of self-fertilization as the stigmas become receptive. This is the geranium's and many other flowers' method to compel cross-fertilization by insects. In cold, stormy, cloudy weather a geranium blossom may remain in the male stage several days before becoming female; while on a warm, sunny day, when plenty of insects are flying, the change sometimes takes place in a few hours. Among others, the common sulphur or puddle butterfly, that sits in swarms on muddy roads and makes the clover fields gay with its bright little wings, pilfers nectar from the geranium without bringing its long tongue in contact with the pollen. Neither do the smaller bees and flies which alight on the petals necessarily come in contact with the anthers and stigmas. Doubtless the larger bees are the flowers' true benefactors.

The so-called geraniums in cultivation are pelargoniums, strictly speaking.

Herb Robert; Red Robin; Red Shanks; Dragon's Blood 
Flowers-P'urplish rose, about $1 / 2 \mathrm{in}$. across, borne chiefly in pairs on slender peduncles. Five sepals and petals; stamens 10; pistil with 5 styles. Stem: Weak, slender, much branched, forked, and spreading, slightly hairy, 6 to $18 \mathrm{in.} \mathrm{high.}$ Leaves: Strongly scented, opposite, thin, of 3 divisions, much subdivided and cleft. Fruit: Capsular, clastic, the beak 1 in. long, awn-pointed.

Preferred Habitat-Rocky, moist woods and shady roadsides.

Flowering Season-May-October.

Distribution-Nova Scotia to Pennsylvania, and westward to Missouri.

Who was the Robert for whom this his "holy herb" was named? Many suppose that he was St. Robert, a Benedictine monk, to whom the twenty-ninth of April-the day the plant comes into flower in Europe-is dedicated. Others assert that Robert Duke of Normandy, for whom the "Ortus Sanitatis," a standard medical guide for some hundred of years, was written, is the man honored; and since there is now no way of deciding the mooted question, we may take our choice.

Only when the stems are young are they green; later the plant well earns the name of Red Shanks, and when its leaves show crimson stains, of Dragon's Blood.

At any time the herb gives forth a disagreeable odor, but especially when its leaves and stem have been crushed until they emit a resinous secretion once an alleged cure for the plague. 


\section{MILKWORT FAMILY (Polygalaceae)}

Fringed Milkwort or Polygala; Flowering Wintergreen; Gay Wings

Polygala paucifolia

Flowers-Purplish rose, rarely white, showy, over $1 / 2$ in. long, from 1 to 4 on short, slender peduncles from among upper leaves. Calyx of 5 unequal sepals, of which 2 are wing-like and highly colored like petals. Corolla irregular, its crest finely fringed; 6 stamens; 1 pistil. Also pale, pouch-like, cleistogamous flowers underground. Stem: Prostrate, 6 to 15 in. long, slender, from creeping rootstock, sending up flowering shoots 4 to $7 \mathrm{in}$. high. Leaves: Clustered at summit, oblong, or pointed egg-shaped, 1-1/2 in. long or less; those on lower part of shoots scale-like.

Preferred Habitat-Moist, rich woods, pine lands, light soil.

Flowering Season-May-July.

Distribution-Northern Canada, southward and westward to Georgia and Illinois.

Gay companies of these charming, bright little blossoms hidden away in the woods suggest a swarm of tiny mauve butterflies that have settled among the wintergreen leaves. Unlike the common milkwort and many of its kin that grow in clover-like heads, each one of the gay wings has beauty enough to stand alone. Its oddity of structure, its lovely color and enticing fringe, lead one to suspect it of extraordinary desire to woo some insect that will carry its pollen from blossom to 
blossom and so enable the plant to produce cross-fertilized seed to counteract the evil tendencies resulting from the more prolific self-fertilized cleistogamous flowers buried in the ground below.

\section{Common, Field, or Purple Milkwort; P'urple Polygala}

\section{Polygala sanguinea (P. viridescens)}

Flowers-Numerous, very small, variable; bright magenta pink, or almost red, or pale to whiteness, or greenish, clustered in a globular clover-like head, gradually lengthening to a cylindric spike. Stem: 6 to 15 in. high, smooth, branched above, leafy. Leaves: Alternate, narrowly oblong, entire.

Preferred Habitat-Fields and meadows, moist or sandy.

Flowering Season-June-September.

Distribution-Southern Canada to North Carolina, westward to the Mississippi.

When these bright clover-like heads and the inconspicuous greenish ones grow together, the difference between them is so striking it is no wonder Linnaeus thought they were borne by two distinct species, Sanguinea and viridescens, whereas they are now known to be merely two forms of the same flower. At first glance one might mistake the irregular little blossom for a member of the pea family; two of the five very unequal sepals — not petals - are colored wings. These bright-hued calyx-parts overlap around the flower-head like tiles on a roof. Within each pair of wings are three petals united into a tube, split on the back, to expose the vital organs to contact with the bee, the milkwort's best friend.

Plants of this genus were named polygala, the Greek for much milk, not because they have milky juice-for it is bitter and clear-but because feeding on them is supposed to increase the flow of cattle's milk. 


\section{TOUCH-ME-NOT FAMILY (Balsaminaceae)}

Jewel-weed; Spotted Touch-me-not; Silver Cap; Wild Balsam; Lady's Eardrops; Snap Weed; Wild Lady's Slipper

Impatiens biflora (I. fulva)

Flowers-Orange yellow, spotted with reddish brown, irregular, 1 in. long or less, horizontal, 2 to 4 pendent by slender footstalks on a long peduncle from leaf axils. Sepals, 3, colored; 1 large, sac-shaped, contracted into a slender incurved spur and 2-toothed at apex; 2 other sepals small. Petals, 3; 2 of them 2-cleft into dissimilar lobes; 5 short stamens, 1 pistil. Stem: 2 to $5 \mathrm{ft}$. high, smooth, branched, colored, succulent. Leaves: Alternate, thin, pale beneath, ovate coarsely toothed, petioled. Fruit: An oblong capsule, its 5 valves opening elastically to expel the seeds.

Preferred Habitat-Beside streams, ponds, ditches; moist ground.

Flowering Season-July-October.

Distribution-Nova Scotia to Oregon, south to Missouri and Florida.

These exquisite, bright flowers, hanging at a horizontal, like jewels from a lady's ear, may be responsible for the plant's folk-name; but whoever is abroad early on a dewy morning, or after a shower, and finds notched edges of the drooping leaves hung with scintillating gems, dancing, sparkling in the sunshine, sees still another reason for naming this the Jewel-weed. In a brook, pond, spring, or wayside trough, which can never be far from its haunts, dip a spray of the plant to trans- 
form the leaves into glistening silver. They shed water much as the nasturtiums do.

When the tiny ruby-throated humming bird flashes northward out of the tropics to spend the summer, where can he hope to find nectar so deeply secreted that not even the long-tongued bumblebee may rob him of it all? Beyond the bird's bill his tongue can be run out and around curves no other creature can reach. Now the early-blooming columbine, its slender cornucopias brimming with sweets, welcomes the messenger whose needle-like bill will carry pollen from flower to flower; presently the coral honeysuckle and the scarlet painted-cup attract him by wearing his favorite color; next the jewel-weed hangs horns of plenty to lure his eye; and the trumpet vine and cardinal flower continue to feed him successively in Nature's garden; albeit cannas, nasturtiums, salvia, gladioli, and such deep, irregular showy flowers in men's flower beds sometimes lure him away.

Faniliar as we may be with the nervous little seed-pods of the touch-me-not, which children ever love to pop and see the seeds fly, as they do from balsam pods in grandmother's garden, they still startle with the suddenness of their volley. Touch the delicate hair-trigger at the end of a capsule, and the lightning response of the flying seeds makes one jump. They sometimes land four feet away. At this rate of progress a year, and with the other odds against which all plants have to contend, how many generations must it take to fringe even one mill pond with jewel-weed; yet this is rapid transit indeed compared with many of Nature's processes. The plant is a conspicuous sufferer from the dodder.

The Pale Touch-me-not (I. aurea)—I. pallida of Gray_most abundant northward, a larger, stouter species found in similar situations, but with paler yellow flowers only sparingly dotted if at all, has its broader sac-shaped sepal abruptly contracted into a short, notched, but not incurved spur. It shares its sister's popular names. 


\section{BUCKTHORN FAMILY (Rhamnaceae)}

New Jersey Tea; Wild Snowball; Red-root

Ceanothus americanus

Flowers-Small, white, on white pedicels, crowded in dense, oblong, terminal clusters. Calyx white, hemispheric, 5-lobed; 5 petals, hooded and long-clawed; 5 stamens with long filaments; style short, 3-cleft. Stems: Shrubby, 1 to $3 \mathrm{ft}$. high, usually several, from a deep reddish root. Leaves: Alternate, ovate-oblong, acute at tip, finely saw-edged, 3-nerved, on short petioles.

Preferred Habitat-Dry, open woods and thickets.

Flowering Season-May-July.

Distribution-Ontario south and west to the Gulf of Mexico.

Light, feathery clusters of white little flowers crowded on the twigs of this low shrub interested thrifty colonial housewives of Revolutionary days not at all; the tender, young, rusty, downy leaves were what they sought to dry as a substitute for imported tea. Doubtless the thought that they were thereby evading George the Third's tax and brewing patriotism in every kettleful added a sweetness to the home-made beverage that sugar itself could not impart. The American troops were glad enough to use New Jersey Tea throughout the war. A nankeen or cinnamon-colored dye is made from the reddish root. 


\section{MALLOW FAMILY (Malvaceae)}

Swamp Rose-mallow; Mallow Rose

\section{Hibiscus Moscheutos}

Flowers-Very large, clear rose pink, sometimes white, often with crimson centre, 4 to $7 \mathrm{in}$. across, solitary, or clustered on peduncles at summit of stems. Calyx 5-cleft, subtended by numerous narrow bractlets; 5 large, veined petals; stamens united into a valvular column bearing anthers on the outside for much of its length; 1 pistil partly enclosed in the column, and with 5 button-tipped stigmatic branches above. Stem: 4 to $7 \mathrm{ft}$. tall, stout, from perennial root. Leaves: 3 to 7 in. long, tapering, pointed, egg-shaped, densely white, downy beneath; lower leaves, or sometimes all, lobed at middle.

Preferred Habitat—Brackish marshes, riversides, lake shores, saline situations.

Flowering Season-August-September.

Distribution-Massachusetts to the Gulf of Mexico, westward to Louisiana; found locally in the interior, but chiefly along Atlantic seaboard.

Stately ranks of these magnificent flowers, growing among the tall sedges and "cat-tails" of the marshes, make the most insensate traveller exclaim at their amazing loveliness. To reach them one must don rubber boots and risk sudden seats in the slippery ooze; nevertheless, with spade in hand to give one support, it is well worth while to seek them out and dig up some roots to transplant to the garden. 
Here, strange to say, without salt soil or more water than the average garden receives from showers and hose, this handsomest of our wild flowers soon makes itself delightfully at home under cultivation. Such good, deep earth, well enriched and moistened, as the hollyhock thrives in, suits it perfectly. Now we have a better opportunity to note how the bees suck the five nectaries at the base of the petals, and collect the abundant pollen of the newly-opened flowers, which they perforce transfer to the five button-shaped stigmas intentionally impeding the entrance to older blossoms. Only its cousin the hollyhock, a native of China, can vie with the rose-mallow's decorative splendor among the shrubbery; and the Rose of China (Hibiscus Rosa-Sinensis), cultivated in greenhouses here, eclipse it in the beauty of the individual blossom. This latter flower, whose superb scarlet corolla stains black, is employed by the Chinese married women, it is said, to discolor their teeth; but in the West Indies it sinks to even greater ignominy as a dauber for blacking shoes!

Marsh Mallow (Althaea officinalis), a name frequently misapplied to the Swamp Rose-mallow, is properly given to a much smaller pink flower, measuring only an inch and a half across at the most, and a far rarer one, being a naturalized immigrant from Europe found only in the salt marshes from the Massachusetts coast to New York. It is also known as Wymote. This is a bushy, leafy plant, two to four feet high, and covered with velvety down as a protection against the clogging of its pores by the moisture arising from its wet retreats. Plants that live in swamps must "perspire" freely and keep their pores open. From the Marsh Mallow's thick roots the mucilage used in confectionery is obtained, a soothing demulcent long esteemed in medicine. 


\section{ST. JOHN'S-WORT FAMILY (Hypericaceae)}

Common St. John's-wort

Hypericum perforatum

Flowers-Bright yellow, 1 in. across or less, several or many in terminal clusters. Calyx of 5 lance-shaped sepals; 5 petals dotted with black; numerous stamens in 3 sets; 3 styles. Stem: 1 to $2 \mathrm{ft}$. high, erect, much branched. Leaves: Small, opposite, oblong, more or less black-dotted.

Preferred Habitat-Fields, waste lands, roadsides.

Flowering Season-June-September.

Distribution-Throughout our area, except the extreme North; Europe and Asia.

"Gathered upon a Friday, in the hour of Jupiter when he comes to his operation, so gathered, or borne, or hung upon the neck, it mightily helps to drive away all phantastical spirits." These are the blossoms which have been hung in the windows of European peasants for ages on St. John's eve, to avert the evil eye and the spells of the spirits of darkness. "Devil chaser" its Italian name signifies. To cure demoniacs, to ward off destruction by lightning, to reveal the presence of witches, and to expose their nefarious practices, are some of the virtues ascribed to this plant, which superstitious farmers have spared from the scythe and encouraged to grow near their houses until it has become, even in this land of liberty, a troublesome weed at times. "The flower gets its name," says F. Schuyler Mathews, "from 
the superstition that on St. John's day, the 24th of June, the dew which fell on the plant the evening before was efficacious in preserving the eyes from disease. So the plant was collected, dipped in oil, and thus transformed into a balm for every wound." Here it is a naturalized immigrant, not a native. A blooming plant, usually with many sterile shoots about its base, has an unkempt, untidy look; the seed capsules and the brown petals of withered flowers remaining among the bright yellow buds through a long season.

The Shrubby St. John's-wort (H. prolificum) bears yellow blossoms, about half an inch across, which are provided with stamens so numerous, the many flowered terminal clusters have a soft, feathery effect. In the axils of the oblong, opposite leaves are tufts of smaller ones, the stout stems being often concealed under a wealth of foliage. Sandy or rocky places from New Jersey southward best suit this low, dense, diffusely branched shrub which blooms prolifically from July to September.

Farther north, and westward to Iowa, the Great or Giant St. John's-wort ( $\mathrm{H}$. Ascyron) brightens the banks of streams at midsummer with large blossoms, each on a long footstalk in a few-flowered cluster. 


\section{ROCKROSE FAMILY (Cistaceae)}

Long-branched Frost-weed; Frost-flower; Frost-wort; Canadian Rockrose

\section{Helianthemum canadense}

Flowers-Solitary, or rarely 2; about $1 \mathrm{in.}$ across, 5-parted, with showy yellow petals; the 5 unequal sepals hairy. Also abundant small flowers lacking petals, produced from the axils later. Stem: Erect, 3 in. to $2 \mathrm{ft}$. high; at first simple, later with elongated branches. Leaves: Alternate, oblong, almost seated on stem.

Preferred Habitat-Dry fields, sandy or rocky soil.

Flowering Season-Petal-bearing flowers, May-July.

Distribution-New England to the Carolinas, westward to Wisconsin and Kentucky.

When the stubble in the dry fields is white some cold November morning, comparatively few notice the ice crystals, like specks of glistening quartz, at the base of the stems of this plant. The similar Hoary Frost-weed (H. majus), whose showy flowers appear in clusters at the hoary stem's summit in June and July, also bears them. Often this ice formation assumes exquisite feathery, whimsical forms, bursting the bark asunder where an astonishing quantity of sap gushes forth and freezes. Indeed, so much sap sometimes goes to the making of this crystal flower, that it would seem as if an extra reservoir in the soil must pump some up to supply it with its large fantastic corolla. 


\section{VIOLET FAMILY (Violaceae)}

Blue and Purple Violets

Lacking perfume only to be a perfectly satisfying flower, the Common Purple, Meadow, or Hooded Blue Violet (V. cucullata) has nevertheless established itself in the hearts of the people from the Arctic to the Gulf as no sweet-scented, showy, hothouse exotic has ever done. Royal in color as in lavish profusion, it blossoms everywhere-in woods, waysides, meadows, and marshes, but always in finer form in cool, shady dells; with longer flowering scapes in meadow bogs; and with longer leaves than wide in swampy woodlands. The heart-shaped, saw-edged leaves, folded toward the centre when newly put forth, and the five-petalled, bluish-purple, golden-hearted blossom are too familiar for more detailed description. From the three-cornered stars of the elastic capsules, the seeds are scattered abroad.

In shale and sandy soil, even in the gravel of hillsides, one finds the narrowly divided, finely cut leaves and the bicolored beardless blossom of the Bird's-foot Violet (V. pedata), pale bluish purple on the lower petals, dark purple on one or two upper ones, and with a heart of gold. The large, velvety, pansy-like blossom and the unusual foliage which rises in rather dense tufts are sufficient to distinguish the plant from its numerous kin. This species produces no cleistogamous or blind flowers. Frequently the Bird's-foot Violet blooms a second time, in autumn, a delightful eccentricity of this family. The spur of its lower petal is long and very slender, and, as might be expected, the longest-tongued bees and butterflies are its most frequent visitors. These receive the pollen on the base of the proboscis. 
In course of time the lovely English, March, or Sweet Violet (V. odorata), which has escaped from gardens, and which is now rapidly increasing with the help of seed and rumners on the Atlantic and the Pacific coasts, may be established among our wild flowers. No blossom figures so prominently in European literature. In France, it has even entered the political field since Napoleon's day. Yale University has adopted the violet for its own especial flower, although it is the corn-flower, or bachelor's button (Centaurea cyanus) that is the true Yale blue. Sprengel, who made a most elaborate study of the violet, condensed the result of his research into the following questions and answers, which are given here because much that he says applies to our own native species, which have been too little studied in the modern scientific spirit:

"1. Why is the flower situated on a long stalk which is upright, but curved downward at the free end? In order that it may hang down; which, firstly, prevents rain from obtaining access to the nectar; and, secondly, places the stamens in such a position that the pollen falls into the open space between the pistil and the free ends of the stamens. If the flower were upright, the pollen would fall into the space between the base of the stamen and the base of the pistil, and would not come in contact with the bee.

"2. Why does the pollen differ from that of most other insect-fertilized flowers? In most of such flowers the insects themselves remove the pollen from the anthers, and it is therefore important that the pollen should not easily be detached and carried away by the wind. In the present case, on the contrary, it is desirable that it should be looser and drier, so that it may easily fall into the space between the stamens and the pistil. If it remained attached to the anther, it would not be touched by the bee, and the flower would remain unfertilized.

" 3 . Why is the base of the style so thin? In order that the bee may be more easily able to bend the style.

"4. Why is the base of the style bent? For the same reason. The result of the curvature is that the pistil is much more easily bent than would be the case if the style were straight.

"5. Finally, why does the membranous termination of the upper filament overlap the corresponding portions of the two middle stamens? Because this enables the bee to move the pistil and thereby to set free the pollen more easily than would be the case under the reverse arrangement." 
Fine hairs on the erect, leafy, usually single stem of the Downy Yellow Violet (V. pubescens), whose dark veined, bright yellow petals gleam in dry woods in April and May, easily distinguish it from the Smooth Yellow Violet (V. scabriuscula), formerly considered a mere variety in spite of its being an earlier bloomer, a lover of moisture, and well equipped with basal leaves at flowering time, which the downy species is not. Moreover, it bears a paler blossom, more coarsely dentate leaves, often decidedly taper-pointed, and usually several stems together.

Bryant, whose botanical lore did not always keep step with his Muse, wrote of the Yellow Violet as the first spring flower, because he found it "by the snowbank's edges cold," one April day, when the hepaticas about his home at Roslyn, Long Island, had doubtless been in bloom a month.

"Of all her train the hands of Spring

First plant thee in the watery mould,"

he wrote, regardless of the fact that the round-leaved violet's preferences are for dry, wooded, or rocky hillsides. Mueller believed that all violets were originally yellow, not white, after they developed from the green stage.

\section{White Violets}

Three small-flowered, white, purple-veined, and almost beardless species which prefer to dwell in moist meadows, damp, mossy places, and along the borders of streams, are the Lance-leaved Violet (V. lanceolata), the Primrose-leaved Violet (V. primulifolia), and the Sweet White Violet (V. blanda), whose leaves show successive gradations from the narrow, tapering, smooth, long-petioled blades of the first to the oval form of the second and the almost circular, cordate leaf of the delicately fragrant, little white blanda, the dearest violet of all. Inasmuch as these are short-spurred species, requiring no effort for bees to drain their nectaries, no footholds in the form of beards on the side petals are provided for them. The purple veinings show the stupidest visitor the path to the sweets. 


\section{EVENING PRIMROSE FAMILY (Onagraceae)}

Great or Spiked Willow-herb; Fire-weed

Epilobium angustifolium (Chamaenerion angustifolium)

Flowers-Magenta or pink, sometimes pale, or rarely white, more or less than 1 in. across, in an elongated, terminal, spike-like raceme. Calyx tubular, narrow, in 4 segments; 4 rounded, spreading petals; 8 stamens; 1 pistil, hairy at base; the stigma 4-lobed. Stem: 2 to $8 \mathrm{ft}$. high, simple, smooth, leafy. Leaves: Narrow, tapering, willow-like, 2 to 6 in. long. Fruit: A slender, curved, violet-tinted capsule, from 2 to $3 \mathrm{in}$. long, containing numerous seeds attached to tufts of fluffy, white, silky threads.

Preferred Habitat-Dry soil, fields, roadsides, especially in burnt-over districts.

Flowering Season-June-September.

Distribution-From Atlantic to Pacific, with few interruptions; British Possessions and United States southward to the Carolinas and Arizona. Also Europe and Asia.

Spikes of these beautiful brilliant flowers towering upward above dry soil, particularly where the woodsman's axe and forest fires have devastated the landscape, illustrate Nature's abhorrence of ugliness. Other kindly plants have earned the name of fireweed, but none so quickly beautifies the blackened clearings of the pioneer, nor blossoms over the charred trail in the wake of the locomotive. Whole 
mountainsides in Alaska are dyed crimson with it. Beginning at the bottom of the long spike, the flowers open in slow succession upward throughout the summer, leaving behind the attractive seed-vessels, which, splitting lengthwise in September, send adrift white silky tufts attached to seeds that will one day cover far distant wastes with beauty. Almost perfect rosettes, made by the young plants, are met with on one's winter walks.

Evening Primrose; Night Willow-herb

\section{Oenothera biennis}

Flowers-Yellow, fragrant, opening at evening, 1 to $2 \mathrm{in}$. across, borne in terminal leafy-bracted spikes. Calyx tube slender, elongated, gradually enlarged at throat, the 4-pointed lobes bent backward; corolla of 4 spreading petals; 8 stamens; 1 pistil; the stigma 4-cleft. Stem: Erect, wand-like, or branched, 1 to $5 \mathrm{ft}$. tall, rarely higher, leafy. Leaves: Alternate, lance-shaped, mostly seated on stem, entire, or obscurely toothed.

Preferred Habitat—Roadsides, dry fields, thickets, fence-corners.

Flowering Season-June-October.

Distribution-Labrador to the Gulf of Mexico, west to the Rocky Mountains.

Like a ball-room beauty, the Evening Primrose has a jaded, bedraggled appearance by day when we meet it by the dusty roadside, its erect buds, fading flowers from last night's revelry, wilted ones of previous dissipations, and hairy oblong capsules, all crowded together among the willow-like leaves at the top of the rank-growing plant. But at sunset a bud begins to expand its delicate petals slowly, timidlynot suddenly and with a pop, as the evening primrose of the garden does.

Now, its fragrance, that has been only faintly perceptible during the day, becomes increasingly powerful. Why these blandishments at such an hour? Because at dusk, when sphinx moths, large and small, begin to fly, the primrose's special benefactors are abroad. All these moths, whose length of tongue has kept pace with the development of the tubes of certain white and yellow flowers dependent on their ministrations, find such glowing like miniature moons for their special benefit, when blossoms of other hues have melted into the deepening darkness. If such have fragrance, they prepare to shed it now. Nectar is secreted in tubes so deep and slender that none but the moths' long tongues can drain the last drop. An exquisite, little, rose-pink twilight flyer, his wings bordered with yellow, flut- 
ters in ecstasy above the Evening Primrose's freshly opened flowers, transferring in his rapid flight some of their abundant, sticky pollen that hangs like a necklace from the outstretched filaments. By day one may occasionally find a little fellow asleep in a wilted blossom, which serves him as a tent, under whose flaps the brightest bird eye rarely detects a dinner. After a single night's dissipation the corolla wilts, hangs a while, then drops from the maturing capsule as if severed with a sharp knife. Few flowers, sometimes only one opens on a spike on a given evening - a plan to increase the chances of cross-fertilization between distinct plants; but there is a very long succession of bloom. If a flower has not been pollenized during the night it remains open a while in the morning. Bumblebees now hurry in, and an occasional humming bird takes a sip of nectar. Toward the end of summer, when so much seed has been set that the flower can afford to be generous, it distinctly changes its habit and keeps open house all day. 
GINSENG FAMILY (Araliaceae)

Spikenard; Indian Root; Spignet

Aralia racemosa

Flowers-Greenish white, small, 5-parted, mostly imperfect, in a drooping compound raceme of rounded clusters. Stem: 3 to $6 \mathrm{ft}$. high, branches spreading. Roots: Large, thick, fragrant. Leaves: Compounded of heart-shaped, sharply tapering, saw-edged leaflets from 2 to $5 \mathrm{in}$. long, often downy underneath. Lower leaves often enormous. Fruit: Dark reddish-brown berries.

Preferred Habitat-Rich open woods, wayside thickets, light soil.

Flowering Season-July-August.

Distribution-New Brunswick to Georgia, west to the Mississippi.

A striking, decorative plant, once much sought after for its medicinal virtuesstill another herb with which old women delight to dose their victims for any malady from a cold to a carbuncle. Quite a different plant, but a relative, is the one with hairy spike-like shoots from its fragrant roots, from which the "very precious" ointment poured by Mary upon the Saviour's head was made. The nard, an Indian product from that plant, which is still found growing on the distant Himalayas, could then be imported into Palestine only by the rich. 
How certain of the winter birds gormandize on the resinous, spicy little berries! A flock of juncos will strip the fruit from every spikenard in the neighborhood the first day it arrives from the North.

It should be understood that the Wild Spikenard, or False Solomon's Seal, has not the remotest connection with this tribe of plants.

The Wild or False Sarsaparilla (A. nudicaulis), so common in woods, hillsides, and thickets, shelters its three spreading umbels of greenish-white flowers in May and June beneath a canopy formed by a large, solitary, compound leaf. The aromatic roots, which run horizontally sometimes three feet or more through the soil, send up a very short, smooth proper stem which lifts a tall leafstalk and a shorter, naked flower-stalk. The single large leaf, of exquisite bronzy tints when young, is compounded of from three to five oval, toothed leaflets on each of its three divisions.

While the true sarsaparilla of medicine should come from a quite different herb that flourishes in Mexico and South America, this one furnishes a commercial substitute enormously used as a blood purifier and cooling summer drink. Burrowing rabbits delight to nibble the long, slender, fragrant roots. 


\section{PARSLEY FAMILY (Umbelliferae)}

Wild or Field Parsnip; Madnep; Tank

Pastinaca sativa

Flowers-Dull or greenish yellow, small, without involucre or involucels; borne in 7 to 15 rayed umbels, 2 to $6 \mathrm{in}$. across. Stem: 2 to $5 \mathrm{ft}$. tall, stout, smooth, branching, grooved, from a long, conic, fleshy, strong-scented root. Leaves: Compounded (pinnately), of several pairs of oval, lobed, or cut sharply toothed leaflets; the petioled lower leaves often 1-1/2 ft. long.

Preferred Habitat - Waste places, roadsides, fields.

Flowering Season-June-September.

Distribution-Common throughout nearly all parts of the United States and Canada. Europe.

Men are not the only creatures who feed upon such of the umbel-bearing plants as are innocent-parsnips, celery, parsley, carrots, caraway, and fennel, among others; and even those which contain properties that are poisonous to highly organized men and beasts, afford harmless food for insects. Pliny says that parsnips, which were cultivated beyond the Rhine in the days of Tiberius, were brought to Rome annually to please the emperor's exacting palate, yet this same plant, which has overrun two continents, in its wild state (when its leaves are a paler yellowish green than under cultivation) often proves poisonous. A strongly 
acrid juice in the very tough stem causes intelligent cattle to let it alone-precisely the object desired.

Wild Carrot; Queen Anne's Lace; Bird's-nest

\section{Daucus Carota}

Flowers - Small, of unequal sizes (polygamous), white, rarely pinkish gray, 5-parted, in a compound, flat, circular, umbel, the central floret often dark crimson; the umbels very concave in fruit. An involucre of narrow, pinnately cut bracts. Stem: 1 to $3 \mathrm{ft}$. high, with stiff hairs; from a deep, fleshy, conic root. Leaves: Cut into fine, fringy divisions; upper ones smaller and less dissected.

Preferred Habitat—Waste lands, fields, roadsides.

Flowering Season-June-September.

Distribution-Eastern half of United States and Canada. Europe and Asia.

A pest to farmers, a joy to the flower-lover, and a welcome signal for refreshment to hosts of flies, beetles, bees, and wasps, especially to the paper-nest builders, the sprangly wild carrot lifts its fringy foliage and exquisite lacy blossoms above the dry soil of three continents. From Europe it has come to spread its delicate wheels over our summer landscape, until whole fields are whitened by them east of the Mississippi. Having proved fittest in the struggle for survival in the fiercer competition of plants in the over-cultivated Old World, it takes its course of empire westward year by year, finding most favorable conditions for colonizing in our vast, uncultivated area; and the less aggressive, native occupants of our soil are only too readily crowded out. Would that the advocates of unrestricted immigration of foreign peasants studied the parallel examples among floral invaders!

Still another fiction is that the cultivated carrot, introduced to England by the Dutch in Queen Elizabeth's reign, was derived from this wild species. Miller, the celebrated English botanist and gardener, among many others, has disproved this statement by utterly failing again and again to produce an edible vegetable from this wild root. When cultivation of the garden carrot lapses for a few generations, it reverts to the ancestral type-a species quite distinct from Daucus Carota. 


\section{DOGWOOD FAMILY (Cornaceae)}

Flowering Dogwood

Cornus florida

Flowers-(Apparently) large, white or pinkish, the four conspicuous parts simulating petals, notched at the top, being really bracts of an involucre below the true flowers, clustered in the centre, which are very small, greenish yellow, 4-parted, perfect. Stem: A large shrub or small tree, wood hard, bark rough. Leaves: Opposite oval, entire-edged, petioled, paler underneath. Fruit: Clusters of eggshaped scarlet berries, tipped with the persistent calyx.

Preferred Habitat—Woodlands, rocky thickets, wooded roadsides.

Flowering Season-April-June.

Distribution-Maine to Florida, west to Ontario and Texas.

Has Nature's garden a more decorative ornament than the Flowering Dogwood, whose spreading flattened branches whiten the woodland borders in May as if an untimely snowstorm had come down upon them, and in autumn paint the landscape with glorious crimson, scarlet, and gold, dulled by comparison only with the clusters of vivid red berries among the foliage? Little wonder that nurserymen sell enormous numbers of these small trees to be planted on lawns. The horrors of pompous monuments, urns, busts, shafts, angels, lambs, and long-drawn-out eulogies in stone in many a cemetery are mercifully concealed in part by these boughs, laden with blossoms of heavenly purity. 
"Let dead names be eternized in dead stone, But living names by living shafts be known. Plant thou a tree whose leaves shall sing Thy deeds and thee each fresh, recurrent spring."

When the Massachusetts farmers think they hear the first brown thrasher in April advising them to plant their Indian corn, reassuringly calling, "Drop it, drop itcover it up, cover it up-pull it up, pull it up, pull it up" (Thoreau), they look to the dogwood flowers to confirm the thrasher's advice before taking it.

The Low or Dwarf Cornel, or Bunchberry (C. canadensis), whose scaly stem does its best to attain a height of nine inches, bears a whorl of from four to six oval, pointed, smooth leaves at the summit. From the midst of this whorl comes a cluster of minute greenish florets, encircled by four to six large, showy, white petallike bracts, quite like a small edition of the Flowering Dogwood blossom. Tight clusters of round berries, that are lifted upward on a gradually lengthened peduncle after the flowers fade (May-July), brighten with vivid touches of scarlet, shadowy, mossy places in cool, rich woods, where the dwarf cornels, with the partridge vine, twin flower, gold thread, and fern, form the most charming of carpets.

Even more abundant is the Silky Cornel, Kinnikinnick, or Swamp Dogwood (C. Amomum) found in low, wet ground, and beside streams, from Nebraska to the Atlantic Ocean, south to Florida and north to New Brunswick. Its dull, reddish twigs, oval or oblong leaves, rounded at the base, but tapering to a point at the apex, and usually silky-downy with fine, brownish hairs underneath (to prevent the pores from clogging with vapors arising from its damp habitat); its rather compact, flat clusters of white flowers from May to July, and its bluish berries are its distinguishing features. The Indians loved to smoke its bark for its alleged tonic effect. 


\section{HEATH FAMILY (Ericaceae)}

Pipsissewa; Prince’s Pine

Chimaphila umbellata

Flowers-Flesh-colored, or pinkish, fragrant, waxy, usually with deep pink ring around centre, and the anthers colored; about 1/2 in. across; several flowers in loose, terminal cluster. Calyx 5-cleft; corolla of 5 concave, rounded, spreading petals; 10 stamens, the filaments hairy; style short, conical, with a round stigma. Stem: Trailing far along ground, creeping, or partly subterranean, sending up sterile and flowering branches 3 to $10 \mathrm{in}$. high. Leaves: Opposite or in whorls, evergreen, bright, shining, spatulate to lance-shaped, sharply saw-edged.

Preferred Habitat-Dry woods, sandy leaf mould.

Flowering Season-June-August.

Distribution-British Possessions and the United States north of Georgia from the Atlantic to the Pacific. Also Mexico, Europe, and Asia.

A lover of winter indeed (cheima $=$ winter and phileo $=$ to love) is the Prince's Pine, whose beautiful dark leaves keep their color and gloss in spite of snow and intense cold. A few yards of the trailing stem, easily ripped from the light soil of its woodland home, make a charming indoor decoration, especially when the litthe brown seed-cases remain. Few flowers are more suggestive of the woods than these shy, dainty, deliciously fragrant little blossoms. 
The Spotted Wintergreen, or Pipsissewa (C. maculata), closely resembles the Prince's P'ine, except that its slightly larger white or pinkish flowers lack the deep pink ring; and the lance-shaped leaves, with rather distant saw-teeth, are beautifully mottled with white along the veins. When we see short-lipped bees and flies about these flowers, we may be sure their pollen-covered mouths come in contact with the moist stigma on the summit of the little top-shaped style, and so effect cross-fertilization.

Indian Pipe; Ice-plant; Ghost-flower; Corpse-plant

\section{Monotropa uniflora}

Flowers-Solitary, smooth, waxy, white (rarely pink), oblong bell-shaped, nodding from the tip of a fleshy, white, scaly scape 4 to $10 \mathrm{in}$. tall. Calyx of 2 to 4 early-falling white sepals; 4 or 5 oblong, scale-like petals; 8 or 10 tawny, hairy stamens; a 5-celled, egg-shaped ovary, narrowed into the short, thick style. Leaves: None. Roots: A mass of brittle fibres, from which usually a cluster of several white scapes arises. Fruit: A 5-valved, many-seeded, erect capsule.

Preferred Habitat-Heavily shaded, moist, rich woods, especially under oak and pine trees.

Flowering Season-June-August.

Distribution-Almost throughout temperate North America.

Colorless in every part, waxy, cold, and clammy, Indian pipes rise like a company of wraiths in the dim forest that suits them well. Ghoulish parasites, uncanny saprophytes, for their matted roots prey either on the juices of living plants or on the decaying matter of dead ones, how weirdly beautiful and decorative they are! The strange plant grows also in Japan, and one can readily imagine how fascinated the native artists must be by its chaste charms.

Yet to one who can read the faces of flowers, as it were, it stands a branded sinner. Doubtless its ancestors were industrious, honest creatures, seeking their food in the soil, and digesting it with the help of leaves filled with good green matter (chlorophyll) on which virtuous vegetable life depends; but some ancestral knave elected to live by piracy, to drain the already digested food of its neighbors; so the Indian Pipe gradually lost the use of parts for which it has need no longer, until we find it to-day without color and its leaves degenerated into mere scaly bracts. 
Nature had manifold ways of illustrating the parable of the ten pieces of money. Spiritual law is natural law: "From him that hath not, even that he hath shall be taken away." Among plants as among souls, there are all degrees of backsliders. The foxglove, which is guilty of only sly, petty larceny, wears not the equivalent of the striped suit and the shaved head; nor does the mistletoe, which steals crude food from the tree, but still digests it itself, and is therefore only a dingy yellowish green. Such plants, however, as the broom-rape, Pine Sap, beech-drops, the Indian Pipe, and the dodder-which marks the lowest stage of degradation of them all-appear among their race branded with the mark of crime as surely as was Cain.

No wonder this degenerate hangs its head; no wonder it grows black with shame on being picked, as if its wickedness were only just then discovered! To think that a plant related on one side to many of the loveliest flowers in Nature's gardenthe azaleas, laurels, rhododendrons, and the bonny heather-and on the other side to the modest but no less charming wintergreen tribe, should have fallen from grace to such a depth! Its scientific name, meaning a flower once turned, describes it during only a part of its career. When the minute, innumerable seeds begin to form, it proudly raises its head erect, as if conscious that it had performed the one righteous act of its life.

Pine Sap; False Beech-drops; Yellow Bird's-nest

\section{Monotropa Hypopitis}

Flowers-Tawny, yellow, ecru, brownish pink, reddish, or bright crimson, fragrant, about 1/2 in. long; oblong bell-shaped; borne in a one-sided, terminal, slightly drooping raceme, becoming erect after maturity. Scapes: Clustered from a dense mass of fleshy, fibrous roots; 4 to $12 \mathrm{in}$. tall, scaly bracted, the bractlets resembling the sepals. Leaves: None.

Preferred Habitat-Dry woods, especially under fir, beech, and oak trees.

Flowering Season-June-October.

Distribution-Florida and Arizona, far northward into British Possessions. Europe and Asia.

Branded a sinner, through its loss of leaves and honest green coloring matter (chlorophyll), the Pine Sap stands among the disreputable gang of thieves that includes its next of kin the Indian Pipe, the broom-rape, dodder, coral-root, and 
beech-drops. Degenerates like these, although members of highly respectable, industrious, virtuous families, would appear to be as low in the vegetable kingdom as any fungus, were it not for the flowers they still bear. Petty larceny, no greater than the foxglove's at first, then greater and greater thefts, finally lead to ruin, until the pine-sap parasite either sucks its food from the roots of the trees under which it takes up its abode, or absorbs, like a ghoulish saprophyte, the products of vegetable decay. A plant that does not manufacture its own dinner has no need of chlorophyll and leaves, for assimilation of crude food can take place only in those cells which contain the vital green. This substance, universally found in plants that grub in the soil and literally sweat for their daily bread, acts also as a moderator of respiration by its absorptive influence on light, and hence allows the elimination of carbon dioxide to go on in the cells which contain it. Fungi and these degenerates which lack chlorophyll usually grow in dark, shady woods.

Wild Honeysuckle; Pink, Purple, or Wild Azalea; Pinxter-flower

\section{Rhododendron nudiflorum}

Flowers-Crimson pink, purplish or rose pink, to nearly white, 1-1/2 to 2 in. across, faintly fragrant, clustered, opening before or with the leaves, and developed from cone-like, scaly brown buds. Calyx minute, 5-parted; corolla funnelshaped, the tube narrow, hairy, with 5 regular, spreading lobes; 5 long red stamens; 1 pistil, declined, protruding. Stem: Shrubby, usually simple below, but branching above, 2 to $6 \mathrm{ft}$. high. Leaves: Usually clustered, deciduous, oblong, acute at both ends, hairy on midrib.

Preferred Habitat-Moist, rocky woods, or dry woods and thickets.

Flowering Season-April-May.

Distribution-Maine to Illinois, and southward to the Gulf.

Woods and hillsides are glowing with fragrant, rosy masses of this lovely azalea, the Pinxter-bloem or Whitsunday flower of the Dutch colonists, long before the seventh Sunday after Easter. Among our earliest exports, this hardy shrub, the Swamp Azalea, and the superb flame-colored species of the Alleghanies, were sent early in the eighteenth century to the old country, and there crossed with A. Pontica of southern Europe by the Belgian horticulturists, to whom we owe the Ghent azaleas, the final triumphs of the hybridizer, that glorify the shrubberies on our own lawns to-day. The azalea became the national flower of Flanders. These hardy species lose their leaves in winter, whereas the hothouse varieties of $\mathrm{A}$. 
Indica, a native of China and Japan, have thickish leaves, almost if not quite evergreen. A few of the latter stand our northern winters, especially the pure white variety now quite commonly planted in cemetery lots. In that delightfully enthusiastic little book, "The Garden's Story," Mr. Ellwanger says of the Ghent Azalea: "In it I find a charm presented by no other flower. Its soft tints of buff, sulphur, and primrose; its dazzling shades of apricot, salmon, orange, and vermilion are always a fresh revelation of color. They have no parallel among flowers, and exist only in opals, sunset skies, and the flush of autumn woods." Certainly American horticulturists were not clever in allowing the industry of raising these plants from our native stock to thrive on foreign soil.

From Maine to Florida and westward to Texas, chiefly near the coast, in low, wet places only need we look for the Swamp Pink or Honeysuckle, White or Clammy Azalea (Rhododendron viscosum), a more hairy species than the Pinxter-flower, with a very sticky, glandular corolla tube, and deliciously fragrant blossoms, by no means invariably white. John Burroughs is not the only one who has passed "several patches of swamp honeysuckles, red with blossoms" ("Wake-Robin"). But as this species does not bloom until June and July, when the sun quickly bleaches the delicate flowers, it is true we most frequently find them white, merely tinged with pink. The leaves are well developed before the blossoms appear.

American or Great Rhododendron; Great Laurel; Rose Tree, or Bay

\section{Rhododendron maximum}

Flowers-Rose pink, varying to white, greenish in the throat, spotted with yellow or orange, in broad clusters set like a bouquet among leaves, and developed from scaly, cone-like buds; pedicels sticky-hairy. Calyx 5-parted minute; corolla 5lobed, broadly bell-shaped, 2 in. broad or less; usually 10 stamens, equally spreading; 1 pistil. Stem: Sometimes a tree attaining a height of $40 \mathrm{ft}$., usually 6 to 20 ft., shrubby, woody. Leaves: Evergreen, drooping in winter, leathery, dark green on both sides, lance-oblong, 4 to $10 \mathrm{in}$. long, entire edged, narrowing into stout petioles.

Preferred Habitat-Mountainous woodland, hillsides near streams.

Flowering Season-June-July.

Distribution-Uncommon from Ohio and New England to Nova Scotia; abundant through the Alleghanies to Georgia. 
When this most magnificent of our native shrubs covers whole mountainsides throughout the Alleghany region with bloom, one stands awed in the presence of such overwhelming beauty. Nowhere else does the rhododendron attain such size or luxuriance. There it produces a tall trunk, and towers among the trees; it spreads its branches far and wide until they interlock and form almost impenetrable thickets locally called "hells" where pioneer explorers wandered, lost themselves and perished; it glorifies the loneliest mountain road with superb bouquets of its delicate flowers set among dark, glossy foliage scarcely less attractive. The mountain in bloom is worth travelling a thousand miles to see.

Rhododendrons, azaleas, and laurels fall under a common ban pronounced by bee-keepers. The bees which transfer pollen from blossom to blossom while gathering nectar, manufacture honey said to be poisonous. Cattle know enough to let all this foliage alone. Apparently the ants fear no more evil results from the nectar than the bees themselves; and were it not for the sticky parts nearest the flowers, on which they crawl to meet their death, the blossom's true benefactors would find little refreshment left.

Mountain or American Laurel; Calico Bush; Spoonwood; Calmoun; Broadleaved Kalmia

Kalmia latifolia

Flowers-Buds and new flowers bright rose pink, afterward fading white, and only lined with pink, $1 \mathrm{in}$. across or less, numerous, in terminal clusters. Calyx small, 5-parted, sticky; corolla like a 5-pointed saucer, with 10 projections on outside; 10 arching stamens, an anther lodged in each projection; 1 pistil. Stem: Shrubby, woody, stiffly branched, 2 to $20 \mathrm{ft}$. high. Leaves: Evergreen, entire, oval to elliptic, pointed at both ends, tapering into petioles. Fruit: A round, brown capsule, with the style long remaining on it.

Preferred Habitat-Sandy or rocky woods, especially in hilly or mountainous country.

Flowering Season-May-June.

Distribution-New Brunswick and Ontario, southward to the Gulf of Mexico, and westward to Ohio.

It would be well if Americans, imitating the Japanese in making pilgrimages to scenes of supreme natural beauty, visited the mountains, rocky, woody hillsides, 
ravines, and tree-girt uplands when the laurel is in its glory; when masses of its pink and white blossoms, set among the dark evergreen leaves, flush the landscape like Aurora, and are reflected from the pools of streams and the serene depths of mountain lakes. Peter Kalm, a Swedish pupil of Linnaeus, who travelled here early in the eighteenth century, was more impressed by its beauty than that of any other flower. He introduced the plant to Europe, where it is known as kalmia, and extensively cultivated on fine estates that are thrown open to the public during the flowering season. Even a flower is not without honor, save in its own country. We have only to prepare a border of leaf mould, take up the young plant without injuring the roots or allowing them to dry, hurry them into the ground, and prune back the bush a little, to establish it in our gardens, where it will bloom freely after the second year. Lime in the soil and manure are fatal to it as well as to rhododendrons and azaleas. All they require is a mulch of leaves kept on winter and summer that their fine fibrous roots may never dry out.

All the kalmias resort to a most ingenious device for compelling insect visitors to carry their pollen from blossom to blossom. A newly-opened flower has its stigma erected where the incoming bee must leave on its sticky surface the four minute orange-like grains carried from the anther of another flower on the hairy underside of her body. Now, each anther is tucked away in one of the ten little pockets of the saucer-shaped blossom, and the elastic filaments are strained upward like a bow. After hovering above the nectary, the bee has only to descend toward it, when her leg, touching against one of the hair-triggers of the spring trap, pop! goes the little anther-gun, discharging pollen from its bores as it flies upward. So delicately is the mechanism adjusted, the slightest jar or rough handling releases the anthers; but, on the other hand, should insects be excluded by a net stretched over the plant, the flowers will fall off and wither without firing off their pollen-charged guns. At least, this is true in the great majority of tests. As in the case of hothouse flowers, no fertile seed is set when nets keep away the laurel's benefactors. One has only to touch the hair-trigger with the end of a pin to see how exquisitely delicate is this provision for cross-fertilization.

However much we may be cautioned by the apiculturists against honey made from laurel nectar, the bees themselves ignore all warnings and apparently without evil results-happily for the flowers dependent upon them and their kin. Mr. Frank R. Cheshire, in "Bees and Bee-keeping," the standard English work on the subject, writes: "During the celebrated Retreat of the Ten Thousand, as recorded by Xenophon in his 'Anabasis,' the soldiers regaled themselves upon some honey found near Trebizonde, where were many bee-hives. Intoxication with vomiting was the result. Some were so overcome", he states, "as to be incapable of standing. Not a soldier died, but very many were greatly weakened for several days." 
Tournefort endeavored to ascertain whether this account was corroborated by anything ascertainable in the locality, and had good reason to be satisfied respecting it. He concluded that the honey had been gathered from a shrub growing in the neighborhood of Trebizonde, which is well known there as producing the before-mentioned effects. It is now agreed that the plants were species of rhododendron and azaleas. Lamberti confirms Xenophon's account by stating that similar effects are produced by honey of Colchis, where the same shrubs are common. In 1790, even, fatal cases occurred in America in consequence of eating wild honey, which was traced to Kalmia latifolia by an inquiry instituted under direction of the American government.

Sheep-laurel, Lamb-kill, Wicky, Calf-kill, Sheep-poison, Narrow-leaved Laurel (K. angustifolia), and so on through a list of folk-names testifying chiefly to the plant's wickedness in the pasture, may be especially deadly food for cattle, but it certainly is a feast to the eyes. However much we may admire the small, deep crimson-pink flowers that we find in June and July in moist frelds or swampy ground or on the hillsides, few of us will agree with Thoreau, who claimed that it is "handsomer than the Mountain Laurel." The low shrub may be only six inches high, or it may attain three feet. The narrow evergreen leaves, pale on the underside, have a tendency to form groups of threes, standing upright when newly put forth, but bent downward with the weight of age. A peculiarity of the plant is that clusters of leaves usually terminate the woody stem, for the flowers grow in whorls or in clusters at the side of it below.

\section{Trailing Arbutus; Mayflower; Ground Laurel}

\section{Epigaea repens}

Flowers-Pink, fading to nearly white, very fragrant, about $1 / 2$ in. across when expanded, few or many in clusters at ends of branches. Calyx of 5 dry overlapping sepals; corolla salver-shaped, the slender, hairy tube spreading into 5 equal lobes; 10 stamens; 1 pistil with a column-like style and a 5-lobed stigma. Stem: Spreading over the ground (Epigaea $=$ on the earth); woody, the leafy twigs covered with rusty hairs. Leaves: Alternate, oval, rounded at the base, smooth above, more or less hairy below, evergreen, weather-worn, on short, rusty, hairy petioles.

Preferred Habitat-Light sandy loam in woods, especially under evergreen trees, or in mossy, rocky places.

Flowering Season-March-May. 
Distribution-Newfoundland to Florida, west to Kentucky and the Northwest Territory.

Can words describe the fragrance of the very breath of spring-that delicious commingling of the perfume of arbutus, the odor of pines, and the snow-soaked soil just warming into life? Those who know the flower only as it is sold in the city streets, tied with wet, dirty string into tight bunches, withered and forlorn, can have little idea of the joy of finding the pink, pearly blossoms freshly opened among the withered leaves of oak and chestnut, moss and pine needles in which they nestle close to the cold earth in the leafless, windy northern forest. Even in Florida, where broad patches carpet the woods in February, one misses something of the arbutus's accustomed charm simply because there are no slushy remnants of snowdrifts, no reminders of winter hardships in the vicinity. There can be no glad surprise at finding dainty spring flowers in a land of perpetual summer. Little wonder that the Pilgrim Fathers, after the first awful winter on the "stern New England coast," loved this early messenger of hope and gladness above the frozen ground at Plymouth. In an introductory note to his poem "The Mayflowers," Whittier states that the name was familiar in England, as the application of it to the historic vessel shows; but it was applied by the English, and still is, to the hawthorn. Its use in New England in connection with the Trailing Arbutus dates from a very early day, some claiming that the first Pilgrims so used it in affectionate memory of the vessel and its English flower association.

"Sad Mayflower! watched by winter stars,

And nursed by winter gales,

With petals of the sleeted spars,

And leaves of frozen sails!

\section{"But warmer suns ere long shall bring \\ To life the frozen sod, \\ And through dead leaves of hope shall spring \\ Afresh the flowers of God!"}

There is little use trying to coax this shyest of sylvan flowers into our gardens where other members of its family, rhododendrons, laurels, and azaleas make themselves delightfully at home. It is wild as a hawk, an untamable creature that slowly pines to death when brought into contact with civilization. Greedy street venders, who ruthlessly tear up the plant by the yard, and others without even the excuse of eking out a paltry income by its sale, have already exterminated it within a wide radius of our Eastern cities. How curious that the majority of people show their appreciation of a flower's beauty only by selfishly, ignorantly picking every specimen they can find! 
Creeping Wintergreen; Checker-berry; Partridge-berry; Mountain Tea; Ground Tea, Deer, Box, or Spice Berry

\section{Gaultheria procumbens}

Flowers - White, small, usually solitary, nodding from a leaf axil. Corolla rounded bell-shape, 5-toothed; calyx 5-parted, persistent; 10 included stamens, their anther-sacs opening by a pore at the top. Stem: Creeping above or below ground, its branches 2 to $6 \mathrm{in}$. high. Leaves: Mostly clustered at top of branches; alternate, glossy, leathery, evergreen, much darker above than underneath, oval to oblong, very finely saw-edged; the entire plant aromatic. Fruit: Bright red, mealy, spicy, berry-like; ripe in October.

Preferred Habitat-Cool woods, especially under evergreens.

Flowering Season-June-September.

Distribution-Newfoundland to Georgia, westward to Michigan and Manitoba.

"Where cornels arch their cool, dark boughs o'er beds of wintergreen," wrote Bryant; yet it is safe to say that nine colonies out of ten of this hardy little plant are under evergreens, not dogwood trees. Poets make us feel the spirit of Nature in a wonderful way, but-look out for their facts!

Omnivorous children who are addicted to birch-chewing prefer these tender yellow-green leaves tinged with red, when newly put forth in June-"Youngsters" rural New Englanders call them then. In some sections a kind of tea is steeped from the leaves, which also furnish the old-fashioned embrocation, wintergreen oil. Late in the year the glossy bronze carpet of old leaves dotted over with vivid red "berries" invites much trampling by hungry birds and beasts, especially deer and bears, not to mention well-fed humans. Coveys of Bob Whites and packs of grouse will plunge beneath the snow for fare so delicious as this spicy, mealy fruit that hangs on the plant till spring, of course for the benefit of just such colonizing agents as they. Quite a different species, belonging to another family, bears the true partridge-berry, albeit the wintergreen shares with it a number of popular names. In a strict sense neither of these plants produces a berry; for the fruit of the true Partridge Vine (Mitchella repens) is a double drupe, or stone bearer, each half containing four hard, seed-like nutlets; while the wintergreen's so-called berry is merely the calyx grown thick, fleshy, and gayly colored-only a coating for the five-celled ovary that contains the minute seeds. Little baskets of wintergreen berries bring none too high prices in the fancy fruit and grocery shops when we calculate how many charming plants such unnatural use of them sacrifices. 


\section{PRIMROSE FAMILY (Primulaceae)}

Four-leaved or Whorled Loosestrife; Crosswort

Lysimachia quadrifolia

Flowers-Yellow, streaked with, dark red, $1 / 2$ in. across or less; each on a threadlike, spreading footstem from a leaf axil. Calyx, 5 to 7 parted; corolla of 5 to 7 spreading lobes, and as many stamens inserted on the throat; 1 pistil. Stem: Slender, erect, 1 to $3 \mathrm{ft}$. tall, leafy. Leaves: In whorls of 4 (rarely in 3's to 7's), lance-shaped or oblong, entire, black dotted.

Preferred Habitat-Open woodland, thickets, roadsides; moist, sandy soil.

Flowering Season-June-August.

Distribution-Georgia and lllinois, north to New Brunswick.

Medieval herbalists usually recorded anything that "Plinie saieth" with profoundest respect; not always so, quaint old Parkinson. Speaking of the common (vulgaris) Wild Loosestrife of Europe, a rather stout, downy species with terminal clusters of good-sized, yellow flowers, that was once cultivated in our Eastern states, and has sparingly escaped from gardens, he thus refers to the reputation given it by the Roman naturalist: "It is believed to take away strife, or debate between ye beasts, not onely those that are yoked together, but even those that are wild also, by making them tame and quiet ... if it be either put about their yokes or their necks," significantly adding, "which how true, I leave to them shall try 
and find it soe." Our slender, symmetrical, common loosestrife, with its whorls of leaves and little star-shaped blossoms on thread-like pedicels at regular intervals up the stem, is not even distantly related to the wonderful Purple Loosestrife.

Another common, lower-growing species, the Bulb-bearing Loosestrife (L. terrestris), blooms from July to September and shows a decided preference for swamps and ditches throughout a range which extends from Manitoba and Arkansas to the Atlantic Ocean.

Star-flower; Chickweed Wintergreen; Star Anemone

Trientalis americana Flowers-White, solitary, or a few rising on slender, wiry footstalks above a whorl of leaves. Calyx of 5 to 9 (usually 7) narrow sepals. Corolla wheel-shaped, 1/2 in. across or less, deeply cut into (usually) 7 tapering, spreading, petal-like segments. Stem: A long horizontal rootstock, sending up smooth stem-like branches 3 to $9 \mathrm{in}$. high, usually with a scale or two below. (Trientalis = one third of a foot, the usual height of a plant.) Leaves: 5 to 10 , in a whorl at summit; thin, tapering at both ends, of unequal size, 1-1/2 to $4 \mathrm{in}$. long.

Preferred Habitat-Moist shade of woods and thickets.

Flowering Season-May-June.

Distribution-From Virginia and Illinois far north.

Is any other blossom poised quite so airily above its whorl of leaves as the delicate, frosty-white little star-flower? It is none of the anemone kin, of course, in spite of one of its misleading folk-names; but only the wind-flower has a similar lightness and grace.

Scarlet Pimpernel; Poor Man's or Shepherd's Weatherglass; Red Chickweed; Burnet Rose; Shepherd's Clock

Anagallis arvensis

Flower-Variable, scarlet, deep salmon, copper red, flesh colored, or rarely white; usually darker in the centre; about $1 / 4$ in. across; wheel-shaped; 5-parted; solitary, on thread-like peduncles from the leaf axils. Stem: Delicate; 4-sided, 4 to $12 \mathrm{in}$. long, much branched, the sprays weak and long. Leaves: Oval, opposite, sessile, black dotted beneath. 
Preferred Habitat—Waste places, dry fields and roadsides, sandy soil.

Flowering Season-May-August.

Distribution-Newfoundland to Florida, westward to Minnesota and Mexico.

Tiny pimpernel flowers of a reddish copper or terra cotta color have only to be seen to be named, for no other blossoms on our continent are of the same peculiar shade.

Before a storm, when the sun goes under a cloud, or on a dull day, each little weather prophet closes. A score of pretty folk-names given it in every land it adopts testifies to its sensitiveness as a barometer. Under bright skies the flower may be said to open out flat at about nine in the morning and to begin to close at three in the afternoon.

Shooting Star; American Cowslip; Pride of Ohio

\section{Dodecatheon Meadia}

Flowers-Purplish pink or yellowish white, the cone tipped with yellow; few or numerous, hanging on slender, recurved pedicels in an umbel at top of a simple scape 6 in. to $2 \mathrm{ft}$. high. Calyx deeply 5-parted; corolla of 5 narrow lobes bent backward and upward; the tube very short, thickened at throat, and marked with dark reddish purple dots; 5 stamens united into a protruding cone; 1 pistil, protruding beyond them. Leaves: Oblong or spatulate, 3 to 12 in. long, narrowed into petioles, all from fibrous roots. Fruit: A 5-valved capsule on erect pedicels.

Preferred Habitat—Prairies, open woods, moist cliffs.

Flowering Season-April-May.

Distribution-Pennsylvania southward and westward, and from Texas to Manitoba.

Ages ago Theophrastus called an entirely different plant by this same scientific name, derived from dodeka = twelve, and theos = gods; and although our plant is native of a land unknown to the ancients, the fanciful Linnaeus imagined he saw in the flowers of its umbel a little congress of their divinities seated around a miniature Olympus! Who has said science kills imagination? These handsome, interesting flowers, so familiar in the Middle West and Southwest, especially, 
somewhat resemble the cyclamen in oddity of form. Indeed, these prairie wild flowers are not unknown in florists' shops in Eastern cities.

Few bee workers are abroad at the shooting star's season. The female bumblebees, which, by striking the protruding stigma before they jar out any pollen, cross-fertilize it, are the flower's chief benefactors, but one often sees the little yellow puddle butterfly about it. Very different from the bright yellow cowslip of Europe is our odd, misnamed blossom. 


\section{GENTIAN FAMILY (Gentianaceae)}

Bitter-bloom; Rose Pink; Square-stemmed Sabbatia; Rosy Centaury

Sabbatia angularis

Flowers-Clear rose pink, with greenish star in centre, rarely white, fragrant, 1$1 / 2$ in. broad or less, usually solitary on long peduncles at ends of branches. Calyx lobes very narrow; corolla of 5 rounded segments; stamens 5; style 2-cleft. Stem: Sharply 4-angled, 2 to $3 \mathrm{ft}$. high, with opposite branches, leafy. Leaves: Opposite, 5-nerved, oval tapering at tip, and clasping stem by broad base.

Preferred Habitat-Rich soil, meadows, thickets.

Flowering Season-July-August.

Distribution-New York to Florida, westward to Ontario, Michigan, and Indian Territory.

During the drought of midsummer the lovely Rose Pink blooms inland with cheerful readiness to adapt itself to harder conditions than most of its moistureloving kin will tolerate; but it may be noticed that although we may often-times find it growing in dry soil, it never spreads in such luxuriant clusters as when the roots are struck beside meadow runnels and ditches. Probably the plant would be commoner than it is about populous Eastern districts were it not so much sought by herb-gatherers for use as a tonic medicine. 
It was the Centaurea, represented here by the blue Ragged Sailor of gardens, and not our Centaury, a distinctly American group of plants, which, Ovid tells us, cured a wound in the foot of the Centaur Chiron, made by an arrow hurled by Hercules.

Three exquisite members of the Sabbatia tribe keep close to the Atlantic Coast in salt meadows and marshes, along the borders of brackish rivers, and very rarely in the sand at the edges of fresh-water ponds a little way inland. From Maine to Florida they range, and less frequently are met along the shores of the Gulf of Mexico so far as Louisiana. How bright and dainty they are! Whole meadows are radiant with their blushing loveliness. Probably if they consented to live far away from the sea, they would lose some of the deep, clear pink from out their lovely petals, since all flowers show a tendency to brighten their colors as they approach the coast. In England some of the same wild flowers we have here are far deeperhued, owing, no doubt, to the fact that they live on a sea-girt, moisture-laden island, and also that the sun never scorches and blanches at the far north as it does in the United States.

The Sea or Marsh Pink or Rose of Plymouth (S. stellaris), whose graceful alternate branching stem attains a height of two feet only under most favorable conditions, from July to September opens a succession of pink flowers that often fade to white. The yellow eye is bordered with carmine. They measure about one inch across, and are usually solitary at the ends of branches, or else sway on slender peduncles from the axils. The upper leaves are narrow and bract-like; those lower down gradually widen as they approach the root.

\section{Fringed Gentian}

\section{Gentiana crinita}

Flowers - Deep, bright blue, rarely white, several or many, about 2 in. high, stiffly erect, and solitary at ends of very long footstalk. Calyx of 4 unequal, acutely pointed lobes. Corolla funnel form, its four lobes spreading, rounded, fringed around ends, but scarcely on sides. Four stamens inserted on corolla tube; 1 pistil with 2 stigmas. Stem: 1 to $3 \mathrm{ft}$. high, usually branched, leafy. Leaves: Opposite, upper ones acute at tip, broadening to heart-shaped base, seated on stem. Fruit: A spindle-shaped, 2-valved capsule, containing numerous scaly, hairy seeds.

Preferred Habitat-Low, moist meadows and woods. 
Flowering Season-September-November.

Distribution-Quebec, southward to Georgia, and westward beyond the Mississippi.

"Thou waitest late, and com'st alone

When woods are bare and birds have flown,

And frosts and shortening days portend

The aged year is near his end.

"Then doth thy sweet and quiet eye

Look through its fringes to the sky,

Blue_blue - as if that sky let fall

A flower from its cerulean wall."

When we come upon a bed of gentians on some sparkling October day, we can but repeat Bryant's thoughts and express them prosaically who attempt description. In dark weather this sunshine lover remains shut, to protect its nectar and pollen from possible showers. An elusive plant is this gentian, which by no means always reappears in the same places year after year, for it is an annual whose seeds alone perpetuate it. Seating themselves on the winds when autumn gales shake them from out the home wall, these little hairy scales ride afar, and those that are so fortunate as to strike into soft, moist soil at the end of the journey, germinate. Because this flower is so rarely beautiful that few can resist the temptation of picking it, it is becoming sadly rare near large settlements.

Fifteen species of gentian have been gathered during a half-hour walk in Switzerland, where the pastures are spread with sheets of blue. Indeed, one can litthe realize the beauty of these heavenly flowers who has not seen them among the Alps.

A deep, intense blue is the Closed, Blind, or Bottle Gentian (G. Andrewsii), more truly the color of the "male bluebird's back," to which Thoreau likened the paler Fringed Gentian. Rarely some degenerate plant bears white flowers. As it is a perennial, we are likely to find it in its old haunts year after year; nevertheless its winged seeds sail far abroad to seek pastures new. This gentian also shows a preference for moist soil. Gray thought that it expanded slightly, and for a short time only in sunshine, but added that, although it is proterandrous, i.e., it matures and sheds its pollen before its stigma is susceptible to any, he believed it finally fertilized itself by the lobes of the stigma curling backward until they touched the 
anthers. But Gray was doubtless mistaken. Several authorities have recently proved that the flower is adapted to bumblebees. It offers them the last feast of the season, for although it comes into bloom in August southward, farther northward - and it extends from Quebec to the Northwest Territory-it lasts through October. 


\section{DOGBANE FAMILY (Apocynaceae)}

Spreading Dogbane; Fly-trap Dogbane; Honey-bloom; Bitter-root

Apocynum androsaemifolium

Flowers-Delicate pink, veined with a deeper shade, fragrant, bell-shaped, about $1 / 3$ in. across, borne in loose terminal cymes. Calyx 5-parted; corolla of 5 spreading, recurved lobes united into a tube; within the tube 5 tiny, triangular appendages alternate with stamens; the arrow-shaped anthers united around the stigma and slightly adhering to it. Stem: 1 to $4 \mathrm{ft}$. high, with forking, spreading, leafy branches. Leaves: Opposite, entire-edged, broadly oval, narrow at base, paler, and more or less hairy below. Fruit: Two pods about 4 in. long.

Preferred Habitat-Fields, thickets, beside roads, lanes, and walls.

Flowering Season-June-July.

Distribution-Northern part of British Possessions south to Georgia, westward to Nebraska.

Everywhere at the North we come across this interesting, rather shrubby plant, with its pretty but inconspicuous little rose-veined bells suggesting pink lilies-ofthe-valley. Now that we have learned to read the faces of flowers, as it were, we instantly suspect by the color, fragrance, pathfinders, and structure that these are artful wilers, intent on gaining ends of their own through their insect admirers. What are they up to? 
Let us watch. Bees, flies, moths, and butterflies, especially the latter, hover near. Alighting, the butterfly visitor unrolls his long tongue and inserts it where the five pink veins tell him to, for five nectar-bearing glands stand in a ring around the base of the pistil. Now, as he withdraws his slender tongue through one of the Vshaped cavities that make a circle of traps, he may count himself lucky to escape with no heavier toll imposed than pollen cemented to it. This granular dust he is required to rub off against the stigma of the next flower entered. Some bees, too, have been taken with the dogbane's pollen cemented to their tongues. But suppose a fly call upon this innocent-looking blossom? His short tongue, as well as the butterfly's, is guided into one of the V-shaped cavities after he has sipped; but, getting wedged between the trap's horny teeth, the poor little victim is held a prisoner there until he slowly dies of starvation in sight of plenty. This is the penalty he must pay for trespassing on the butterfly's preserves! The dogbane, which is perfectly adapted to the butterfly, and dependent upon it for help in producing fertile seed, ruthlessly destroys all poachers that are not big or strong enough to jerk away from its vise-like grasp. One often sees small flies and even moths dead and dangling by the tongue from the wicked little charmers. If the flower assimilated their dead bodies as the pitcher plant, for example, does those of its victims, the fly's fate would seem less cruel. To be killed by slow torture and dangled like a scarecrow simply for pilfering a drop of nectar is surely an execution of justice medieval in its severity. 


\section{MILKWEED FAMILY (Aselepiadaceae)}

Common Milkweed or Silkweed

Asclepias syriaca (A. cornuti)

Flowers-Dull, pale greenish purple pink, or brownish pink, borne on pedicels, in many flowered, broad umbels. Calyx inferior, 5-parted; corolla deeply 5-cleft, the segments turned backward. Above them an erect, 5-parted crown, each part called a hood, containing a nectary, and with a tooth on either side, and an incurved horn projecting from within. Behind the crown the short, stout stamens, united by their filaments in a tube, are inserted on the corolla. Broad anthers united around a thick column of pistils terminating hi a large, sticky, 5-angled disk. The anther sacs tipped with a winged membrane; a waxy, pear-shaped pollenmass in each sac connected with the stigma in pairs or fours by a dark gland, and suspended by a stalk like a pair of saddle-bags. Stem: Stout, leafy, usually unbranched, 3 to $5 \mathrm{ft}$. high, juice milky. Leaves: Opposite, oblong, entire-edged smooth above, hairy below, 4 to 9 in. long. Fruit: 2 thick, warty pods, usually only one filled with compressed seeds attached to tufts of silky, white, fluffy hairs.

Preferred Habitat-Fields and waste places, roadsides.

Flowering Season-June-September.

Distribution-New Brunswick, far westward and southward to North Carolina and Kansas. 
After the orchids, no flowers show greater executive ability, none have adopted more ingenious methods of compelling insects to work for them than the milkweeds. Wonderfully have they perfected their mechanism in every part until no member of the family even attempts to fertilize itself; hence their triumphal, vigorous march around the earth, the tribe numbering more than nineteen hundred species located chiefly in those tropical and warm temperate regions that teem with the insects whose cooperation they seek.

Commonest of all with us is this rank weed, which possesses the dignity of a rubber plant. Much more attractive to human eyes, at least, than the dull, pale, brownish-pink umbels of flowers are its exquisite silky seed-tufts. But not so with insects. Knowing that the slightly fragrant blossoms are rich in nectar, bees, wasps, flies, beetles, and butterflies come to feast. Now, the visitor finding his alighting place slippery, his feet claw about in all directions to secure a hold, just as it was planned they should; for in his struggles some of his feet must get caught in the fine little clefts at the base of the flower. His efforts to extricate his foot only draw it into a slot at the end of which lies a little dark-brown body. In a newly-opened flower five of these little bodies may be seen between the horns of the crown, at equal distances around it. This tiny brown excrescence is hard and horny, with a notch in its face. It is continuous with and forms the end of the slot in which the visitor's foot is caught. Into this he must draw his foot or claw, and finding it rather tightly held, must give a vigorous jerk to get it free. Attached to either side of the little horny piece is a flattened yellow pollen-mass, and so away he flies with a pair of these pollinia, that look like tiny saddle-bags, dangling from his feet. One might think that such rough handling as many insects must submit to from flowers would discourage them from making any more visits; but the desire for food is a mighty passion. While the insect is flying off to another blossom, the stalk to which the saddle-bags are attached twists until it brings them together, that, when his feet get caught in other slots, they may be in the position to get broken off in his struggles for freedom precisely where they will fertilize the stigmatic chambers. Now the visitor flies away with the stalks alone sticking to his claws. Bumblebees and hive-bees have been caught with a dozen pollen-masses dangling from a single foot. Outrageous imposition!

Better than any written description of the milkweed blossom's mechanism is a simple experiment. If you have neither time nor patience to sit in the hot sun, magnifying-glass in hand, and watch for an unwary insect to get caught, take an ordinary house-fly, and hold it by the wings so that it may claw at one of the newly-opened flowers from which no pollinia have been removed. It tries frantically to hold on, and with a little direction it may be led to catch its claws in the slots of the flower. Now pull it gently away, and you will find a pair of saddle-bags 
slung over his foot by a slender curved stalk. If you are rarely skilful, you may induce your fly to withdraw the pollinia from all five slots on as many of his feet. And they are not to be thrown or scraped off, let the fly try as hard as he pleases. You may now invite the fly to take a walk on another flower in which he will probably leave one or more pollinia in its stigmatic cavities.

Doctor Kerner thought the milky juice in milkweed plants, especially abundant in the uppermost leaves and stems, serves to protect the flowers from useless crawling pilferers. He once started a number of ants to climb up a milky stalk. When they neared the summit, he noticed that at each movement the terminal hooks of their feet cut through the tender epiderm, and from the little clefts the milky juice began to flow, bedraggling their feet and the hind part of then-bodies. "The ants were much impeded in their movements," he writes, "and in order to rid themselves of the annoyance, drew their feet through their mouths... Their movements, however, which accompanied these efforts, simply resulted in making fresh fissures and fresh discharges of milky juice, so that the position of the ants became each moment worse and worse. Many escaped by getting to the edge of a leaf and dropping to the ground. Others tried this method of escape too late, for the air soon hardened the milky juice into a tough brown substance, and after this, all the strugglings of the ants to free themselves from the viscid matter were in vain." Nature's methods of preserving a flower's nectar for the insects that are especially adapted to fertilize it, and of punishing all useless intruders, often shock us; yet justice is ever stern, ever kind in the largest sense.

If the asclepias really do kill some insects with their juice, others doubtless owe their lives to it. Among the "protected" insects are the milkweed butterflies and their caterpillars, which are provided with secretions that are distasteful to birds and predaceous insects. "These acrid secretions are probably due to the character of the plants upon which the caterpillars feed," says Doctor Holland, in his beautiful and invaluable "Butterfly Book." "Enjoying on this account immunity from attack, they have all, in the process of time, been mimicked by species in other genera which have not the same immunity." "One cannot stay long around a patch of milkweeds without seeing the monarch butterfly (Anosia plexippus), that splendid, bright, reddish-brown winged fellow, the borders and veins broadly black, with two rows of white spots on the outer borders and two rows of pale spors across the tip of the fore wings. There is a black scent-pouch on the hind wings. The caterpillar, which is bright yellow or greenish yellow, banded with shining black, is furnished with black fleshy 'horns' fore and aft."

Like the dandelion, thistle, and other triumphant strugglers for survival, the milkweed sends its offspring adrift on the winds to found fresh colonies afar. 
Children delight in making pompons for their hats by removing the silky seedtufts from pods before they burst, and winding them, one by one, on slender stems with fine thread. Hung in the sunshine, how charmingly fluffy and soft they dry!

Among the comparatively few butterfly flowers-although, of course, other insects not adapted to them are visitors-is the Purple Milkweed (A. purpurasceus), whose deep magenta umbels are so conspicuous through the summer months. Humming birds occasionally seek it, too. From eastern Massachusetts to Virginia, and westward to the Mississippi, or beyond, it is to be found in dry fields, woods, and thickets.

Butterfly-weed; Pleurisy-root; Orange-root; Orange Milkweed

Asclepias tuberosa

Flowers-Bright reddish orange, in many-flowered, terminal clusters, each flower similar in structure to the common milkweed (see above). Stem: Erect, 1 to $2 \mathrm{ft}$. tall, hairy, leafy, milky juice scanty. Leaves: Usually all alternate, lance-shaped, seated on stem. Fruit: A pair of erect, hoary pods, 2 to 5 in. long, 1 at least containing silky plumed seeds.

Preferred Habitat—Dry or sandy fields, hills, roadsides.

Flowering Season-June-September.

Distribution-Maine and Ontario to Arizona, south to the Gulf of Mexico.

Intensely brilliant clusters of this the most ornamental of all native milkweeds set dry fields ablaze with color. Above them butterflies hover, float, alight, sip, and sail away - the great dark, velvety, pipe-vine swallow-tail (Papilio philenor), its green-shaded hind wings marked with little white half moons; the yellow and brown, common, Eastern swallow-tail (P. asterias), that we saw about the wild parsnip and other members of the carrot family; the exquisite, large, spice-bush swallow-tail, whose bugaboo caterpillar startled us when we unrolled a leaf of its favorite food supply; the small, common, white cabbage butterfly (Pieris protodice); the even more common little sulphur butterflies, inseparable from clover fields and mud puddles; the painted lady that follows thistles around the globe; the regal fritillary (Argynnis idalia), its black and fulvous wings marked with sil- 
ver crescents, a gorgeous creature developed from the black and orange caterpillar that prowls at night among violet plants; the great spangled fritillary of similar habit; the bright fulvous and black pearl crescent butterfly (Phyciodes tharos), its small wings usually seen hovering about the asters; the little grayish-brown, coral hairstreak (Thecla titus), and the bronze copper (Chrysophanus thoe), whose caterpillar feeds on sorrel (Rumex); the delicate, tailed blue butterfly (Lycena comyntas,) with a wing expansion of only an inch from tip to tip; all these visitors duplicated again and again-these and several others that either escaped the net before they were named, or could not be run down, were seen one bright midsummer day along a Long Island roadside bordered with butterfly weed. Most abundant of all was still another species, the splendid monarch (Anosia plexippus), the most familiar representative of the tribe of milkweed butterflies. It is said the Indians used the tuberous root of this plant for various maladies, although they could scarcely have known that because of the alleged healing properties of the genus Linnaeus dedicated it to Aesculapius, of whose name Asklepios is the Greek form. 


\section{CONVOLVULUS FAMILY (Convolvulaceae)}

Hedge or Great Bindweed; Wild Morning-glory; Rutland Beauty; Bell-bind; Lady's Nightcap

\section{Convolvulus sepium}

Flowers-Light pink, with white stripes or all white, bell-shaped, about 2 in. long, twisted in the bud, solitary, on long peduncles from leaf axils. Calyx of 5 sepals, concealed by 2 large bracts at base. Corolla 5-lobed, the 5 included stamens inserted on its tube; style with 2 oblong stigmas. Stem: Smooth or hairy, 3 to $10 \mathrm{ft}$. long, twining or trailing over ground. Leaves: Triangular or arrowshaped, 2 to $5 \mathrm{in}$. long, on slender petioles.

Preferred Habitat-Wayside hedges, thickets, fields, walls.

Flowering Season-June-September.

Distribution-Nova Scotia to North Carolina, westward to Nebraska. Europe and Asia.

No one need be told that the pretty, bell-shaped pink and white flower on the vigorous vine clambering over stone walls and winding about the shrubbery of wayside thickets in a suffocating embrace is akin to the morning-glory of the garden trellis (C. Major). An exceedingly rapid climber, the twining stem often describes a complete circle in two hours, turning against the sun, or just contrary to the hands of a watch. Late in the season, when an abundance of seed has been set, the 
flower can well afford to keep open longer hours, also in rainy weather; but early in the summer, at least, it must attend to business only while the sun shines and its benefactors are flying. Usually it closes at sundown. On moonlight nights, however, the hospitable blossom keeps open for the benefit of certain moths.

From July until hard frost look for that exquisite little beetle, Cassida aurichalcea, like a drop of molten gold, clinging beneath the bindweed's leaves. The small perforations reveal his hiding places. "But you must be quick if you would capture him," says William Hamilton Gibson, "for he is off in a spangling streak of glitter. Nor is this golden sheen all the resource of the little insect; for in the space of a few seconds, as you hold him in your hand, he has become a milky, iridescent opal, and now mother-of-pearl, and finally crawls before you in a coat of dull orange." A dead beetle loses all this wonderful lustre. Even on the morning-glory in our gardens we may sometimes find these jewelled mites, or their fork-tailed, black larvae, or the tiny chrysalids suspended by their tails, although it is the wild bindweed that is ever their favorite abiding place.

Gronovius' or Common Dodder; Strangle-weed; Love Vine; hingel's Hair

\section{Cuscuta Gronovii}

Flowers-Dull, white minute, numerous, in dense clusters. Calyx inferior, greenish white, 5-parted; corolla bell-shaped, the 5 lobes spreading, 5 fringed scales within; 5 stamens, each inserted on corolla throat above a scale; 2 slender styles. Stem: Bright orange yellow, thread-like, twining high, leafless.

Preferred Habitat-Moist soil, meadows, ditches, beside streams.

Flowering Season-July-September.

Distribution-Nova Scotia and Manitoba, south to the Gulf states.

Like tangled yellow yarn wound spirally about the herbage and shrubbery in moist thickets, the dodder grows, its beautiful bright threads plentifully studded with small flowers tightly bunched. Try to loosen its hold on the support it is climbing up, and the secret of its guilt is out at once; for no honest vine is this, but a parasite, a degenerate of the lowest type, with numerous sharp suckers (haustoria) penetrating the bark of its victim, and spreading in the softer tissues beneath to steal all their nourishment. So firmly are these suckers attached, that the golden thread-like stem will break before they can be torn from their hold. 
Not a leaf now remains on the vine to tell of virtue in its remote ancestors; the absence of green matter (chlorophyll) restifies to dishonest methods of gaining a living (see Indian Pipe), not even a root is left after the seedling is old enough to twine about its hard-working, respectable neighbors. Starting out in life with apparently the best intentions, suddenly the tender young twiner develops an appetite for strong drink and murder combined, such as would terrify any budding criminat in Five Points or Seven Dials! No sooner has it laid hold of its victim and tapped it, than the now useless root and lower portion wither away leaving the dodder in mid-air, without any connection with the soil below, but abundantly nourished with juices already stored up, and even assimilated, at its host's expense. By rapidly lengthening the cells on the outer side of its stem more than on the inner side, the former becomes convex, the latter concave; that is to say, a section of spiral is formed by the new shoot, which, twining upward, devitalizes its benefactor as it goes. Abundant, globular seed-vessels, which develop rapidly while the blossoming continues unabated, soon sink into the soft soil to begin their piratical careers close beside the criminals which bore them; or better still, from their point of view, float downstream to found new colonies afar. When the beautiful jewel-iveed - a conspicuous sufferer-is hung about with dodder, one must be grateful for at least such symphony of yellows. 


\section{POLEMONIUM FAMILY (Polemoniaceae)}

Ground or Moss Pink

Phlox subulata

Flowers-Very numerous, small, deep purplish pink, lavender or rose, varying to white, with a darker eye, growing in simple cymes, or solitary in a Western variety. Calyx with 5 slender teeth; corolla salver-form with 5 spreading lobes; 5 stamens inserted on corolla tube; style 3-lobed. Stems: Rarely exceeding 6 in. in height, tufted like mats, much branched, plentifully set with awl-shaped, evergreen leaves barely $1 / 2 \mathrm{in}$. long, growing in tufts at joints of stem.

Preferred Habitat-Rocky ground, hillsides.

Flowering Season-April-June.

Distribution-Southern New York to Florida, westward to Michigan and Kentucky.

A charming little plant, growing in dense evergreen mats with which Nature carpets dry, sandy, and rocky hillsides, is often completely hidden beneath its wealth of flowers. Far beyond its natural range, as well as within it, the Moss Pink glows in gardens, cemeteries, and parks, wherever there are rocks to conceal or sterile wastes to beautify. Very slight encouragement induces it to run wild. There are great rocks in Central Park, New York, worth travelling miles to see in early May, when their stern faces are flushed and smiling with these blossoms. 


\section{BORAGE FAMILY (Boraginaceae)}

Forget-me-not; Mouse-ear; Scorpion Grass; Snake Grass; Love Me

Myosotis scorpioides (M. palustris)

Flowers-Pure blue, pinkish, or white, with yellow eye; flat, 5-lobed, borne in many-flowered, long, often 1-sided racemes. Calyx 5-cleft; the lobes narrow, spreading, erect, and open in fruit; 5 stamens inserted on corolla tube; style thread-like; ovary 4-celled. Stem: Low, branching, leafy, slender, hairy, partially reclining. Leaves: (Myosotis = mouse-ear) oblong, alternate, seated on stem; hairy. Fruit: Nutlets, angled and keeled on inner side.

Preferred Habitat - Escaped from gardens to brooksides, marshes, and low meadows.

Flowering Season-May-July.

Distribution-Native of Europe and Asia, now rapidly spreading from Nova Scotia southward to New Jersey, Pennsylvania, and beyond.

How rare a color blue must have been originally among our flora is evident from the majority of blue and purple flowers that, although now abundant here and so perfectly at home, are really quite recent immigrants from Europe and Asia. But our dryer, hotter climate never brings to the perfection attained in England 
That grow for happy lovers."

Tennyson thus ignores the melancholy association of the flower in the popular legend which tells how a lover, when trying to gather some of these blossoms for his sweetheart, fell into a deep pool, and threw a bunch on the bank, calling out, as he sank forever from her sight, "Forget me not." Another dismal myth sends its hero forth seeking hidden treasure caves in a mountain, under the guidance of a fairy. He fills his pockets with gold, but not heeding the fairy's warning to "forget not the best" - i.e., the myosotis- he is crushed by the closing together of the mountain. Happiest of all is the folk-tale of the Persians, as told by their poet Shiraz: "It was in the golden morning of the early world, when an angel sat weeping outside the closed gates of Paradise. He had fallen from his high estate through loving a daughter of earth, nor was he permitted to enter again until she whom he loved had planted the flowers of the forget-me-not in every corner of the world. He returned to earth and assisted her, and together they went hand in hand. When their task was ended, they entered Paradise together, for the fair woman, without tasting the bitterness of death, became immortal like the angel whose love her beauty had won when she sat by the river twiring forget-me-nots in her hair."

It was the golden ring around the forget-me-not's centre that first led Sprengel to believe the conspicuous markings at the entrance of many flowers served as pathfinders to insects. This golden circle also shelters the nectar from rain, and indicates to the fly or bee just where it must probe between stigma and anthers to touch them with opposite sides of its tongue. Since it may probe from any point of the circle, it is quite likely that the side of the tongue that touched a pollenladen anther in one flower will touch the stigma in the next one visited, and so cross-fertilize it. But forget-me-nots are not wholly dependent on insects. When these fail, a fully mature flower is still able to set fertile seed by shedding its own pollen directly on the stigma.

Viper's Bugloss; Blue-weed; Viper's Herb or Grass; Snake-flower; Blue Thistle; Blue Devil

\section{Echium vulgare}

Flowers-Bright blue, afterward reddish purple, pink in the bud, numerous, clustered on short, 1-sided curved spikes rolled up at first, and straightening out as flowers expand. Calyx deeply 5 -cleft; corolla 1 in. long or less, funnel form, the 5 lobes unequal, acute; 5 stamens inserted on corolla tube, the filaments spreading below, and united above into slender appendage, the anthers forming a cone; 1 
pistil with 2 stigmas. Stem: 1 to 2 1/2 ft. high; bristly-hairy, erect, spotted. Leaves: Hairy, rough, oblong to lance-shaped, alternate, seated on stem, except at base of plant.

Preferred Habitat—Dry fields, waste places, roadsides

Flowering Season-June-July.

Distribution-New Brunswick to Virginia, westward to Nebraska; Europe and Asia.

Years ago, when simple folk believed God had marked plants with some sign to indicate the special use for which each was intended, they regarded the spotted stem of the bugloss, and its seeds shaped like a serpent's head, as certain indications that the herb would cure snake bites. Indeed, the genus takes its name from Echis, the Greek viper. 


\section{VERVAIN FAMILY (Verbenaceae)}

Blue Vervain; Wild Hyssop; Simpler's Joy

Verbena hastata

Flowers--Very small, purplish blue, in numerous slender, erect, compact spikes. Calyx 5-toothed; corolla tubular, unequally 5-lobed; 2 pairs of stamens; 1 pistil. Stem: 3 to $7 \mathrm{ft}$. high, rough, branched above, leafy, 4-sided. Leaves: Opposite, stemmed, lance-shaped, saw-edged rough, lower ones lobed at base.

Preferred Habitat-Moist meadows, roadsides, waste places.

Flowering Season-June-September.

Distribution-United States and Canada in almost every part.

Seeds below, a circle of insignificant purple-blue flowers in the centre, and buds at the top of the vervain's slender spires do not produce a striking effect, yet this common plant certainly does not lack beauty. John Burroughs, ever ready to say a kindly, appreciative word for any weed, speaks of its drooping, knotted threads, that "make a pretty etching upon the winter snow." Bees, the vervain's benefactors, are usually seen clinging to the blooming spikes, and apparently asleep on them. Borrowing the name of Simpler's Joy from its European sister, the flower has also appropriated much of the tradition and folk-lore centred about that plant which herb-gatherers, or simplers, truly delighted to see, since none was once more salable. 
Ages before Christians ascribed healing virtues to the vervain-found growing on Mount Calvary, and therefore possessing every sort of miraculous power, according to the logic of simple peasant folk-the Druids had counted it among their sacred plants. "When the dog-star arose from unsunned spots" the priests gathered it. Did not Shakespeare's witches learn some of their uncanny rites from these reverend men of old? One is impressed with the striking similarity of many customs recorded of both. Two of the most frequently used ingredients in witches cauldrons were the vervain and the rue. "The former probably derived its notoriety from the fact of its being sacred to Thor, an honor which marked it out, like other lightning plants, as peculiarly adapted for occult uses," says Mr. Thiselton Dyer in his "Folk-lore of Plants." "Although vervain, therefore, as the enchanter's plant, was gathered by witches to do mischief in their incantations, yet, as Aubrey says, it 'hinders witches from their will,' a circumstance to which Drayton further refers when he speaks of the vervain as "gainst witchcraft much avayling." Now we understand why the children of Shakespeare's time hung vervain and dill with a horseshoe over the door.

In his eighth Eclogue, Virgil refers to vervain as a charm to recover lost love. Doubtless this was the verbena, the herba sacra employed in ancient Roman sacrifices, according to Pliny. In his day the bridal wreath was of verbena, gathered by the bride herself. 


\section{MINT FAMILY (Labiatae)}

\section{Mad-dog Skullcap or Helmet-flower; Mad weed; Hoodwort}

\section{Scutellaria lateriflora}

Flowers-Blue, varying to whitish; several or many, $1 / 4 \mathrm{in}$. long, growing in axils of upper leaves or in 1-sided spike-like racemes. Calyx 2-lipped, the upper lip with a helmet-like protuberance; corolla 2-lipped; the lower, 3-lobed lip spreading; the middle lobe larger than the side ones. Stamens, 4, in pairs, under the upper lip; upper pair the shorter; 1 pistil, the style unequally cleft in two. Stem: Square, smooth, leafy, branched, 8 in. to $2 \mathrm{ft}$. high. Leaves: Opposite, oblong to lance-shaped, thin, toothed, on slender pedicles, 1 to $3 \mathrm{in}$. long, growing gradually smaller toward top of stem. Fruit: 4 nutlets.

Preferred Habitat-Wet, shady ground.

Flowering Season-July-September.

Distribution-Uneven throughout United States and the British Possessions.

By the helmet-like appendage on the upper lip of the calyx, which to the imaginative mind of Linnaeus suggested Scutellum (a little dish), which children delight to spring open for a view of the four tiny seeds attached at the base when in fruit, one knows this to be a member of the skullcap tribe, a widely scattered genus of blue and violet two-lipped flowers, some small to the point of insignificance, like the present species, others showy enough for the garden, but all rich in nectar, and eagerly sought by their good friends, the bees. 
The Larger or Hyssop Skullcap (S. integrifolia) rarely has a dent in its rounded oblong leaves, which, like the stem, are covered with fine down. Its lovely, bright blue flowers, an inch long, the lips of about equal length, are grouped opposite each other at the top of a stem that never lifts them higher than two feet; and so their beauty is often concealed in the tall grass of roadsides and meadows and the undergrowth of woods and thickets, where they bloom from May to August, from southern New England to the Gulf of Mexico, westward to Texas.

Self-heal; Heal-all; Blue Curls; Heart-of-the-Earth; Brunella; Carpenter-weed

Prunella vulgaris

Flowers-Purple and violet, in dense spikes, somewhat resembling a clover head; from $1 / 2$ to $1 \mathrm{in}$. long in flower, becoming 4 times the length in fruit. Corolla tubular, irregularly 2-lipped, the upper lip darker and hood-like; the lower one 3lobed, spreading, the middle and largest lobe fringed; 4 twin-like stamens ascending under upper lip; filaments of the lower and longer pair 2-toothed at summit, one of the teeth bearing an anther, the other tooth sterile; style thread-like, shorter than stamens, and terminating in a 2-cleft stigma. Calyx 2-parted, half the length of corolla, its teeth often hairy on edges. Stem: 2 in. to $2 \mathrm{ft}$. high, erect or reclining, simple or branched. Leaves: Opposite, oblong. Fruit: 4 nutlets, round and smooth.

Preferred Habitat—Fields, roadsides, waste places.

Flowering Season-May-October

Distribution-North America, Europe, Asia.

This humble, rusty green plant, weakly lopping over the surrounding grass, so that often only its insignificant purple, clover-like flower-heads are visible, is another of those immigrants from the old countries which, having proved fittest in the fiercer struggle for existence there, has soon after its introduction here exceeded most of our more favored native flowers in numbers. Everywhere we find the heal-all, sometimes dusty and stunted by the roadside, sometimes truly beautiful in its fresh purple, violet, and white when perfectly developed under happy conditions. In England, where most flowers are deeper hued than with us, the heal-all is rich purple. What is the secret of this flower's successful march across three continents? As usual, the chief reason is to be found in the facility it offers insects to secure food; and the quantity of fertile seed it is therefore able to 
ripen as the result of their visits is its reward. Also, its flowering season is unusually long, and it is a tireless bloomer. It is finical in no respect; its sprawling stems root easily at the joints, and it is very hardy.

\section{Motherwort}

Leonurus Cardiaca

Flowers-Dull purple pink, pale purple, or white, small, clustered in axils of upper leaves. Calyx tubular, bell-shaped, with 5 rigid awl-like teeth; corolla 2lipped, upper lip arched, woolly without; lower lip 3-lobed, spreading, mottled; the tube with oblique ring of hairs inside. Four twin-like stamens, anterior pair longer, reaching under upper lip; style 2-cleft at summit. Stem: 2 to $5 \mathrm{ft}$. tall, straight, branched, leafy, purplish. Leaves: Opposite, on slender petioles; lower ones rounded, 2 to 4 in. broad, palmately cut into 2 to 5 lobes; upper leaves narrower, 3-cleft or 3-toothed.

Preferred Habitat-Waste places near dwellings.

Flowering Season-June-September.

Distribution-Nova Scotia southward to North Carolina, west to Minnesota and Nebraska. Naturalized from Europe and Asia.

How the bees love this generous, old-fashioned entertainer! One nearly always sees them clinging to the close whorls of flowers that are strung along the stem, and of course transferring pollen, in recompense, as they journey on. A more credulous generation imported the plant for its alleged healing virtues. What is the significance of its Greek name, meaning a lion's tail? Let no one suggest, by a far-stretched metaphor, that our grandmothers, in Revolutionary days, enjoyed pulling it to vent their animosity against the British.

Oswego Tea; Bee Balm; Indian's Plume; Fragrant Balm; Mountain Mint

Monarda didyma

Flowers-Scarlet, clustered in a solitary, terminal, rounded head of dark-red calices, with leafy bracts below it. Calyx narrow, tubular, sharply 5-toothed; corolla tubular, widest at the mouth, 2-lipped, 1 1/2 to 2 inches long; 2 long, antherbearing stamens ascending, protruding; 1 pistil; the style 2-cleft. Stem: 2 to $3 \mathrm{ft}$. tall. Leaves: Aromatic, opposite, dark green, oval to oblong lance-shaped, sharply saw-edged, of ten hairy beneath, petioled; upper leaves and bracts often red. 
Preferred Habitat-Moist soil, especially near streams, in hilly or mountainous regions.

Flowering Season-July-September.

Distribution-Canada to Georgia, west to Michigan.

Gorgeous, glowing scarlet heads of Bee Balm arrest the dullest eye, bracts and upper leaves often taking on blood-red color, too, as if it had dripped from the lacerated flowers. Where their vivid doubles are reflected in a shadowy mountain stream, not even the Cardinal Flower is more strikingly beautiful. Thrifty clumps transplanted from Nature's garden will spread about ours and add a splendor like the flowers of salvia, next of kin, if only the roots get a frequent soaking.

With even longer flower tubes than the Wild Bergamot's the Bee Balm belies its name, for, however frequently bees may come about for nectar when it rises high, only long-tongued bumblebees could get enough to compensate for their trouble. Butterflies, which suck with their wings in motion, plumb the depths. The rubythroated humming bird - to which the Brazilian salvia of our gardens has adapted itself-flashes about these whorls of Indian plumes just as frequently-of course transferring pollen on his needle-like bill as he darts from flower to flower. Even the protruding stamens and pistil take on the prevailing hue. Most of the small, blue, or purple flowered members of the mint family cater to bees by wearing their favorite color; the bergamot charms butterflies with magenta, and tubes so deep the short-tongued mob cannot pilfer their sweets; and from the frequency of the humming bird's visits, from the greater depth of the Bee Baln's tubes and their brilliant, flaring red-an irresistibly attractive color to the rubythroat - it would appear that this is a bird flower. Certainly its adaptation is quite as perfect as the salvia's. Mischievous bees and wasps steal nectar they cannot reach legitimately through bungholes of their own making in the bottom of the slender casks.

\section{Wild Bergamot}

Monarda fistulosa

Flowers-Extremely variable, purplish lavender, magenta, rose, pink, yellowish pink, or whitish, dotted; clustered in a solitary, nearly flat terminal head. Calyx tubular, narrow, 5-toothed, very hairy within. Corolla 1 to $1-1 / 2$ in. long, tubular, 2-lipped, upper lip erect, toothed; lower lip spreading, 3-lobed, middle lobe 
longest; 2 anther-bearing stamens protruding; 1 pistil; the style 2-lobed. Stem: 2 to $3 \mathrm{ft}$. high, rough, branched. Leaves: Opposite, lance-shaped, saw-edged, on slender petioles; aromatic; bracts and upper leaves whitish or the color of flower.

Preferred Habitat-Open woods, thickets, dry rocky hills.

Flowering Season-June-September.

Distribution-Eastern Canada and Maine, westward to Minnesota, south to Gulf of Mexico.

Only a few bergamot flowers open at a time; the rest of the slightly rounded head, thickly set with hairy calices, looks as if it might be placed in a glass cup and make an excellent penwiper. If the cultivated human eye (and stomach) revolt at magenta, it is ever a favorite shade with butterflies. They flutter in ecstasy over the gay flowers; indeed, they are the principal visitors and benefactors, for the erect corollas, exposed organs, and level-topped heads are well adapted to their requirements. 


\section{NIGHTSHADE FAMILY (Solanaceae)}

Nightshade; Blue Bindweed; Felonwort; Bittersweet; Scarlet or Snake Berry; Poison-flower; Woody Nightshade

\section{Solanum Dulcamara}

Flowers-Blue, purple, or, rarely, white with greenish spots on each lobe; about $1 / 2$ in. broad, clustered in slender, drooping cymes. Calyx 5-lobed, oblong, persistent on the berry; corolla deeply, sharply 5-cleft, wheel-shaped, or points curved backward; 5 stamens inserted on throat, yellow, protruding, the anthers united to form a cone; stigma small. Stem: Climbing or straggling, woody below, branched, 2 to $8 \mathrm{ft}$. long. Leaves: Alternate, 2 to $4 \mathrm{in}$. long, 1 to $21 / 2 \mathrm{in}$. wide, pointed at the apex, usually heart-shaped at base; some with 2 distinct leaflets below on the petiole, others have leaflets united with leaf like lower lobes or wings. Fruit: A bright red, oval berry.

Preferred Habitat-Moist thickets, fence rows.

Flowering Season-May-September.

Distribution-United States east of Kansas, north of New Jersey. Canada, Europe, and Asia.

More beautiful than the graceful flowers are the drooping cymes of bright berries, turning from green to yellow, then to orange and scarlet, in the tangled thicket by the shady roadside in autumn, when the unpretending, shrubby vine, that has crowded its way through the rank midsummer vegetation, becomes a joy to the 
eye. Another bittersweet, so-called, festoons the hedgerows with yellow berries which, bursting, show their scarlet-coated seeds. Rose hips and mountain-ash berries, among many other conspicuous bits of color, arrest attention, but not for us were they designed. Now the birds are migrating, and, hungry with then-long flight, they gladly stop to feed upon fare so attractive. Hard, indigestible seeds traverse the alimentary canal without alteration and are deposited many miles from the parent that bore them. Nature's methods for widely distributing plants cannot but stir the dullest imagination.

Jamestown Weed; Thorn Apple; Stramonium; Jimson Weed; Devil's Trumpet

\section{Datura Stramonium}

Flowers-Showy, large, about $4 \mathrm{in}$. high, solitary, erect, growing from the forks of branches. Calyx tubular, nearly half as long as the corolla, 5-toothed, prismatic; corolla funnel-form, deep-throated, the spreading limb 2 in. across or less, plaited, 5-pointed; stamens 5; 1 pistil. Stem: Stout, branching, smooth, 1 to $5 \mathrm{ft}$. high. Leaves: Alternate, large, rather thin, petioled, egg-shaped in outline, the edges irregularly wavy-toothed or angled; rank-scented. Fruit: A densely prickly, egg-shaped capsule, the lower prickles smallest. The seeds and stems contain a powerful narcotic poison.

Preferred Habitat-Light soil, fields, waste land near dwellings, rubbish heaps.

Flowering Season-June-September.

Distribution-Nova Scotia to the Gulf of Mexico, westward beyond the Mississippi.

When we consider that there are more than five million Gypsies wandering about the globe, and that the narcotic seeds of the Thorn Apple, which apparently heal, as well as poison, have been a favorite medicine of theirs for ages, we can understand at least one means of the weed reaching these shores from tropical Asia. (Hindoo, dhatura.) Our Indians, who call it "white man's plant," associate it with the Jamestown settlement-a plausible connection, for Raleigh's colonists would have been likely to carry with them to the New World the seeds of an herb yielding an alkaloid more esteemed in the England of their day than the alkaloid of opium known as morphine. Daturina, the narcotic, and another product, known in medicine as stramonium, smoked by asthmatics, are by no means despised by up-to-date practitioners. Were it not for the rank odor of its leaves, the vigorous weed, coarse as it is, would be welcome in men's gardens. Indeed, many of its similar relatives adorn them. The fragrant petunia and tobacco plants of the flower beds, the potato, tomato, and egg-plant in the kitchen garden, call it cousin. 


\section{FIGWORT FAMILY (Scrophulariaceae)}

Great Mullein; Velvet or Flannel Plant; Mullein Dock; Aaron's Rod

Verbascum Thapsus

Flowers-Yellow, 1 in. across or less, seated around a thick, dense, elongated spike. Calyx 5-parted; corolla of 5 rounded lobes; 5 anther-bearing stamens, the 3 upper ones short, woolly; 1 pistil. Stem: Stout, 2 to $7 \mathrm{ft}$. tall, densely woolly, with branched hairs. Leaves: Thick, pale green, velvety-hairy, oblong, in a rosette oil the ground; others alternate, strongly clasping the stem.

Preferred Habitat-Dry fields, banks, stony waste land.

Flowering Season-June-September.

Distribution-Minnesota and Kansas, eastward to Nova Scotia and Florida. Europe.

Leaving the fluffy thistle-down he has been kindly scattering to the four winds, the goldfinch spreads his wings for a brief, undulating flight, singing in waves also as he goes to where tall, thick-set mullein stalks stand like sentinels above the stony pasture. Here companies of the exquisite little black and yellow minstrels delight to congregate with their sombre families and feast on the seeds that rapidly follow the erratic flowers up the gradually lengthening spikes.

"I have come three thousand miles to see the mullein cultivated in a garden, and christened the velvet plant," says John Burroughs in "An October Abroad." But 
even in England it grows wild, and much more abundantly in southern Europe, while its specific name is said to have been given it because it was so common in the neighborhood of Thapsus; but whether the place of that name in Africa, or the Sicilian town mentioned by Ovid and Virgil, is not certain. Strange that Europeans should labor under the erroneous impression that this mullein is native to America, whereas here it is only an immigrant from their own land. Rapidly taking its course of empire westward from our seaports into which the seeds smuggled their passage among the ballast, it is now more common in the Eastern states, perhaps, than any native. Forty or more folk-names have been applied to it, mostly in allusion to its alleged curative powers, its use for candle-wick and funeral torches in the Middle Ages. The generic title, first used by Pliny, is thought to be a corruption of Barbascum (= with beards) in allusion to the hairy filaments or, as some think, to the leaves.

Of what use is this felt-like covering to the plant? The importance of protecting the delicate, sensitive, active cells from intense light, draught, or cold, have led various plants to various practices; none more common, however, than to develop hairs on the epidermis of their leaves, sometimes only enough to give it a downy appearance, sometimes to coat it with felt, as in this case, where the hairs branch and interlace. Fierce sunlight in the exposed dry situations where the mullein grows; prolonged drought, which often occurs at flowering season, when the perpetuation of the species is at stake; and the intense cold which the exquisite rosettes formed by year-old plants must endure through a winter before they can send up a flower-stalk the second spring-these trials the well-screened, juicy, warm plant has successfully surmounted through its coat of felt. Humming birds have been detected gathering the hairs to line their tiny nests. The light, strong stalk makes almost as good a cane as bamboo, especially when the root end, in running under a stone, forms a crooked handle. Pale country beauties rub their cheeks with the velvety leaves to make them rosy.

\section{Moth Mullein}

\section{Verbascum Blattaria}

Flowers-Yellow, or frequently white, 5-parted, about 1 in. broad, marked with brown; borne on spreading pedicles in a long, loose raceme; all the filaments with violet hairs; 1 protruding pistil. Stem: Erect, slender, simple, about $2 \mathrm{ft}$. high, sometimes less, or much taller. Leaves: Seldom present at flowering time; oblong to ovate, toothed, mostly sessile, smooth.

Preferred Habitat—Dry, open waste land; roadsides, fields. 
Flowering Season-June-November.

Distribution-Naturalized from Europe and Asia, more or less common throughout the United States and Canada.

"Of beautiful weeds quite a long list might be made without including any of the so-called wild flowers," says John Burroughs. "A favorite of mine is the little Moth Mullein that blooms along the highway, and about the fields, and maybe upon the edge of the lawn." Even in winter, when the slender stem, set with round brown seed-vessels, rises above the snow, the plant is pleasing to the human eye, as it is to that of hungry birds.

Butter-and-eggs; Yellow Toadflax; Eggs-and-bacon; Flaxweed; Brideweed

\section{Linaria vulgaris}

Flowers - Light canary yellow and orange, $1 \mathrm{in}$. long or over, irregular, borne in terminal, leafy-bracted spikes. Corolla spurred at the base, 2-lipped, the upper lip erect, 2-lobed; the lower lip spreading, 3-lobed, its base an orange-colored palate closing the throat; 4 stamens in pairs within; 1 pistil. Stem: 1 to $3 \mathrm{ft}$. tall, slender, leafy. Leaves: Pale, grass-like.

Preferred Habitat-Waste land, roadsides, banks, fields.

Flowering Season-June-October.

Distribution-Nebraska and Manitoba, eastward to Virginia and Nova Scotia. Europe and Asia.

An immigrant from Europe, this plebeian perennial, meekly content with waste places, is rapidly inheriting the earth. Its beautiful spikes of butter-colored cornucopias, apparently holding the yolk of a diminutive egg, emit a cheesy odor, suggesting a close dairy. Perhaps half the charm of the plant-and its charms increase greatly when it is grown in a garden-consists in the pale bluish-green grass-like leaves with a bloom on the surface, which are put forth so abundantly from the sterile shoots.

Blue or Wild Toadflax; Blue Linaria

Linaria canadensis 
Flowers-Pale blue to purple, small, irregular, in slender spikes. Calyx 5 pointed;corolla 2-lipped, with curved spur longer than its tube, which is nearly closed by a white, 2-ridged projection or palate; the upper lip erect, 2-lobed; lower lip 3lobed, spreading. Stamens 4, in pairs, in throat; 1 pistil. Stem: Slender, weak, of sterile shoots, prostrate; flowering stem, ascending or erect, $4 \mathrm{in}$. to $2 \mathrm{ft}$. high. Leaves: Small, linear, alternately scattered along stem, or oblong in pairs or threes on leafy sterile shoots.

Preferred Habitat-Dry soil, gravel or sand.

Flowering Season-May-October.

Distribution-North, Central, and South Americas.

Wolf, rat, mouse, sow, cow, cat, snake, dragon, dog, toad, are among the many animal prefixes to the names of flowers that the English country people have given for various and often most interesting reasons. Just as dog, used as a prefix, expresses an idea of worthlessness to them, so toad suggests a spurious plant; the toadflax being made to bear what is meant to be an odious name because before flowering it resembles the true flax, linum, from which the generic title is derived.

\section{Hairy Beard-tongue}

Pentstemon hirsutus (P. pubescens)

Flowers-Dull violet or lilac and white, about $1 \mathrm{in}$. long, borne in a loose spike. Calyx 5-parted, the sharply pointed sepals overlapping; corolla, a gradually inflated tube widening where the mouth divides into a 2-lobed upper lip and a 3-lobed lower lip; the throat nearly closed by hairy palate at base of lower lip; sterile fifth stamen densely bearded for half its length; 4 anther-bearing stamens, the anthers divergent. Stem: 1 to $3 \mathrm{ft}$. high, erect, downy above. Leaves: Oblong to lanceshaped, upper ones seated on stem; lower ones narrowed into petioles.

Preferred Habitat-Dry or rocky fields, thickets, and open woods.

Flowering Season-May-July.

Distribution-Ontario to Florida, Manitoba to Texas.

It is the densely bearded, yellow, fifth stamen (pente = five, stemon = a stamen) which gives this flower its scientific name and its chief interest to the structural 
botanist. From the fact that a blossom has a lip in the centre of the lower half of its corolla, that an insect must use as its landing place, comes the necessity for the pistil to occupy a central position. Naturally, a fifth stamen would be only in its way, an encumbrance to be banished in time. In the figwort, for example, we have seen the fifth stamen reduced, from long sterility, to a mere scale on the roof of the corolla tube; in other lipped flowers, the useless organ has disappeared; but in the beard-tongue, it goes through a series of curious curves from the upper to the under side of the flower to get out of the way of the pistil. Yet it serves an admirable purpose in helping close the mouth of the flower, which the hairy lip alone could not adequately guard against pilferers. A long-tongued bee, thrusting in his head up to his eyes only, receives the pollen in his face. The blossom is male (staminate) in its first stage and female (pistillate) in its second. A western species of the beard-tongue has been selected by gardeners for hybridizing into showy but often less charming flowers.

Snake-head; Turtle-head; Balmony; Shellflower; Cod-head

Chelone glabra

Flowers-White tinged with pink, or all white, about $1 \mathrm{in}$. long, growing in a dense, terminal cluster. Calyx 5-parted, bracted at base; corolla irregular broadly tubular, 2-lipped; upper lip arched, swollen, slightly notched;, lower lip 3-lobed, spreading, woolly within; 5 stamens, 1 sterile, 4 in pairs, anther-bearing, woolly; 1 pistil. Stem: 1 to $3 \mathrm{ft}$. high, erect, smooth, simple, leafy. Leaves: Opposite, lance-shaped, saw-edged.

Preferred Habitat-Ditches, beside streams, swamps.

Flowering Season-July-September.

Distribution-Newfoundland to Florida, and half way across the continent.

It requires something of a struggle for even so strong and vigorous an insect as the bumblebee to gain admission to this inhospitable-looking flower before maturity; and even he abandons the attempt over and over again in its earliest stage before the little heart-shaped anthers are prepared to dust him over. As they mature, it opens slightly, but his weight alone is insufficient to bend down the stiff, yet elastic, lower lip. Energetic prying admits first his head, then he squeezes his body through, brushing past the stamens as he finally disappears inside. At the moment when he is forcing his way in, causing the lower lip to spring up and down, the eyeless turtle seems to chew and chew until the most sedate beholder must smile 
at the paradoxical show. Of course it is the bee that is feeding, though the flower would seem to be masticating the bee with the keenest relish! The counterfeit tortoise soon disgorges its lively mouthful, however, and away flies the bee, carrying pollen on his velvety back to rub on the stigma of an older flower.

Monkey-flower

Mimulus ringens

Flowers-Purple, violet, or lilac, rarely whitish; about 1 in. long, solitary, borne on slender footstems from axils of upper leaves. Calyx prismatic, 5-angled, 5toothed; corolla irregular, tubular, narrow in throat, 2-lipped; upper lip 2-lobed, erect; under lip 3-lobed, spreading; 4 stamens, a long and a short pair, inserted on corolla tube; 1 pistil with 2-lobed, plate-like stigma. Stem: Square, erect, usually branched, 1 to $3 \mathrm{ft}$. high. Leaves: Opposite, oblong to lance-shaped, saw-edged, mostly seated on stem.

Preferred Habitat—Swamps, beside streams and ponds.

Flowering Season-June-September.

Distribution-Manitoba, Nebraska, and Texas, eastward to Atlantic Ocean.

Imaginative eyes see what appears to them the gaping (ringens) face of a little ape or buffoon (mimulus) in this common flower whose drolleries, such as they are, call forth the only applause desired - the buzz of insects that become pollen-laden during the entertainment.

Common Speedwell; Fluellin; Paul's Betony; Groundhele

Veronica officinalis

Flowers-Pale blue, very small, crowded on spike-like racemes from axils of leaves, often from alternate axils. Calyx 4-parted; corolla of 4 lobes, lower lobe commonly narrowest; 2 divergent stamens inserted at base and on either side of upper corolla lobe; a knob-like stigma on solitary pistil. Stem: From 3 to $10 \mathrm{in.}$ long, hairy, often prostrate, and rooting at joints. Leaves: Opposite, oblong, obtuse, saw-edged, narrowed at base. Fruit: Compressed heart-shaped capsule, containing numerous flat seeds.

Preferred Habitat—Dry fields, uplands, open woods. 
Flowering Season-May-August.

Distribution-From Michigan and Tennessee eastward, also from Ontario to Nova Scotia. Probably an immigrant from Europe and Asia.

An ancient tradition of the Roman Church relates that when Jesus was on His way to Calvary, He passed the home of a certain Jewish maiden, who, when she saw drops of agony on His brow, ran after Him along the road to wipe His face with her kerchief. This linen, the monks declared, ever after bore the impress of the sacred features - vera iconica, the true likeness. When the Church wished to canonize the pitying maiden, an abbreviated form of the Latin words was given her, St. Veronica, and her kerchief became one of the most precious relics at St. Peter's, where it is said to be still preserved. Medieval flower lovers, whose piety seems to have been eclipsed only by their imaginations, named this little flower from a fancied resemblance to the relic. Of course, special healing virtue was attributed to the square of pictured linen, and since all could not go to Rome to be cured by it, naturally the next step was to employ the common, wayside plant that bore the saint's name. Mental healers will not be surprised to learn that because of the strong popular belief in its efficacy to cure all fleshly ills, it actually seemed to possess miraculous powers. For scrofula it was said to be the infallible remedy, and presently we find Linnaeus grouping this flower, and all its relatives, under the family name of Scrofulariaceae.

American Brooklime

\section{Veronica americana}

Flowers-Light blue to white, usually striped with deep blue or purple; structure of flower similar to that of $\mathrm{V}$. officinalis, but borne in long, loose racemes branching outward on stems that spring from axils of most of the leaves. Stem: Without hairs, usually branched, 6 in. to $3 \mathrm{ft}$. long, lying partly on ground and rooting from lower joints. Leaves: Oblong, lance-shaped, saw-edged, opposite, petioled, and lacking hairs; 1 to $3 \mathrm{in}$. long, $1 / 4$ to $1 \mathrm{in}$. wide. Fruit: A nearly round, compressed, but not flat, capsule with flat seeds in 2 cells.

Preferred Habitat - In brooks, ponds, ditches, swamps.

Flowering Season-April-September.

Distribution-From Atlantic to Pacific, Alaska to California and New Mexico, Quebec to Pennsylvania. 
This, the perhaps most beautiful native speedwell, whose sheets of blue along the brookside are so frequently mistaken for masses of forget-me-nots by the hasty observer, of course shows marked differences on closer investigation; its tiny blue flowers are marked with purple pathfinders, and the plant is not hairy, to mention only two. But the poets of England are responsible for most of whatever confusion still lurks in the popular mind concerning these two flowers. Speedwell, a common medieval benediction from a friend, equivalent to our farewell or adieu, and forget-me-not of similar intent, have been used interchangeably by some writers in connection with parting gifts of small blue flowers. It was the germander speedwell that in literature and botanies alike was most commonly known as the forget-me-not for more than two hundred years, or until only fifty years ago. When the Mayflower and her sister ships were launched, "Speedwell" was considered a happier name for a vessel than it proved to be.

Culver's-root; Culver's Physic

Veronica virginica (Leplandra virginica)

Flowers-Small, white or rarely bluish, crowded in dense spike-like racemes 3 to 9 in. long, usually several spikes at top of stem or from upper axils. Calyx 4-parted, very small; corolla tubular, 4-lobed; 2 stamens protruding; 1 pistil. Stem: Straight, erect, usually unbranched, 2 to $7 \mathrm{ft}$. tall. Leaves: Whorled, from 3 to 9 in a cluster, lance-shaped or oblong, and long-tapering, sharply saw-edged.

Preferred Habitat-Rich, moist woods, thickets, meadows.

Flowering Season-June-September.

Distribution-Nova Scotia to Alabama, west to Nebraska.

"The leaves of the herbage at our feet," says Ruskin, "take all kinds of strange shapes, as if to invite us to examine them. Star-shaped, heart-shaped, spearshaped, arrow-shaped, fretted, fringed, cleft, furrowed, serrated, in whorls, in tufts, in wreaths, in spires, endlessly expressive, deceptive, fantastic, never the same from footstalks to blossom, they seem perpetually to tempt our watchfulness, and take delight in outstripping our wonder." Doubtless light is the factor with the greatest effect in determining the position of the leaves on the stem, if not their shape. After plenty of light has been secured, any aid they may render the flowers in increasing their attractiveness is gladly rendered. Who shall deny that the brilliant foliage of the sumacs, the dogwood, and the pokeweed in 
autumn does not greatly help them in attracting the attention of migrating birds to their fruit, whose seeds they wish distributed? Or that the clustered leaves of the Dwarf Cornel and Culver's-root, among others, do not set off to great advantage their white flowers which, when seen by an insect flying overhead, are made doubly conspicuous by the leafy background formed by the whorl?

\section{Downy False Foxglove}

\section{Gerardia flava (Dasystoma flava)}

Flowers-Pale yellow, 1-1/2 to 2 in. long; in showy, terminal, leafy bracted racemes. Calyx bell-shaped, 5 -toothed; corolla funnel form, the 5 lobes spreading, smooth outside, woolly within; 4 stamens in pairs, woolly; 1 pistil. Stem: Grayish, downy, erect, usually simple, 2 to $4 \mathrm{ft}$. tall. Leaves: Opposite, lower ones oblong in outline, more or less irregularly lobed and toothed; upper ones small, entire.

Preferred Habitat-Gravelly or sandy soil, dry thickets, open woods.

Flowering Season-July-August.

Distribution-"Eastern Massachusetts to Ontario and Wisconsin, south to southern New York, Georgia, and Mississippi" (Britton and Brown).

In the vegetable kingdom, as in the spiritual, all degree of backsliding sinners may be found, each branded with a mark of infamy according to its deserts. We see how the dodder vine lost both leaf and roots after it consented to live wholly by theft of its hard-working host's juices through suckers that penetrate to the vitals; how the Indian Pipe's blanched face tells the story of guilt perpetrated under cover of darkness in the soil below; how the broom-rape and beech-drops lost their honest green color; and, finally, the foxgloves show us plants with their faces so newly turned toward the path of perdition, their larceny so petty, that only the expert in criminal botany cases condemns them. Like its cousins the gerardias, the Downy False Foxglove is only a partial parasite, attaching its roots by disks or suckers to the roots of white oak or witch hazel; not only that, but, quite as frequently, groping blindly in the dark, it fastens suckers on its own roots, actually thieving from itself? It is this piratical tendency which makes transplanting of foxgloves into our gardens so very difficult, even when lifted with plenty of their beloved vegetable mould. The term false foxglove, it should be explained, is by no means one of reproach for dishonesty; it was applied simply to distinguish this group of plants from the true foxgloves cultivated, not wild, here, which yield digitalis to the doctors. 


\section{Large Purple Gerardia}

\section{Gerardia purpurea}

Flowers-Bright purplish pink, deep magenta, or pale to whitish, about $1 \mathrm{in}$. long and broad, growing along the rigid, spreading branches. Calyx 5-toothed; corolla funnel form, the tube much inflated above and spreading into 5 unequal, rounded lobes, spotted within, or sometimes downy; 4 stamens in pairs, the filaments hairy; 1 pistil. Stem: 1 to $2-1 / 2 \mathrm{ft}$. high, slender, branches erect or spreading. Leaves: Opposite, very narrow, 1 to $1-1 / 2$ in. long.

Preferred Habitat—Low fields and meadows; moist, sandy soil.

Flowering Season-August-October.

Distribution-Northern United States to Florida, chiefly along Atlantic Coast.

It is a special pity to gather the gerardias, which, as they grow, seem to enjoy life to the full, and when picked, to be so miserable they turn black as they dry. Like their relatives the foxgloves, they are difficult to transplant except with a large ball of soil, because it is said they are more or less parasitic, fastening their roots on those of other plants. When robbery becomes flagrant, Nature brands sinners in the vegetable kingdom by taking away their color, and perhaps their leaves, as in the case of the broom-rape and Indian Pipe; but the fair faces of the gerardias and foxgloves give no hint of the petty thefts committed under cover of darkness in the soil below.

Scarlet Painted Cup; Indian Paint-brush

Castilleja coccinea

Flowers-Greenish yellow, enclosed by broad, vermilion, 3-cleft floral bracts; borne in a terminal spike. Calyx flattened, tubular, cleft above and below into 2 lobes; usually green, sometimes scarlet; corolla very irregular, the upper lip long and arched, the short lower lip 3-lobed; 4 unequal stamens; 1 pistil. Stem: 1 to 2 ft. high, usually unbranched, hairy. Leaves: Lower ones tufted, oblong, mostly uncut; stem leaves deeply cleft into 3 to 5 segments, sessile.

Preferred Habitat-Meadows, prairies, mountains, moist, sandy soil.

Flowering Season-May-July. 
Distribution-Maine to Manitoba, south to Virginia, Kansas, and Texas.

Here and there the meadows show a touch of as vivid a red as that in which Vibert delighted to dip his brush.

\author{
"Scarlet tufts \\ Are glowing in the green like flakes of fire; \\ The wanderers of the prairie know them well, \\ And call that brilliant flower the "painted cup."
}

Thoreau, who objected to this name, thought flame flower a better one, the name the Indians gave to Oswego Tea; but here the floral bracts, not the flowers themselves, are on fire. Whole mountainsides in the Canadian Rockies are ablaze with the Indian Paint-brushes that range in color there from ivory white and pale salmon through every shade of red to deep maroon-a gorgeous conflagration of color. Lacking good, honest, deep green, one suspects from the yellowish tone of calices, stem, and leaves that this plant is something of a thief. That it still possesses foliage, proves only petty larceny against it, similar to the foxglove's. The roots of our painted cup occasionally break in and steal from the roots of its neighbors such juices as the plant must work over into vegetable tissue. Therefore it still needs leaves, indispensable parts of a digestive apparatus. Were it wholly given up to piracy, like the dodder, or as parasitic as the Indian Pipe, even the green and the leaf that it hath would be taken away.

Wood Betony; Lousewort; Beefsteak Plant; High Heal-all

Pedicularis canadensis

Flowers-Greenish yellow and purplish red, in a short, dense spike. Calyx oblique, tubular, cleft on lower side, and with 2 or 3 scallops on upper; corolla about 3/4 in. long, 2-lipped, the upper lip arched, concave, the lower 3-lobed; 4 stamens in pairs; 1 pistil. Stems: Clustered, simple, hairy, 6 to 18 in. high. Leaves: Mostly tufted, oblong lance-shaped in outline, and pinnately lobed.

Preferred Habitat-Dry, open woods and thickets.

Flowering Season-April-June.

Distribution-Nova Scotia to Florida, westward to Manitoba, Colorado, and Kansas. 
When the Italians wish to extol some one they say, "He has more virtues than betony," alluding, of course, to the European species, Betonica officinalis, a plant that was worn about the neck and cultivated in cemeteries during the Middle Ages as a charm against evil spirits; and prepared into plasters, ointments, syrups, and oils, was supposed to cure every ill that flesh is heir to. Our commonest American species fulfils its mission in beautifying roadside banks, and dry open woods and copses with thick, short spikes of bright flowers, that rise above large rosettes of coarse, hairy, fern-like foliage. At first, these flowers, beloved of bumblebees, are all greenish yellow; but as the spike lengthens with increased bloom, the arched, upper lip of the blossom becomes dark purplish red, the lower one remains pale yellow, and the throat turns reddish, while some of the beefsteak color often creeps into stems and leaves as well.

Farmers once believed that after their sheep fed on the foliage of this group of plants a skin disease, produced by a certain tiny louse (pediculus), would attack them-hence our innocent betony's repellent name. 


\section{BROOM-RAPE FAMILY (Orobanchaceae)}

\section{Beech-drops}

\section{Epifagus virginiana}

Flowers-Small, dull purple and white, tawny, or brownish striped; scattered along loose, tiny bracted, ascending branches. Stem: Brownish or reddish tinged, slender, tough, branching above, $6 \mathrm{in}$. to $2 \mathrm{ft}$. tall, from brittle, fibrous roots.

Preferred Habitat-Under beech, oak, and chestnut trees.

Flowering Season-August-October.

Distribution-New Brunswick, westward to Ontario and Missouri, south to the Gulf states.

Nearly related to the broom-rape is this less attractive pirate, a taller, brownishpurple plant, with a disagreeable odor, whose erect, branching stem without leaves is still furnished with brownish scales, the remains of what were once green leaves in virtuous ancestors, no doubt. But perhaps even these relics of honesty may one day disappear. Nature brands every sinner somehow; and the loss of green from a plant's leaves may be taken as a certain indication that theft of another's food stamps it with this outward and visible sign of guilt. The grains of green to which foliage owes its color are among the most essential of products to honest vegetables that have to grub in the soil for a living, since it is only in such cells as contain it that assimilation of food can take place. As chlorophyll, or leaf-green, acts 
only under the influence of light and air, most plants expose all the leaf surface possible; but a parasite, which absorbs from others juices already assimilated, certainly has no use for chlorophyll, nor for leaves either; and in the broom-rape, beech-drops, and Indian Pipe, among other thieves, we see leaves degenerated into bracts more or less without color, according to the extent of their crime. Now they cannot manufacture carbo-hydrates, even if they would, any more than fungi can. The beech-drop bears cleistogamous or blind flowers in addition to the few showy ones needed to attract insects. 


\section{MADDER FAMILY (Rubiaceae)}

Partridge Vine, Twin-berry; Mitchella Vine; Squaw-berry

Mitchella repens

Flowers - Waxy, white (pink in bud), fragrant, growing in pairs at ends of the branches. Calyx usually 4 -lobed; corolla funnel form, about $1 / 2 \mathrm{in}$. long, the 4 spreading lobes bearded within; 4 stamens inserted on corolla throat; 1 style with 4 stigmas; the ovaries of the twin flowers united (The style is long when the stamens are short, or vice versa.) Stem: Slender, trailing, rooting at joints, 6 to 12 in. long, with numerous erect branches. Leaves: Opposite, entire, short petioled, oval or rounded, evergreen, dark, sometimes white veined. Fruit: A small, red, edible, double berry-like drupe.

Preferred Habitat-Woods; usually, but not always, dry ones.

Flowering Season-April-June. Sometimes again in autumn.

Distribution-Nova Scotia to the Gulf states, westward to Minnesota and Texas.

A carpet of these dark, shining, little evergreen leaves, spread at the foot of forest trees, whether sprinkled over in June with pairs of waxy, cream-white, pinktipped, velvety, lilac-scented flowers that suggest attenuated arbutus blossoms, or with coral-red "berries" in autumn and winter, is surely one of the loveliest sights in the woods. Transplanted to the home garden in closely packed, generous clumps, with plenty of leaf mould, or, better still, chopped sphagnum, about them, they soon spread into thick mats in the rockery, the hardy fernery, or about 
the roots of rhododendrons and the taller shrubs that permit some sunlight to reach them. No woodland creeper rewards our care with greater luxuriance of growth. Growing near our homes, the Partridge Vine offers an excellent opportunity for study.

What endless confusion arises through giving the same popular folk-names to different species! The Bob White, which is called quail in New England or wherever the ruffed grouse is known as partridge, is called partridge in the Middle and Southern states, where the ruffed grouse is known as pheasant. But as both these distributing agents, like most winter rovers, whether bird or beast, are inordinately fond of this tasteless partridge berry, as well as of the spicy fruit of quite another species, the aromatic wintergreen, which shares with it a number of common names, every one may associate whatever bird and berry best suit him. The delicious little twin-flower beloved of Linnaeus also comes in for a share of lost identity through confusion with the Partridge Vine.

Button-bush; Honey-balls; Globe-flower; Button-ball Shrub; River-bush

\section{Cephalanthus occidentalis}

Flowers-Fragrant, white, small, tubular, hairy within, 4-parted, the long, yellowtipped style far protruding; the florets clustered on a fleshy receptacle, in round heads (about $1 \mathrm{in}$. across), elevated on long peduncles from leaf axils or ends of branches. Stem: A shrub 3 to $12 \mathrm{ft}$. high. Leaves: Opposite or in small whorls, petioled, oval, tapering at the tip, entire.

Preferred Habitat-Beside streams and ponds; swamps, low ground.

Flowering Season-June-September.

Distribution-New Brunswick to Florida and Cuba, westward to Arizona and California.

Delicious fragrance, faintly suggesting jessamine, leads one over marshy ground to where the button-bush displays dense, creamy-white globes of bloom, heads that Miss Lounsberry aptly likens to "little cushions full of pins." Not far away the sweet breath of the white-spiked Clethra comes at the same season, and one cannot but wonder why these two bushes, which are so beautiful when most garden shrubbery is out of flower, should be left to waste their sweetness, if not on desert air exactly, on air that blows far from the homes of men. Partially shaded and sheltered positions near a house, if possible, suit these water-lovers admirably. 
Cultivation only increases their charms. We have not so many fragrant wild flowers that any can be neglected. John Burroughs, who included the blossoms of several trees in his list of fragrant ones, found only thirty-odd species in New England and New York.

Bluets; Innocence; Houstonia; Quaker Ladies; Quaker Bonnets; Venus' Pride

\section{Houstonia caerulea}

Flowers-Very small, light to purplish blue or white, with yellow centre, and borne at end of each erect slender stem that rises from 3 to $7 \mathrm{in.} \mathrm{high.} \mathrm{Corolla}$ funnel-shaped, with 4 oval, pointed, spreading lobes that equal the slender tube in length; rarely the corolla has more divisions; 4 stamens inserted on tube of corolla; 2 stigmas; calyx 4-lobed. Leaves: Opposite, seated on stem, oblong, tiny; the lower ones spatulate. Fruit: A 2-lobed pod, broader than long, its upper half free from calyx; seeds deeply concave. Root-stalk: Slender, spreading, forming dense tufts.

Preferred Habitat-Moist meadows, wet rocks and banks.

Flowering Season-April-July, or sparsely through summer.

Distribution-Eastern Canada and United States west to Michigan, south to Georgia and Alabama.

Millions of these dainty wee flowers, scattered through the grass of moist meadows and by the wayside, reflect the blue and the serenity of heaven in their pure, upturned faces. Where the white variety grows, one might think a light snowfall had powdered the grass, or a milky way of tiny floral stars had streaked a terrestrial path. Linnaeus named the flower for Doctor Houston, a young English physician, botanist, and collector, who died in South America in 1733, after an exhausting tramp about the Gulf of Mexico. Flies, beetles, and the common little meadow fritillary butterfly visit these flowers. But small bees are best adapted to it.

John Burroughs found a single bluet in blossom one January, near Washington, when the clump of earth on which it grew was frozen solid. A pot of roots gathered in autumn and placed in a sunny window has sent up a little colony of starlike flowers throughout a winter. 


\section{BLUEBELL FAMILY (Campanulaceae)}

Harebell or Hairbell; Blue Bells of Scotland; Lady's Thimble

Campanula rotundifolia

Flowers-Bright blue or violet-blue, bell-shaped, 1/2 in. long, or over, drooping from hair-like stalks. Calyx of 5-pointed, narrow, spreading lobes; 5 slender stamens alternate with lobes of corolla, and borne on summit of calyx tube, which is adherent to ovary; 1 pistil with 3 stigmas in maturity only. Stem: Very slender, 6 in. to $3 \mathrm{ft}$. high, often several from same root; simple or branching. Leaves: Lower ones nearly round, usually withered and gone by flowering season; stem leaves narrow, pointed, seated on stem. Fruit: An egg-shaped, pendent, 3-celled capsule with short openings near base; seeds very numerous, tiny.

Preferred Habitat-Moist rocks, uplands.

Flowering Season-June-September.

Distribution-Arctic regions of Europe, Asia, and America; southward on this continent, through Canada to New Jersey and Pennsylvania; westward to Nebraska, to Arizona in the Rockies, and to California in the Sierra Nevadas.

The inaccessible crevice of a precipice, moist rocks sprayed with the dashing waters of a lake or some tumbling mountain stream, wind-swept upland meadows, and shady places by the roadside may hold bright bunches of these hardy bells, swaying with exquisite grace on tremulous, hair-like stems that are fitted to 
withstand the fiercest mountain blasts, however frail they appear. How dainty, slender, tempting these little flowers are! One gladly risks a watery grave or broken bones to bring down a bunch from its aerial cranny.

Venus' Looking-glass; Clasping Bellflower

Specularia perfoliata (Legouzia perfoliata)

Flowers-Violet blue, from $1 / 2$ to 3/4 in. across; solitary or 2 or 3 together, seated, in axils of upper leaves. Calyx lobes varying from 3 to 5 in earlier and later flowers, acute, rigid; corolla a 5-spoked wheel; 5 stamens; 1 pistil with 3 stigmas. Stem: 6 in. to $2 \mathrm{ft}$. long, hairy, densely leafy, slender, weak. Leaves: Round, clasped about stem by heart-shaped base.

Preferred Habitat-Sterile waste places, dry woods.

Flowering Season-May-September.

Distribution-From British Columbia, Oregon, and Mexico, east to Atlantic Ocean.

At the top of a gradually lengthened and apparently overburdened leafy stalk, weakly leaning upon surrounding vegetation, a few perfect blossoms spread their violet wheels, while below them are insignificant earlier flowers, which, although they have never opened, nor reared their heads above the hollows of the little shell-like leaves where they lie secluded, have, nevertheless, been producing seed without imported pollen while their showy sisters slept. But the later blooms, by attracting insects, set cross-fertilized seed to counteract any evil tendencies that might weaken the species if it depended upon self-fertilization only. When the European Venus' Looking-glass used to be cultivated in gardens here, our grandmothers tell us it was altogether too prolific, crowding out of existence its less fruitful, but more lovely, neighbors. 


\section{LOBELIA FAMILY (Lobeliaceae)}

\section{Cardinal Flower; Red Lobelia}

Lobelia cardinalis

Flowers-Rich vermilion, very rarely rose or white, 1 to $1-1 / 2$ in. long, numerous, growing in terminal, erect, green-bracted, more or less 1-sided racemes. Calyx 5-cleft; corolla tubular, split down one side, 2-lipped; the lower lip with 3 spreading lobes, the upper lip 2-lobed, erect; 5 stamens united into a tube around the style; 2 anthers with hairy tufts. Stem: 2 to $4-1 / 2 \mathrm{ft}$. high, rarely branched. Leaves: Oblong to lance-shaped, slightly toothed, mostly sessile.

Preferred Habitat - Wet or low ground, beside streams, ditches, and meadow runnels.

Flowering Season-July-September.

Distribution-New Brunswick to the Gulf states, westward to the Northwest Territory and Kansas.

The easy cultivation from seed of this peerless wild flower-and it is offered in many trade catalogues-might save it to those regions in Nature's wide garden that now know it no more. The ranks of floral missionaries need recruits.

Curious that the great Blue Lobelia should be the cardinal flower's twin sister! Why this difference of color? Sir John Lubbock proved by tireless experiment that the bees' favorite color is blue, and the shorter-tubed Blue Lobelia elected to woo them as her benefactors. Whoever has made a study of the ruby-throated hum- 
ming bird's habits must have noticed how red flowers entice him-columbines, painted cups, coral honeysuckle, Oswego Tea, trumpet flower, and cardinal in Nature's garden; cannas, salvia, gladioli, pelargoniums, fuchsias, phloxes, verbenas, and nasturtiums among others in ours.

Great Lobelia; Blue Cardinal Flower

\section{Lobelia syphilitica}

Flowers - Bright blue, touched with white, fading to pale blue, about 1 in. long, borne on tall, erect, leafy spike. Calyx 5-parted, the lobes sharply cut, hairy. Corolla tubular, open to base on one side, 2 -lipped, irregularly 5 -lobed, the petals pronounced at maturity only. Stamens 5 , united by their hairy anthers into a tube around the style; larger anthers smooth. Stem: 1 to $3 \mathrm{ft}$. high, stout, simple, leafy, slightly hairy. Leaves: Alternate, oblong, tapering, pointed, irregularly toothed 2 to $6 \mathrm{in}$. long, $1 / 2$ to $2 \mathrm{in}$. wide.

Preferred Habitat-Moist or wet soil; beside streams.

Flowering Season-July-October.

Distribution-Ontario and northern United States west to Dakota, south to Kansas and Georgia.

To the evolutionist, ever on the lookout for connecting links, the lobelias form an interesting group, because their corolla, slit down the upper side and somewhat flattened, shows the beginning of the tendency toward the strap or ray flowers that are nearly confined to the composites of much later development, of course, than tubular single blossoms. Next to massing their flowers in showy heads, as the composites do, the lobelias have the almost equally advantageous plan of crowding theirs along a stem so as to make a conspicuous advertisement to attract the passing bee and to offer him the special inducement of numerous feeding places close together.

The handsome Great Lobelia, constantly and invidiously compared with its gorgeous sister the cardinal flower, suffers unfairly. When asked what his favorite color was, Eugene Field replied: "Why, I like any color at all so long as it's red!" Most men, at least, agree with him, and certainly humming birds do; our scarcity of red flowers being due, we must believe, to the scarcity of humming birds, which chiefly fertilize them. But how bees love the blue blossoms!

Linnaeus named this group of plants for Matthias de l'Obel, a Flemish botanist, or herbalist more likely, who became physician to James I of England. 


\section{COMPOSITE FAMILY (Compositae)}

Iron-weed; Flat Top

Vernonia noveboracensis

Flower-head-Composite of tubular florets only, intense reddish-purple thistlelike heads, borne on short, branched peduncles and forming broad, flat clusters; bracts of involucre, brownish purple, tipped with awl-shaped bristles. Stem: 3 to $9 \mathrm{ft}$. high, rough or hairy, branched. Leaves: Alternate, narrowly oblong or lanceolate, saw-edged, 3 to $10 \mathrm{in}$. long, rough.

Preferred Habitat-Moist soil, meadows, fields.

Flowering Season-July-September.

Distribution-Massachusetts to Georgia, and westward to the Mississippi.

Emerson says a weed is a plant whose virtues we have not yet discovered; but surely it is no small virtue in the iron-weed to brighten the roadsides and low meadows throughout the summer with bright clusters of bloom. When it is on the wane, the asters, for which it is sometimes mistaken, begin to appear, but an instant's comparison shows the difference between the two flowers. After noting the yellow disk in the centre of an aster, it is not likely the iron-weed's thistle-like head of ray florets only will ever again be confused with it. Another rank-growing neighbor with which it has been comfounded by the novice is the Joe-Pye Weed, a far paler, old-rose colored flower, as one who does not meet them both afield may see on comparing the colored plates in this book. 
Joe-Pye Weed; Trumpet Weed; Purple Thoroughwort; Gravel or Kidney-root; Tall or Purple Boneset

\section{Eupatorium purpureum}

Flower-heads-Pale or dull magenta or lavender pink, slightly fragrant, of tubular florets only, very numerous, in large, terminal, loose, compound clusters, generally elongated. Several series of pink overlapping bracts form the oblong involucre from which the tubular floret and its protruding fringe of style-branches arise. Stem: 3 to $10 \mathrm{ft}$. high, green or purplish, leafy, usually branching toward top. Leaves: In whorls of 3 to 6 (usually 4), oval to lance-shaped, saw-edged, petioled, thin, rough.

Preferred Habitat-Moist soil, meadows, woods, low ground.

Flowering Season-August-September.

Distribution-New Brunswick to the Gulf of Mexico, westward to Manitoba and Texas.

Towering above the surrounding vegetation of low-lying meadows, this vigorous composite spreads clusters of soft, fringy bloom that, however deep or pale of tint, are ever conspicuous advertisements, even when the golden-rods, sunflowers, and asters enter into close competition for insect trade. Slight fragrance, which to the delicate perception of butterflies is doubtless heavy enough, the florets' color and slender tubular form indicate an adaptation to them, and they are by far the most abundant visitors, which is not to say that long-tongued bees and flies never reach the nectar and transfer pollen, for they do. But an excellent place for the butterfly collector to carry his net is to a patch of Joe-Pye Weed in September. As the spreading style-branches that fringe each tiny floret are furnished with hairs for three quarters of their length, the pollen caught in them comes in contact with the alighting visitor. Later, the lower portion of the style-branches, that is covered with stigmatic papillae along the edge, emerges from the tube to receive pollen carried from younger flowers when the visitor sips his reward. If the hairs still contain pollen when the stigmatic part of the style is exposed, insects self-fertilize the flower; and if in stormy weather no insects are flying, the flower is nevertheless able to fertilize itself, because the hairy fringe must often come in contact with the stigmas of neighboring florets. It is only when we study flowers with reference to their motives and methods that we understand why one is abundant and another rare. Composites long ago utilized many principles of success in life that the triumphant Anglo-Saxon carries into larger affairs to-day. 
Joe-Pye, an Indian medicine-man of New England, earned fame and fortune by curing typhus fever and other horrors with decoctions made from this plant.

Boneset; Common Thorough wort; Agueweed; Indian Sage

Eupatorium perfoliatum

Flower-heads-Composite, the numerous, small, dull, white heads of tubular florets only, crowded in a scaly involucre and borne in spreading, flat-topped terminal cymes. Stem: Stout, tall, branching above, hairy, leafy. Leaves: Opposite, often united at their bases, or clasping, lance-shaped, saw-edged, wrinkled.

Preferred Habitat - Wet ground, low meadows, roadsides.

Flowering Season-July-September.

Distribution-From the Gulf states north to Nebraska, Manitoba, and New Brunswick.

Frequently, in just such situations as its sister the Joe-Pye Weed selects, and with similar intent, the boneset spreads its soft, leaden-white bloom; but it will be noticed that the butterflies, which love color, especially deep pinks and magenta, let this plant alone, whereas beetles, that do not find the butterfly's favorite, fragrant Joe-Pye Weed at all to their liking, prefer these dull, odorous flowers. Many flies, wasps, and bees also, get generous entertainment in these tiny florets, where they feast with the minimum loss of time, each head in a cluster containing, as it does, from ten to sixteen restaurants. An ant crawling up the stem is usually discouraged by its hairs long before reaching the sweets. Sometimes the stem appears to run through the centre of one large leaf that is kinky in the middle and taperpointed at both ends, rather than between a pair of leaves.

An old-fashioned illness known as break-bone fever-doubtless paralleled to-day by the grippe-once had its terrors for a patient increased a hundredfold by the certainty he felt of taking nauseous doses of boneset tea, administered by zealous old women outside the "regular practice." Children who had to have their noses held before they would—or, indeed, could—swallow the decoction, cheerfully munched boneset taffy instead.

Golden-rods 


\section{Solidago}

When these flowers transform whole acres into "fields of the cloth-of-gold," the slender wands swaying by every roadside, and Purple Asters add the final touch of imperial splendor to the autumn landscape, already glorious with gold and crimson, is any parterre of Nature's garden the world around more gorgeous than that portion of it we are pleased to call ours? Within its limits eighty-five species of golden-rod flourish, while a few have strayed into Mexico and South America, and only two or three belong to Europe, where many of ours are tenderly cultivated in gardens, as they would be here, had not Nature been so lavish. To name all these species, or the asters, the sparrows, and the warblers at sight is a feat probably no one living can perform; nevertheless, certain of the commoner goldenrods have well-defined peculiarities that a little field practice soon fixes in the novice's mind.

Along shady roadsides, and in moist woods and thickets, from August to October, the Blue-stemmed, Wreath, or Woodland Golden-rod (S. caesia) sways an unbranched stem with a bluish bloom on it. It is studded with pale golden clusters of tiny florets in the axils of lance-shaped, feather-veined leaves for nearly its entire length. Range from Maine, Ontario, and Minnesota to the Gulf states. None is prettier, more dainty, than this common species.

In rich woodlands and thicket borders we find the Zig-zag or Broad-leaved Golden-rod (S. latifolia) - its prolonged, angled stem that grows as if waveringly uncertain of the proper direction to take, strung with small clusters of yellow florets, somewhat after the manner of the preceding species. But its saw-edged leaves are ovate, sharply tapering to a point, and narrowed at the base into petioles. It blooms from July to September. Range from New Brunswick to Georgia, and westward beyond the Mississippi.

During the same blooming period, and through a similar range, our only albino, with an Irish-bull name, the White Golden-rod, or more properly Silver-rod (S. bicolor), cannot be mistaken. Its cream-white florets also grow in little clusters from the upper axils of a usually simple and hairy gray stem six inches to four feet high. Most of the heads are crowded in a narrow, terminal pyramidal cluster. This plant approaches more nearly the idea of a rod than its relatives. The leaves, which are broadly oblong toward the base of the stem, and narrowed into long margined petioles, are frequently quite hairy, for the silver-rod elects to live in dry soil and its juices must be protected from heat and too rapid transpiration. 
When crushed in the hand, the dotted, bright green, lance-shaped, entire leaves of the Sweet Golden-rod or Blue Mountain Tea (S. odora) cannot be mistaken, for they give forth a pleasant anise scent. The slender, simple smooth stem is crowned with a graceful panicle, whose branches have the florets seated all on one side. Dry soil. New England to the Gulf states. July to September.

The Wrinkle-leaved, or Tall, Hairy Golden-rod or Bitterweed (S. rugosa), a perversely variable species, its hairy stem perhaps only a foot high, or, maybe, more than seven feet, its rough leaves broadly oval to lance-shaped, sharply saw-edged, few if any furnished with footstems, lifts a large, compound, and gracefully curved panicle, whose florets are seated on one side of its spreading branches. Sometimes the stem branches at the summit. One usually finds it blooming in dry soil from July to November throughout a range extending from Newfoundland and Ontario to the Gulf states.

The unusually beautiful, spreading, recurved, branching panicle of bloom borne by the early, Plume, or Sharp-toothed Golden-rod or Yellow-top (S. juncea), so often dried for winter decoration, may wave four feet high but, lisually not more than two, at the summit of a smooth, rigid stem. Toward the top, narrow, elliptical, uncut leaves are seated on the stalk; below, much larger leaves, their sharp teeth slanting forward, taper into a broad petiole, whose edges may be cut like fringe. In dry, rocky soil this is, perhaps, the first and last golden-rod to bloom, having been found as early as June, and sometimes lasting into November. Range from North Carolina and Missouri very far north.

Perhaps the commonest of all the lovely clan east of the Mississippi, or throughout a range extending from Arizona and Florida northward to British Columbia and New Brunswick, is the Canada Golden-rod or Yellow-weed (S. canadensis). Surely every one must be familiar with the large, spreading, dense-flowered panicle, with recurved sprays, that crowns a rough, hairy stem sometimes eight feet tall, or again only two feet. Its lance-shaped, acutely pointed, triple-nerved leaves are rough, and the lower ones saw-edged. From August to November one cannot fail to find it blooming in dry soil.

Most brilliantly colored of its tribe is the low-growing Gray or Field Golden-rod or Dyer's Weed (S. nemoralis). The rich, deep yellow of its little spreading recurved, and usually one-sided panicles is admirably set off by the ashy gray, or often cottony, stem, and the hoary, grayish-green leaves in the open, sterile places where they arise from July to November. Quebec and the Northwest Territory to the Gulf states. 


\section{"Along the roadside, like the flowers of gold That tawny Incas for their gardens wrought, Heavy with sunshine droops the golden-rod.'}

Bewildered by the multitude of species, and wondering at the enormous number of representatives of many of them, we cannot but inquire into the cause of such triumphal conquest of a continent by a single genus. Much is explained simply in the statement that golden-rods belong to the vast order of Compositae, flowers in reality made up sometimes of hundreds of minute florets united into a faradvanced socialistic community having for its motto, "In union there is strength." In the first place, such an association of florets makes a far more conspicuous advertisement than a single flower, one that can be seen by insects at a great distance; for most of the composite plants live in large colonies, each plant, as well as each floret, helping the others in attracting their benefactors' attention. The facility with which insects are enabled to collect both pollen and nectar makes the golden-rods exceedingly popular restaurants. Finally, the visits of insects are more likely to prove effectual, because any one that alights must touch several or many florets, and cross-pollinate them simply by crawling over a head. The disk florets mostly contain both stamens and pistil, while the ray florets in one series are all male. Immense numbers of wasps, hornets, bees, flies, beetles, and "bugs" feast without effort here: indeed, the budding entomologist might form a large collection of Hymenoptera, Diptera, Coleoptera, and Hemiptera from among the visitors to a single freld of golden-rod alone. Usually to be discovered among the throng are the velvety black Lytta or Cantharis, that impostor wasp-beetle, the black and yellow wavy-banded, red-legged locust-tree borer, and the painted Clytus, banded with yellow and sable, squeaking contentedly as he gnaws the florets that feed him.

Where the slender, brown, plume-tipped wands etch their charming outline above the snow-covered frelds, how the sparrows, finches, buntings, and juncos love to congregate, of course helping to scatter the seeds to the wind while satisfying their hunger on the swaying, down-curved stalks. Now that the leaves are gone, some of the golden-rod stems are seen to bulge as if a tiny ball were concealed under the bark. In spring a little winged tenant, a fly, will emerge from the gall that has been his cradle all winter.

Blue and Purple Asters or Starworts

Aster

Evolution teaches us that thistles, daisies, sunflowers, asters, and all the triumphant horde of composites were once very different flowers from what we see 
to-day. Through ages of natural selection of the fittest among their ancestral types, having finally arrived at the most successful adaptation of their various parts to their surroundings in the whole floral kingdom, they are now overrunning the earth. Doubtless the aster's remote ancestors were simple green leaves around the vital organs, and depended upon the wind, as the grasses do-a most extravagant method-to transfer their pollen. Then some rudimentary flower changed its outer row of stamens into petals, which gradually took on color to attract insects and insure a more economical method of transfer. Gardeners to-day take advantage of a blossom's natural tendency to change stamens into petals when they wish to produce double flowers. As flowers and insects developed side by side, and there came to be a better and better understanding between them of each other's requirements, mutual adaptation followed. The flower that offered the best advertisement, as the composites do, by its showy rays; that secreted nectar in tubular flowers where no useless insect could pilfer it; that fastened its stamens to the inside wall of the tube where they must dust with pollen the underside of every insect, unwittingly cross-fertilizing the blossom as he crawled over it; that massed a great number of these tubular florets together where insects might readily discover them and feast with the least possible loss of time-this flcwer became the winner in life's race. Small wonder that our June fields are white with daisies and the autumn landscape is glorified with golden-rod and asters!

Since North America boasts the greater part of the two hundred and fifty asters named by scientists, and as variations in many of our common species frequently occur, the tyro need expect no easy task in identifying every one he meets afield. However, the following are possible acquaintances to every one:

In dry, shady places the Large, or Broad-leaved Aster (A. macrophyllus), so called from its three or four conspicuous, heart-shaped leaves on long petioles, in a clump next the ground, may be more easily identified by these than by the pale lavender or violet flower-heads of about sixteen rays each which crown its reddish angular stem in August and September. The disk turns reddish brown.

Much more branched and bushy is the Common Blue, Branching, Wood, or Heart-leaved Aster (A. cordifolius), whose generous masses of small, pale lavender flower-heads look like a mist hanging from one to five feet above the earth in and about the woods and shady roadsides from September even to December in favored places.

By no means tardy, the Late Purple Aster, so-called, or Purple Daisy (A. patens), begins to display its purplish-blue, daisy-like flower-heads early in August, and farther north may be found in dry, exposed places only until October. Rarely the 
solitary flowers, that are an inch across or more, are a deep, rich violet. The twenty to thirty rays which surround the disk, curling inward to dry, expose the vaseshaped, green, shingled cups that terminate each little branch. The thick, somewhat rigid, oblong leaves, tapering at the tip, broaden at the base to clasp the rough, slender stalk. Range similar to the next species.

Certainly from Massachusetts, northern New York, and Minnesota southward to the Gulf of Mexico one may expect to find the New England Aster or Starwort (A. novae-angliae), one of the most striking and widely distributed of the tribe, in spite of its local name. It is not unknown in Canada. The branching clusters of violet or magenta-purple flower-heads, from one to two inches across-composites containing as many as forty to fifty purple ray florets around a multitude of perfect five-lobed, tubular, yellow disk florets in a sticky cup-shine out with royal splendor above the swamps, moist fields, and roadsides from August to October. The stout, bristle-hairy stem bears a quantity of alternate lance-shaped leaves lobed at the base where they clasp it.

In even wetter ground we find the Red-stalked, Purple-stemmed, or Early Purple Aster, Cocash, Swanweed, or Meadow Scabish (A. puniceus) blooming as early as July or as late as November. Its stout, rigid stem, bristling with rigid hairs, may reach a height of eight feet to display the branching clusters of pale violet or lavender flowers. The long, blade-like leaves, usually very rough above and hairy along the midrib beneath, are seated on the stem.

The lovely Smooth or Blue Aster (A. laevis), whose sky-blue or violet flowerheads, about one inch broad, are common through September and October in dry soil and open woods, has strongly clasping, oblong, tapering leaves, rough margined, but rarely with a saw-tooth, toward the top of the stem, while those low down on it gradually narrow into clasping wings.

In dry, sandy soil, mostly near the coast, from Massachusetts to Delaware, grows one of the loveliest of all this beautiful clan, the Low, Showy, or Seaside Purple Aster (A. spectabilis). The stiff, usually unbranched stem does its best in attaining a height of two feet. Above, the leaves are blade-like or narrowly oblong, seated on the stem, whereas the tapering, oval basal leaves are furnished with long footstems, as is customary with most asters. The handsome, bright, violet-purple flower-heads, measuring about an inch and a half across, have from fifteen to thirty rays, or only about half as many as the familiar New England aster. Season: August to November. 
In dry, open woodlands, thickets, and roadsides, from August to October, we find the dainty White Wood Aster (A. divaricatus) - A. corymbosus of Gray-its britthe zig-zag stem two feet high or less, branching at the top, and repeatedly forked where loose clusters of flower-heads spread in a broad, rather flat corymb. Only a few white rays-usually from six to nine-surround the yellow disk, whose florets soon turn brown. Range from Canada southward to Tennessee.

The bushy little White Heath Aster (A. ericoides) every one must know, possibly, as Michaelmas Daisy, Farewell Summer, White Rosemary, or Frost-weed; for none is commoner in dry soil, throughout the eastern United States at least. Its smooth, much-branched stem rarely reaches three feet in height, usually it is not more than a foot tall, and its very numerous flower-heads, white or pink tinged, barely half an inch across, appear in such profusion from September even to December as to transform it into a feathery mass of bloom.

Growing like branching wands of golden-rod, the Dense-flowered, Whitewreathed, or Starry Aster (A. multiflorus) bears its minute flower-heads crowded close along the branches, where many small, stiff leaves, like miniature pine needles, follow them. Each flower measures only about a quarter of an inch across. From Maine to Georgia and Texas westward to Arizona and British Columbia the common bushy plant lifts its rather erect, curving, feathery branches perhaps only a foot, sometimes above a man's head, from August till November, in such dry, open, sterile ground as the white Heath Aster also chooses.

\section{Golden Aster}

\section{Chrysopsis mariana}

Flower-heads-Composite, yellow, 1 in. wide or less, a few corymbed flowers on glandular stalks; each composed of perfect tubular disk florets surrounded by pistillate ray florets; the involucre campanulate, its narrow bracts overlapping in several series. Stem: Stout, silky, hairy when young, nearly smooth later, 1 to 2-1/2 ft. tall. Leaves: Alternate, oblong to spatulate, entire.

Preferred Habitat-Dry soil, or sandy, not far inland.

Flowering Season-August-September.

Distribution-Long Island and Pennsylvania to the Gulf states. 
Whoever comes upon clumps of these handsome flowers by the dusty roadside cannot but be impressed with the appropriateness of their generic name (Chrysos = gold; opsis = aspect). Farther westward, north and south, it is the Hairy Golden Aster (C. villosa), a pale, hoary-haired plant with similar flowers borne at midsummer, that is the common species.

\section{Daisy Fleabane; Sweet Scabious}

\section{Erigeron annuus}

Flower-heads-Numerous, daisy-like, about $1 / 2$ in. across; from 40 to 70 long, fine, white rays (or purple or pink tinged), arranged around yellow disk florets in a rough, hemispheric cup whose bracts overlap. Stem: Erect, 1 to $4 \mathrm{ft}$. high, branching above, with spreading, rough hairs. Leaves: Thin, lower ones ovate, coarsely toothed, petioled; upper ones sessile, becoming smaller, lance-shaped.

Preferred Habitat-Fields, waste land, roadsides.

Flowering Season-May-November.

Distribution-Nova Scotia to Virginia, westward to Missouri.

At a glance one knows this flower to be akin to Robin's plantain, the asters and daisy. A smaller, more delicate species, with mostly entire leaves and appressed hairs (E. ramosus) - E. strigosum of Gray-has a similar range and season of bloom. Both soon grow hoary-headed after they have been fertilized by countless insects crawling over them (Erigeron = early old). That either of these plants, or the pinkish, small-flowered, strong-scented Salt-marsh Fleabane (Pluchea camphorata), drive away fleas, is believed only by those who have not used them dried, reduced to powder, and sprinkled in kennels, from which, however, they have been known to drive away dogs.

Robin's, or Poor Robin's, or Robert's Plantain; Blue Spring Daisy; Daisy-leaved Fleabane

Erigeron pulchellus

Flower-heads-Composite, daisy-like, 1 to $1-1 / 2$ in. across; the outer circle of about 50 pale bluish-violet ray florets; the disk florets greenish yellow. Stem: Simple, erect, hairy, juicy, flexible, from $10 \mathrm{in}$. to $2 \mathrm{ft}$. high, producing runners and offsets from base. Leaves: Spatulate, in a flat tuft about the root; stem leaves narrow, more acute, seated, or partly clasping. 
Preferred Habitat—Moist ground, hills, banks, grassy fields.

Flowering Season-April-June.

Distribution-United States and Canada, east of the Mississippi.

Like an aster blooming long before its season, Robin's Plantain wears a finely cut lavender fringe around a yellow disk of minute florets; but one of the first, not the last, in the long procession of composites has appeared when we see gay companies of these flowers nodding their heads above the grass in the spring breezes as if they were village gossips.

Pearly, or Large-flowered, Everlasting; Immortelle, Silver Leaf; Moonshine; Cottonweed; None-so-pretty

Anaphalis margaritacea

Flower-heads-Numerous pearly-white scales of the involucre holding tubular florets only; borne in broad, rather flat, compound corymbs at the summit. Stem: Cottony, 1 to $3 \mathrm{ft}$. high, leafy to the top. Leaves: Upper ones small, narrow, linear; lower ones broader, lance-shaped, rolled backward, more or less woolly beneath.

Preferred Habitat—Dry fields, hillsides, open woods, uplands.

Flowering Season—July-September.

Distribution—North Carolina, Kansas, and California, far north.

When the small, white, overlapping scales of an everlasting's oblong involucre expand stiff and straight, each pert little flower-head resembles nothing so much as a miniature pond lily, only what would be a lily's yellow stamens are in this case the true flowers, which become brown in drying. It will be noticed that these tiny florets, so well protected in the centre, are of two different kinds, separated on distinct heads: the female florets with a tubular, five-cleft corolla, a two-cleft style, and a copious pappus of hairy bristles; the staminate, or male, florets more slender, the anthers tailed at the base. Self-fertilization being, of course, impossible under such an arrangement, the florets are absolutely dependent upon little winged pollen carriers, whose sweet reward is well protected for them from pilfering ants by the cottony substance on the wiry stem, a device successfully employed by thistles also. 
An imaginary blossom that never fades has been the dream of poets from Milton's day; but seeing one, who loves it? Our amaranth has the aspect of an artificial flower-stiff, dry, soulless, quite in keeping with the decorations on the average farmhouse mantelpiece. Here it forms the most uncheering of winter bouquets, or a wreath about flowers made from the lifeless hair of some dear departed.

\section{Elecampane; Horseheal; Yellow Starwort}

\section{Inula Helenium}

Flower-heads - Large, yellow, solitary or a few, 2 to $4 \mathrm{in}$. across, on long, stout peduncles; the scaly green involucre nearly $1 \mathrm{in}$. high, holding disk florets surrounded by a fringe of long, very narrow, 3-toothed ray florets. Stem: Usually unbranched, 2 to $6 \mathrm{ft}$. high, hairy above. Leaves: Alternate, large, broadly oblong, pointed, saw-edged, rough above, woolly beneath; some with heart-shaped, clasping bases.

Preferred Habitat-Roadsides, fields, fence-rows, damp pastures.

Flowering Season-July-September.

Distribution-Nova Scotia to the Carolinas, and westward to Minnesota and Missouri.

The elecampane has not always led a vagabond existence. Once it had its passage paid across the Atlantic, because special virtue was attributed to its thick, mucilaginous roots as a horse medicine. For more than two thousand years it has been employed by home doctors in Europe and Asia; and at first Old World immigrants thought they could not live here without the plant on their farms. Once given a chance to naturalize itself, no composite is slow in seizing it. The vigorous elecampane, rearing its fringy, yellow disks above lichen-covered stone walls in New England, the Virginia rail fence, and the rank weedy growth along barbed-wire barriers farther west, now bids fair to cross the continent.

Black-eyed Susan; Yellow or Ox-eye Daisy; Nigger-head; Golden Jerusalem; Purple Cone-flower

Rudbeckia hirta 
Flower-heads-From 10 to 20 orange-yellow neutral rays around a conical, dark purplish-brown disk of florets containing both stamens and pistil. Stem: 1 to $3 \mathrm{ft}$. tall, hairy, rough, usually unbranched, often tufted. Leaves: Oblong to lanceshaped, thick, sparingly notched, rough.

Preferred Habitat-Open sunny places; dry fields.

Flowering Season-May-September.

Distribution-Ontario and the Northwest Territory south to Colorado and the Gulf states.

So very many weeds having come to our Eastern shores from Europe, and marched farther and farther west year by year, it is but fair that black-eyed Susan, a native of Western clover fields, should travel toward the Atlantic in bundles of hay whenever she gets the chance, to repay Eastern farmers in their own coin. Do these gorgeous heads know that all our showy rudbeckias — some with orange red at the base of their ray florets-have become prime favorites of late years in European gardens, so offering them still another chance to overrun the Old World, to which so much American hay is shipped? Thrifty farmers may decry the importation into their mowing lots, but there is a glory to the cone-flower beside which the glitter of a gold coin fades into paltry nothingness. Having been instructed in the decorative usefulness of all this genus by European landscape gardeners, we Americans now importune the Department of Agriculture for seeds through members of Congress, even Representatives of States that have passed stringent laws against the dissemination of "weeds." Inasmuch as each black-eyed Susan puts into daily operation the business methods of the white daisy, methods which have become a sort of creed for the entire composite horde to live by, it is plain that she may defy both farmers and legislators. Bees, wasps, flies butterflies, and beetles could not be kept away from an entertainer so generous; for while the nectar in the deep, tubular brown florets may be drained only by long, slender tongues, pollen is accessible to all. Any one who has had a jar of these yellow daisies standing on a polished table indoors, and tried to keep its surface free from a ring of golden dust around the flowers, knows how abundant their pollen is. The black-eyed Susan, like the English sparrow, has come to stay-let farmers and law-makers do what they will.

Tall or Giant Sunflower

Helianthus giganteus 
Flower-heads-Several, on long, rough-hairy peduncles; $1-1 / 2$ to 2-1/4 in. broad; 10 to 20 pale yellow neutral rays around a yellowish disk whose florets are perfect, fertile. Stem: 3 to $12 \mathrm{ft}$. tall, bristly-hairy, usually branching above, often reddish; from a perennial, fleshy root. Leaves: Rough, firm, lance-shaped, sawtoothed, sessile.

Preferred Habitat-Low ground, wet meadows, swamps.

Flowering Season-August-October.

Distribution-Maine to Nebraska and the Northwest Territory, south to the Gulf of Mexico.

To how many sun-shaped golden disks with outflashing rays might not the generic name of this clan (helios = the sun, anthos = a flower) be as fittingly applied: from midsummer till frost the earth seems given up to floral counterparts of his worshipful majesty. If, as we are told, one ninth of all flowering plants in the world belong to the composite order, of which more than sixteen hundred species are found in North America north of Mexico, surely more than half this number are made up after the daisy pattern, the most successful arrangement known, and the majority of these are wholly or partly yellow. Most conspicuous of the horde are the sunflowers, albeit they never reach in the wild state the gigantic dimensions and weight that cultivated, dark-brown centred varieties produced from the common sunflower have attained. For many years the origin of the latter flower, which suddenly shone forth in European gardens with unwonted splendor, was in doubt. Only lately it was learned that when Champlain and Segur visited the Indians on Lake Huron's eastern shores about three centuries ago, they saw them cultivating this plant, which must have been brought by them from its native prairies beyond the Mississippi-a plant whose stalks furnished them with a textile fibre, its leaves fodder, its flowers a yellow dye, and its seeds, most valuable of all, food and hair-oil! Early settlers in Canada were not slow in sending home to Europe so decorative and useful an acquisition. Swine, poultry, and parrots were fed on its rich seeds. Its flowers, even under Indian cultivation, had already reached abnormal size. Of the sixty varied and interesting species of wild sunflowers known to scientists, all are North American.

Moore's pretty statement,

"As the sunflower turns on her god when he sets The same look which she turn'd when he rose," 
lacks only truth to make it fact. The flower does not travel daily on its stalk from east to west. Often the top of the stem turns sharply toward the light to give the leaves better exposure, but the presence or absence of a terminal flower affects its action not at all.

Sneeze weed; Swamp Sunflower

Helenium autumnale

Flower-heads-Bright yellow, 1 to 2 in. across, numerous, borne on long peduncles in corymb-like clusters; the rays 3 to $5 \mathrm{cleft}$, and drooping around the yellow or yellowish-brown disk. Stem: 2 to $6 \mathrm{ft}$. tall, branched above. Leaves: Alternate, firm, lance-shaped to oblong, toothed, seated on stem or the bases slightly decurrent; bitter.

Preferred Habitat-Swamps, wet ground, banks of streams.

Flowering Season-August-October. Distribution-Quebec to the Northwest Territory; southward to Florida and Arizona.

Most cows know enough to respect the bitter leaves' desire to be let alone; but many a pail of milk has been spoiled by a mouthful of Helenium among the herbage. Whoever cares to learn from experience why this was called sneezeweed, must take a whiff of snuff made of the dried and powdered leaves.

Yarrow; Milfoil; Old Man’s Pepper; Nosebleed

\section{Achillea Millefolium}

Flower-heads-Grayish-white, rarely pinkish, in a hard, close, flat-topped, compound cluster. Ray florets 4 to 6 , pistillate, fertile; disk florets yellow, afterward brown, perfect, fertile. Stem: Erect, from horizontal root-stalk, 1 to $2 \mathrm{ft}$. high, leafy, sometimes hairy. Leaves: Very finely dissected (Millefolium = thousand leaf), narrowly oblong in outline.

Preferred Habitat-Waste land, dry fields, banks, roadsides.

Flowering Season-June-November.

Distribution-Naturalized from Europe and Asia throughout North America. 
Everywhere this commonest of common weeds confronts us; the compact, dustylooking clusters appearing not by waysides only, around the world, but in the mythology, folk-lore, medicine, and literature of many peoples. Chiron, the centaur, who taught its virtues to Achilles that he might make an ointment to heal his Myrmidons wounded in the siege of Troy, named the plant for this favorite pupil, giving his own to the beautiful Blue Cornflower (Centaurea Cyanus). As a love-charm; as an herb-tea brewed by crones to cure divers ailments, from loss of hair to the ague; as an inducement to nosebleed for the relief of congestive headache; as an ingredient of an especially intoxicating beer made by the Swedes, it is mentioned in old books. Nowadays we are satisfied merely to admire the feathery masses of lace-like foliage formed by young plants, to whiff the wholesome, nutty, autumnal odor of its flowers, or to wonder at the marvellous scheme it employs to overrun the earth.

Dog's or Foetid Camomile: Mayweed; Pig-sty Daisy; Dillweed; Dog-fennel

\section{Anthemis Cotula (Maruta Cotula)}

Flower-heads-Like smaller daisies, about 1 in. broad; 10 to 18 white, notched, neutral ray florets around a convex or conical yellow disk, whose florets are fertile, containing both stamens and pistil, their tubular corollas 5-cleft. Stem: Smooth, much branched, 1 to $2 \mathrm{ft}$. high, leafy, with unpleasant odor and acrid taste. Leaves: Very finely dissected into slender segments.

Preferred Habitat--Roadsides, dry waste land, sandy fields.

Flowering Season-June-November.

Distribution-Throughout North America, except in circumpolar regions.

"Naturalized from Europe, and widely distributed as a weed in Asia, Africa, and Australasia" (Britton and Brown's "Flora"). Little wonder the camomile encompasses the earth, for it imitates the triumphant daisy, putting into practice those business methods of the modern department store, by which the composite horde have become the most successful strugglers for survival.

Dog, used as a prefix by several of the plant's folk-names, implies contempt for its worthlessness. It is quite another species, the Garden Camomile (A. nobilis), which furnishes the apothecary with those flowers which, when steeped into a bitter, aromatic tea, have been supposed for generations to make a superior tonic and blood purifier. 
Common Daisy; White-weed; White or Ox-eye Daisy; Marguerite; Love-me, Love-me-not

Chrysanthemum Leucanthemum

Flower-heads-Disk florets yellow, tubular, 4 or 5 toothed, containing stamens and pistil; surrounded by white ray florets, which are pistillate, fertile. Stem: Smooth, rarely branched, 1 to $3 \mathrm{ft}$. high. Leaves: Mostly oblong in outline, coarsely toothed and divided.

Preferred Habitat-Meadows, pastures, roadsides, waste land.

Flowering Season-May-November.

Distribution-Throughout the United States and Canada; not so common in the South and West.

Myriads and myriads of daisies, whitening our fields as if a belated blizzard had covered them with a snowy mantle in June, fill the farmer with dismay, the flower-lover with rapture. When vacation days have come; when chains and white-capped old women are to be made of daisies by happy children turned out of schoolrooms into meadows; when pretty maids, like Goethe's Marguerite, tell their fortunes by the daisy "petals"; when music bubbles up in a cascade of ecstasy from the throats of bobolinks nesting among the daisies, timothy, and clover; when the blue sky arches over the fairest scenes the year can show, and all the world is full of sunshine and happy promises of fruition, must we Americans always go to English literature for a song to fit our joyous mood?

"When daisies pied, and violets blue, And lady-smocks all silver white,

And cuckoo-buds of yellow hue,

Do paint the meadows with delight-"

sang Shakespeare. His lovely suggestion of an English spring recalls no familiar picture to American minds. No more does Burns's.

"Wee, modest, crimson-tippit flower."

Shakespeare, Burns, Chaucer, Wordsworth, and all the British poets who have written familiar lines about the daisy, extolled a quite different flower from ours- 
Bellis perennis, the little pink and white blossom that hugs English turf as if it loved it - the true day's-eye, for it closes at nightfall and opens with the dawn.

Now, what is the secret of the large, white daisy's triumphal conquest of our territory? A naturalized immigrant from Europe and Asia, how could it so quickly take possession? In the over-cultivated Old World no weed can have half the chance for unrestricted colonizing that it has in our vast, unoccupied area. Most of our weeds are naturalized foreigners, not natives. Once released from the harder conditions of struggle at home (the seeds bring safely smuggled in among the ballast of freight ships, or hay used in packing), they find life here easy, pleasant; as if to make up for lost time, they increase a thousandfold. If we look closely at a daisy - and a lens is necessary for any but the most superficial acquaintancewe shall see that, far from being a single flower, it is literally a host in itself. Each of the so-called white "petals" is a female floret, whose open corolla has grown large, white, and showy, to aid its sisters in advertising for insect visitors-a prominence gained only by the loss of its stamens. The yellow centre is composed of hundreds of minute tubular florets huddled together in a green cup as closely as they can be packed. Inside each of these tiny yellow tubes stand the stamens, literally putting their heads together. As the pistil within the ring of stamens develops and rises through their midst, two little hair brushes on its tip sweep the pollen from their anthers as a rounded brush would remove the soot from a lamp chimney. Now the pollen is elevated to a point where any insect crawling over the floret must remove it. The pollen gone, the pistil now spreads its two arms, that were kept tightly closed together while any danger of self-fertilization lasted. Their surfaces become sticky, that pollen brought from another flower may adhere to them. Notice that the pistils in the white ray florets have no hair brushes on their tips, because, no stamens being there, there is no pollen to be swept out. Because daisies are among the most conspicuous of flowers, and have facilitated dining for their visitors by offering them countless cups of refreshment that may be drained with a minimum loss of time, al most every insect on wings alights on them sooner or later. In short, they run their business on the principle of a cooperative department store. Immense quantities of the most vigorous, because cross-fertilized, seed being set in every patch, small wonder that our fields are white with daisies - a long and a merry life to them!

\section{Tansy; Bitter-buttons}

\section{Tanacetum vulgare}

Flower-heads-Small, round, of tubular florets only, packed within a depressed involucre, and borne in flat-topped corymbs. Stem: $1-1 / 2$ to $3 \mathrm{ft}$. tall, leafy. Leaves: Deeply and pinnately cleft into narrow, toothed divisions; strong scented. 
Preferred Habitat—Roadsides; commonly escaped from gardens.

Flowering Season-July-September.

Distribution-Nova Scotia, westward to Minnesota, south to Missouri and North Carolina. Naturalized from Europe.

"In the spring time, are made with the leaves hereof newly sprung up, and with eggs, cakes or Tansies which be pleasant in taste and goode for the Stomache," wrote quaint old Gerarde. That these were popular dainties in the seventeenth century we further know through Pepys who made a "pretty dinner" for some guests, to wit: "A brace of stewed carps, six roasted chickens, and a jowl of salmon, hot, for the first course; a tansy, and two neat's tongues, and cheese, the second." Cole's "Art of Simpling," published in 1656, assures maidens that tansy leaves laid to soak in buttermilk for nine days "maketh the complexion very fair." Tansy tea, in short, cured every ill that flesh is heir to, according to the simple faith of medieval herbalists-a a faith surviving in some old women even to this day. The name is said to be a corruption of athanasia, derived from two Greek words meaning immortality. When some monks in reading Lucian came across the passage where Jove, speaking of Ganymede to Mercury, says, "Take him hence, and when he has tasted immortality let him return to us," their literal minds inferred that this plant must have been what Ganymede tasted, hence they named it athanasia! So great credence having been given to its medicinal powers in Europe, it is not strange the colonists felt they could not live in the New World without tansy. Strong-scented pungent tufts topped with bright yellow buttons-runaways from old gardensare a conspicuous feature along many a roadside leading to colonial homesteads.

Common or Plumed Thistle

\section{Cirsium}

Is land fulfilling the primal curse because it brings forth thistles? So thinks the farmer, no doubt, but not the goldfinches which daintily feed among the fluffy seeds, nor the bees, nor the "painted lady," which may be seen in all parts of the world where thistles grow, hovering about the beautiful rose-purple flowers. In the prickly cradle of leaves, the caterpillar of this thistle butterfly weaves a web around its main food store.

When the Danes invaded Scotland, they stole a silent night march upon the Scottish camp by marching barefoot; but a Dane inadvertently stepped on a this- 
tle, and his sudden, sharp cry, arousing the sleeping Scots, saved them and their country; hence the Scotch emblem.

From July to November blooms the Common, Burr, Spear, Plume, Bank, Horse, Bull, Blue, Button, Bell, or Roadside Thistle (C. lanceolatum or Carduus lanceolatus), a native of Europe and Asia, now a most thoroughly naturalized American from Newfoundland to Georgia, westward to Nebraska. Its violet flower-heads, about an inch and a half across, and as high as wide, are mostly solitary at the ends of formidable branches, up which few crawling creatures venture. But in the deep tube of each floret there is nectar secreted for the flying visitor who can properly transfer pollen from flower to flower. Such a one suffers no inconvenience from the prickles, but, on the contrary, finds a larger feast saved for him because of them. Dense, matted, wool-like hairs, that cover the bristling stems of most thistles, make climbing mighty unpleasant for ants, which ever delight in pilfering sweets. Perhaps one has the temerity to start upward.

"Fain would I climb, yet fear I to fall,"
"If thy heart fail thee, climb not at all,"

might be the ant's passionate outburst to the thistle, and the thistle's reply, instead of a Sir Walter and Queen Elizabeth couplet. Long, lance-shaped, deeply cleft, sharply pointed, and prickly dark green leaves make the ascent almost unendurable; nevertheless, the ant bravely mounts to where the bristle-pointed, overlapping scales of the deep green cup hold the luscious flowers. Now his feet becoming entangled in the cottony fibres wound about the scaly armor, and a bristling bodyguard thrusting spears at him in his struggles to escape, death happily releases him. All this tragedy to insure the thistle's cross-fertilized seed that, seated on the autumn winds, shall be blown far and wide in quest of happy conditions for the offspring!

Sometimes the Pasture or Fragrant Thistle (C. pumilum or Carduus odoratus) still further protects its beautiful, odorous purple or whitish flower-head, that often measures three inches across, with a formidable array of prickly small leaves just below it. In case a would-be pilferer breaks through these lines, however, there is a slight glutinous strip on the outside of the bracts that compose the cup wherein the nectar-filled florets are packed; and here, in sight of Mecca, he meets his death, just as a bird is caught on limed twigs. The Pasture Thistle, whose range is only from Maine to Delaware, blooms from July to September.

Chicory; Succory; Blue Sailors; Bunk 
Cichorium Intybus

Flower-head-Bright, deep azure to gray blue, rarely pinkish or white, 1 to $1-1 / 2$ in. broad, set close to stem, often in small clusters for nearly the entire length; each head a composite of ray flowers only, 5-toothed at upper edge, and set in a flat green receptacle. Stem: Rigid, branching, 1 to $3 \mathrm{ft}$. high. Leaves: Lower ones spreading on ground, 3 to $6 \mathrm{in}$. long, spatulate, with deeply cut or irregular edges, narrowed into petioles, from a deep tap-root; upper leaves of stem and branches minute, bract-like.

Preferred Habitat-Roadsides, waste places, fields.

Flowering Season-July-October.

Distribution-Common in eastern United States and Canada, south to the Carolinas; also sparingly westward to Nebraska.

At least the dried and ground root of this European invader is kilown to hosts of people who buy it undisguised or not, according as they count it an improvement to their coffee or a disagreeable adulterant. So great is the demand for chicory that, notwithstanding its cheapness, it is often in its turn adulterated with roasted wheat, rye, acorns, and carrots. Forced and blanched in a warm, dark place, the bitter leaves find a ready market as a salad known as "barbe de Capucin" by the fanciful French. Endive and dandelion, the chicory's relatives, appear on the table, too in spring, where people have learned the possibilities of salads, as they certainly have in Europe.

From the depth to which the tap-root penetrates, it is not unlikely the succory derived its name from the Latin succurrere $=$ to run under. The Arabic name chicourey testifies to the almost universal influence of Arabian physicians and writers in Europe after the Conquest. As chicoree, achicoria, chicoria, cicorea, chicorie, cichorei, cikorie, tsikorei, and cicorie the plant is known respectively to the French, Spanish, Portuguese, Italians, Germans, Dutch, Swedes, Russians, and Danes.

On cloudy days or in the morning only throughout midsummer the "peasant posy" opens its "dear blue eyes"

\author{
"Where tired feet \\ Toil to and fro; \\ Where flaunting Sin
}


May see thy heavenly hue,

Or weary Sorrow look from thee

Toward a tenderer blue!"

- Margaret Deland.

In his "Humble Bee" Emerson, too, sees only beauty in the

"Succory to match the sky;"

but, mirabile dictu, Vergil, rarely caught in a prosaic, practical mood, wrote,

"And spreading succ'ry chokes the rising field."

Common Dandelion; Blowball; Lion's-tooth; Peasant's Clock

Taraxacum officinale (T. Dens-leonis)

Flower-head-Solitary, golden yellow, 1 to $2 \mathrm{in}$. across, containing 150 to 200 perfect ray florets on a flat receptacle at the top of a hollow, milky scape 2 to 18 in. tall. Leaves: From a very deep, thick, bitter root; oblong to spatulate in outline, irregularly jagged.

Preferred Habitat — Lawns, fields, grassy waste places.

Flowering Season-Every month in the year.

Distribution-Around the civilized world.

"Dear common flower that grow'st beside the way, Fringing the dusty road with harmless gold.

"Gold such as thine ne'er drew the Spanish prow Through the primeval hush of Indian seas, Nor wrinkled the lean brow

Of age, to rob the lover's heart of ease.

'Tis the spring's largess, which she scatters now

To rich and poor alike, with lavish hand;

Though most hearts never understand

To take it at God's value, but pass by

The offered wealth with unrewarded eye." 
Let the triumphant Anglo-Saxon with dreams of expansion that include the round earth, the student of sociology who wishes an insight into cooperative methods as opposed to individualism, the young man anxious to learn how to get on, parents with children to be equipped for the struggle for existence, business men and employers of labor, all sit down beside the dandelion and take its lesson to heart. How has it managed without navies and armies-for it is no imperialist-to land its peaceful legions on every part of the civilized world and take possession of the soil? How can this neglected wayside composite weed triumph over the most gorgeous hothouse individual on which the horticulturist expends all the science at his command; to flourish where others give up the struggle defeated; to send its vigorous offspring abroad prepared for similar conquest of adverse conditions wherever met; to attract myriads of customers to its department store, and by consummate executive ability to make every visitor unwittingly contribute to its success? Any one who doubts the dandelion's fitness to survive should humble himself by spending days and weeks on his knees, trying to eradicate the plant from even one small lawn with a knife, only to find the turf starred with golden blossoms, or, worse still from his point of view, hoary with seed balloons the following spring.

Deep, very deep, the stocky bitter root penetrates where heat and drought affect it not, nor nibbling rabbits, moles, grubs of insects, and other burrowers break through and steal. Cut off the upper portion only with your knife, and not one, but several, plants will likely sprout from what remains; and, however late in the season, will economize stem and leaf to produce flowers and seeds, cuddled close within the tuft, that set all your pains at naught. "Never say die" is the dandelion's motto. An exceedingly bitter medicine is extracted from the root of this dandelion. Likewise are the leaves bitter. Although they appear so early in the spring, they must be especially tempting to grazing cattle and predaceous insects, the rosettes remain untouched, while other succulent, agreeable plants are devoured wholesale. Only Italians and other thrifty Old World immigrants, who go about then with sack and knife collecting the fresh young tufts, give the plants pause; but even they leave the roots intact. When boiled like spinach or eaten with French salad dressing, the bitter juices are extracted from the leaves or disguisedmean tactics by an enemy outside the dandelion's calculation. All nations know the plant by some equivalent for the name dent de lion = lion's tooth, which the jagged edges of the leaves suggest.

After flowering, it again looks like a bud, lowering its head to mature seed unobserved. Presently rising on a gradually lengthened scape to elevate it where there is no interruption for the passing breeze from surrounding rivals, the transformed 
head, now globular, white, airy, is even more exquisite, set as it is with scores of tiny parachutes ready to sail away. A child's breath puffing out the time of day, a vireo plucking at the fluffy ball for lining to put in its nest, the summer breeze, the scythe, rake, and mowing machines, sudden gusts of winds sweeping the country before thunderstorms - these are among the agents that set the flying vagabonds free. In the hay used for packing they travel to foreign lands in ships, and, once landed, readily adapt themselves to conditions as they find them. After soaking in the briny ocean for twenty-eight days-long enough for a current to carry them a thousand miles along the coast-they are still able to germinate.

Tall or Wild Lettuce; Wild Opium; Horse-weed

\section{Lactuca canadensis}

Flower-heads-Numerous, small, about $1 / 4$ in. across, involucre, cylindric, rays pale yellow; followed by abundant, soft, bright white pappus; the heads growing in loose, branching, terminal clusters. Stem: Smooth, 3 to $10 \mathrm{ft}$. high, leafy up to the flower panicle; juice milky. Leaves: Upper ones lance-shaped; lower ones often $1 \mathrm{ft}$. long, wavy-lobed, often pinnatifid, taper pointed, narrowed into flat petioles.

Preferred Habitat-Moist, open ground; roadsides.

Flowering Season-June-November.

Distribution-Georgia, westward to Arkansas, north to the British Possessions.

Few gardeners allow the table lettuce (sativa) to go to seed; but as it is next of kin to this common wayside weed, it bears a strong likeness to it in the loose, narrow panicles of cream-colored flowers, followed by more charming, bright, white little pompons. Where the garden varieties originated, or what they were, nobody knows. Herodotus says lettuce was eaten as a salad in 550 B.C.; in Pliny's time it was cultivated, and even blanched, so as to be had at all seasons of the year by the Romans. Among the privy-purse expenses of Henry VIII is a reward to a certain gardener for bringing "lettuze" and cherries to Hampton Court. Quaint old Parkinson, enumerating "the vertues of the lettice," says, "They all cool a hot and fainting stomache." When the milky juice has been thickened (lactucarium), it is sometimes used as a substitute for opium by regular practitioners-a fluid employed by the plants themselves, it is thought, to discourage creatures from feasting at their expense. Certain caterpillars, however, eat the leaves readily; but offer lettuce or poppy foliage to grazing cattle, and they will go without food rather than touch it. 
"What's one man's poison, Signer, Is another's meat or drink."

Rabbits, for example, have been fed on the deadly nightshade for a week without injury.

Orange or Tawny Hawkweed; Golden Mouse-ear Hawkweed; Devil's Paint-brush

Hieracium aurantiacum

Flower-heads-Reddish orange; 1 in. across or less, the 5-toothed rays overlapping in several series; several heads on short peduncles in a terminal cluster. Stem: Usually leafless, or with 1 to 2 small sessile leaves; 6 to $20 \mathrm{in}$. high, slender, hairy, from a tuft of hairy, spatulate, or oblong leaves at the base.

Preferred Habitat—Fields, woods, roadsides, dry places.

Flowering Season-June-September.

Distribution-Pennsylvania and Middle states northward into British Possessions.

A popular title in England, from whence the plant originally came, is Grimm the Collier. All the plants in this genus take their name from hierax-a hawk, because people in the old country once thought that birds of prey swooped earthward to sharpen their eyesight with leaves of the hawkweed, hawkbit, or speerhawk, as they are variously called. Transplanted into the garden, the orange hawkweed forms a spreading mass of unusual, splendid color.

The Rattlesnake-weed, Early or Vein-leaf Hawkweed, Snake or Poor Robin's Plantain (H. venosum), with flower-heads only about half an inch across, sends up a smooth, slender stem, paniculately branched above, to display the numerous dandelion-yellow disks as early as May, although October is not too late to find this generous bloomer in pine woodlands, dry thickets, and sandy soil. Purplishveined oval leaves, more or less hairy, that spread in a tuft next the ground, are probably as efficacious in curing shake bites as those of the Rattlesnake Plantain. When a credulous generation believed that the Creator had indicated with some sign on each plant the special use for which each was intended, many leaves were found to have veinings suggesting the marks on a snake's body; therefore, by simple reasoning, they must extract venom. How delightful is faith cure! 


\section{COLOR KEY}

\section{BLUE TO PURPLE FI.OWERS}

Asters, Blue and Purple

Beard-tongues

Bittersweet (Nightshade)

Bluets

Brooklime, American

Chicory

Day-flowers

Eye-bright

Flags, Blue

Fluellin

Forget-me-nots

Gentians

Harebell

Iron-weed

Liverwort

Monkey-flower

Orchids, Purple-fringed

Peanut, Hog

Pickerel-weed

Plantain, Robin's

Self-heal

Skullcaps

Speedwells

Tare, Blue 
Thistles

Toadflax, Blue

Venus' Looking Glass

Vervain, Blue

Violets, Blue and Purple

Viper's Bugloss

\section{MAGENTA TO PINK}

Arbutus, Trailing

Arethusa

Bergamot, Wild

Bindweed, Hedge

Bitter-bloom

Calopogon

Campion, Corn

Catch-flies

Clovers

Dogbanes

Geraniums, Wild

Gerardias

Hardhack

Herb-Robert

Honeysuckle, Wild

Joe-Pye weed

Knotwood, Pink

Laurels

Lobelias, Blue

Lupine, Wild

Milkworts

Moccasin Flower, Pink

Motherwort

Orchid, Showy

Persicaria, Common

Pink, Moss

Pipsissewa

Polygala, Fringed

Raspberry, Purple-flowering

Rhododendron, American

Rose, Mallow 
Roses, Wild

Snake-head

Soapwort

Willow-herb, Spiked

Wood-sorrel, Violet

Wood-sorrel, White

\section{WHITE AND GREENISH}

Anemone, Wood

Arrow-head, Broad-leaved

Aster, White

Baneberries

Blackberries

Bloodroot

Button-Bush

Camomile

Campion, Starry

Carrot, Wild

Chickweed, Common

Clover, White Sweet

Cohosh, Black

Coolwort

Culver's Root

Dodder, Gronovius'

Dogwoods

Dutchman's Breeches

Everlastings

Gold-thread

Grass of Parnaoeas

Hawthorn, Common

Hellebore, White

Indian Pipe

Jamestown weed

Ladies' Tresses

May Apple

Meadow-rues

Meadow-sweets

Mitrewort, False

New Jersey Tea 
Orchids, White-fringed

Partridge Vine

Pokeweed

Saxifrage, Early

Shepherd's Purse

Solomon's Seals

Spikenard, American

Spikenard, Wild

Spring Beauty

Squirrel Corn

Star-flower

Star-grass

Sundews

Violets, White

Virgin's Bower

Wake-Robin, Early

Water-lily, White

Wintergreen, Creeping

Yarrow

YELLOW AND ORANGE

Adder's Tongue, Yellow

Aster, Golden

Barberry, American

Black-eyed Susan

Butter-and-eggs

Buttercups

Butterfly-weed

Carrion-flower

Celandine, Greater

Clintonia, Yellow

Dandelions

Devil's Paint-brush

Elecampane

Evening Primrose

Five-finger

Foxgloves, False

Golden-rods

Hawkweeds 
Indigo, Wild

Jewel-weed

Lettuce, Wild

Lily, Blackberry

Lily, Wild Yellow

Marigold, Marsh

Meadow-gowan

Moccasin-flower, Yellow

Mullein, Great

Mullein, Moth

Mustards

Orchis, Yellow-fringed

Parsnips, Wild

Rockrose, Canadian

St. John's-wort

Senna, Wild

Sneezeweed

Star-grass

Tansy

Violets, Yellow

Water-lily, Yellow

Witch-hazel

\section{RED AND INDEFINITES}

Betony, Wood

Cardinal Flower

Columbine, Wild

Ground-nut

Jack-in-the-Pulpit

Lily, Red, Wood

Oswego Tea

Painted Cups, Scarlet

Pine Sap

Pitcher-plant

Skunk Cabbage 


\section{GENERAL INDEX OF NAMES}

Aaron's rod

Achillea Millefolium

Actaea alba

Adder's tongue

Agrostemma Githago

Agueweed

Alismaceae

Alleluia

Alsine media

Althaea officinalis

Alum-root

Amaryllidaceae

Amaryllis family

American brooklime

American cowslip

American laurel

American rhododendron

American senna

American white hellebore

Amphicarpa monoica

Anagallis arvensis

Anaphalis margarilacea

Anemone, Star

Anemone, Wood

Anemonella thalictroides

Angel's hair 
Anthemis Cotula

Apios

Apocynaceae

Apocynum androsaemifolium

Apple, May or Hog

Apple, Thorn

Aquilegia canadensis

Araceae

Aralia

Araliaceae

Arbutus, Trailing

Arethusa

Arisaema triphyllum

Arrow-head, Broad-leaved

Arum family

Asclepiadaceae

Asclepias

Asters, Blue and Purple

Aster, Golden

Asters, White

Azalea, Clammy

Azalea, Pink, Purple, or Wild

Azalea, White

Balm, Bee or Fragrant

Balmony

Balsam, Wild

Balsaminaceae

Baneberry, White

Bank thistle

Baptisia tinctoria

Barberry

Barberry family

Bay

Beard-tongue, Hairy

Bee balm

Beech-drops

Beech-drops, False

Beefsteak plant

Belamcanda chinensis

Bell-bind

Bellflower, Clasping 
Bell thistle

Berberidaceae

Berberis vulgaris

Bergamot, Wild

Berry, Scarlet or Snake

Betony, Paul's

Betony, Wood

Bindweed, Blue

Bindweed, Hedge or Great

Bird's-foot violet

Bird's-nest

Bird's-nest, Yellow

Birth-root

Bishop's cap

Bitter-bloom

Bitter-buttons

Bitter-root

Bittersweet

Bitterweed

Blackberry, Highbush

Blackberry lily

Black-eyed Susan

Blind gentian

Blister-flower

Bloodroot

Blowball

Blue bells of Scotland

Blue Curls

Blue-devil

Blue-eyed grass, Pointed

Blue Mountain tea

Blue-sailors

Blue star

Blue-stemmed golden-rod

Blue-thistle

Blue-weed

Bluebell family

Bluets

Bokhara clover

Boneset

Boneset, Tall or Purple 
Borage family

Boraginaceae

Bottle gentian

Bouncing Bet

Boxberry

Bramble

Branching aster

Brassica

Brideweed

Broad-leaved golden-rod

Broad-leaved aster

Broad-leaved kalmia

Brooklime, American

Broom, Yellow or Indigo

Broom-rape family

Bruisewort

Brunella

Buckthorn family

Buckwheat family

Bugbane, Tall

Bulbous buttercup

Bull thistle

Bunchberry

Bunk

Burnet rose

Burr thistle

Butter-and-eggs

Buttercups

Butter-flower

Butterfly-weed

Button-ball shrub

Button-bush

Button thistle

Calf-kill

Calico bush

Calmoun

Calopogon

Caltha palustris

Camomile, Dog's or Foetid

Campanula rotundifolia

Campanulaceae 
Campion, Corn or Red

Campion, Starry

Canada golden-rod

Canada lily

Canadian rockrose

Canker-root

Capsella Bursa-pastoris

Cardinal flower

Cardinal flower, Blue

Carduus

Carpenter weed

Carrion-flower

Carrot, Wild

Caryophyllaceae

Cassia marylandica

Castalia odorata

Castilleja coccinea

Catchfly

Ceanothus americanus

Celandine, Greater

Centaury, Rosy

Cephalanthus occidentalis

Chamaenerion angustifolium

Charlock

Checker-berry

Chelidonium majus

Chelone glabra

Cherokee rose

Chickweed, Common

Chickweed, Red

Chickweed wintergreen

Chicory

Chimaphila

Chrysanthemum Leucanthemum

Chrysopsis

Cichorium Intybus

Cimicifuga racemosa

Cinquefoil, Common

Cirsium

Cistaceae

Clammy Azalea 
Clasping bell-flower

Claytonia

Clematis, Virginia

Clintonia

Closed gentian

Clover, Common red, Purple, Meadow or Honeysuckle

Clover, White or Dutch

Clover, White sweet, Bokhara, or Tree

Cocash

Cockle, Corn

Cod-head

Cohosh

Cohosh, Black

Columbine, Wild

Commelina virginica

Commelinaceae

Compositae

Composite family

Cone-flower, Purple

Convolvulaceae

Convolvulus family

Coolwort

Coptis trifolia

Corn campion

Corn cockle, rose or campion

Corn mustard

Corn, Squirrel

Cornaceae

Cornel, Low or Dwarf

Cornel, Silky

Cornus

Corpse-plant

Cottonweed

Cow lily

Cow vetch

Cowslip, American

Crane's-bill

Crataegus coccinea

Creeping wintergreen

Crosswort

Crowfoot family 
Crowfoot, Tall

Crown-of-the-field

Cruciferae

Cuckoo flower

Culver's root or physic

Curls, Blue

Cuscuta gronovii

Cypripedium acaule

Cypripedium pubescens or hirsutum

Daisy, Blue spring

Daisy, Common

Daisy fleabane

Daisy-leaved fleabane

Daisy, Michaelmas

Daisy, Ox-eye

Daisy, Pig-sty

Daisy, Purple

Daisy, White or Ox-eye

Daisy, Yellow or Ox-eye

Dandelion, Common

Dasystoma flava

Daucus carota

Day-flower

Deer berry

Dense-flowered aster

Devil's paint-brush

Devil's trumpet

Dew-plant

Dicentra canadensis

Dicentra Cucuilaria

Dillweed

Dock, Mullein

Dodder, Gronovius' or Common

Dodecathon Meadia

Dog-fennel

Dog-tooth "violet"

Dogbane family

Dogbane, Spreading or Fly-trap

Dog's Camomile

Dogwood family

Dogwood, Flowering 
Dogwood, Swamp

Downy false foxglove

Downy yellow violet

Dragon's blood

Droseraceae

Dutch clover

Dutchman's breeches

Dwarf cornel

Dwarf wake-robin

Dyer's weed

Ear-drops

Early hawkweed

Early purple aster

Early saxifrage

Eggs-and-bacon

Elecampane

English violet

Epifagus virginiana

Epigaea repens

Epilobium angustifolium

Ericaceae

Erigeron

Erythronium americanum

Eupatorium

Evening primrose

Evening primrose family

Everlasting, Pearly or Large-flowered

Eye-bright

Falcata comosa

False beech-drops

False foxglove, Downy

False miterwort

False sarsaparilla

False Solomon's seal

Farewell summer

Felonwort

Field golden-rod

Field lily

Field milkwort

Field mustard or kale

Field parsnip 
Figwort family

Fire-weed

Five-finger

Flag, Larger blue

Flame lily

Flannel plant

Flat top

Flaxweed

Fleabane, Daisy

Fleabane, Daisy-leaved

Fleabane, Salt-marsh

Fleur-de-lis

Flower-de-luce

Flowering dogwood

Flowering wintergreen

Fluellin

Fly-trap dogbane

Foam-flower

Foetid camomile

Forget-me-not

Four-leaved loosestrife

Foxglove, Downy false

Fragrant balm

Fragrant thistle

Fringed gentian

Fringed milkwort

Frost-flower or Frost-wort

Frost-weed

Frost-weed, Hoary

Frost-weed, Long-branched

Fuller's herb

Fumariaceae

Fumitory family

Garget

Gaultheria procumbens

Gay orchis

Gay wings

Gentian, Closed, Blind, or Bottle

Gentian family

Gentian, Fringed

Gentiana 
Gentianaceae

Geraniaceae

Geranium family

Geranium Robertianum

Geranium, Wild or Spotted

Gerardia

Gerardia, Large purple

Ghost-flower

Giant St. John's-wort

Giant sunflower

Ginseng family

Globe-flower

Gold-thread

Goldcups

Golden Jerusalem

Golden mouse-ear hawkweed

Golden-rods

Grass of Parnassus

Grass pink

Gravel-root

Great bindweed

Great laurel

Great lobelia

Great mullein

Great rhododendron

Great St. John's-wort

Great willow-herb

Greater celandine

Gronovius' dodder

Ground laurel

Ground-nut

Ground pink

Groundhele

Gulf orchis

Habenaria blephariglottis

Habenaria ciliaris

Habenaria fimbriata or grandiflora

Habenaria flava

Hairbell

Hairy beard-tongue

Hairy golden aster 
Hamamelidaceae

Hardhack

Harebell

Haw, Red

Hawkweed, Early or Vein leaf

Hawkweed, Golden mouse-ear

Hawkweed, Orange or Tawny

Hawthorn

Heal-all

Heal-all, High

Heart-leaved aster

Heart-of-the-earth

Hearts, White

Heath aster, White

Heath family

Hedge bindweed

Hedge mustard

Hedge pink

Helenium autumnale

Helianthemum

Helianthus giganteus

Hellebore

Helmet-flower

Hepatica

Herb Robert

Hibiscus Moscheutos

Hieracium

Highbush blackberry

High heal-all

Hoary frost-weed

Hog apple

Hog peanut

Honey-balls

Honey-bloom

Honey lotus

Honeysuckle clover

Honeysuckle, Swamp

Honeysuckle, Wild

Hooded blue violet

Hoodwort

Horse thistle 
Horse-weed

Horsefly-weed

Horseheal

Houstonia

Huntsman's cup

Hypericaceae

Hypericum

Hypoxis hirsuta or erecta

Hyssop, Wild

Ice-plant

Ill-scented wake-robin

Immortelle

Impatiens aurea or pallida

Impatiens biflora or fulva

Indian dipper

Indian paint

Indian paint-brush

Indian pink

Indian pipe

Indian poke

Indian root

Indian sage

Indian turnip

Indian's plume

Indigo broom

Indigo, Wild

Ink-berry

Innocence

Inula Helenium

Iridaceae

Iris, Blue

Iris family

Iris versicolor

Iron-weed

Itch-weed

Jack-in-the-pulpit

Jamestown weed

Jewel-weed

Jimson weed

Joe-Pye weed

Jointweed, Pink 
Kalmia

Kalmia, Broad-leaved

Kidney liver-leaf

Kidney-root

Kingcup

Kinnikinnick

Knotweed, Pink

Labiatae

Lactuca canadensis

Lady's eardrops

Lady's nightcap

Lady's slippers

Lady's thimble

Lady's tresses or traces, Nodding

Lamb-kill

Lance-leaved violet

Large aster

Larger blue flag

Large-flowered everlasting

Large-flowered wake-robin

Large purple gerardia

Large yellow lady's slipper

Large yellow pond or water lily

Late purple aster

Laurel, Great

Laurel, Ground

Laurel, Mountain or American

Laurel, Narrow-leaved

Legouzia perfoliata

Leguminosae

Lemon, Wild

Leonurus Cardiaca

Leptandra virginica

Lettuce, Tall or Wild

Liliaceae

Lilium canadense

Lilium philadelphicum

Lilium superbum

Lily, Cow

Lily family

Lily, Large yellow pond or water 
Lily, Pond

Lily, Sweet-scented white water

Limodorum tuberosum

Linaria

Lion's Tooth

Liver-leaf

Liverwort

Lobelia family

Lobelia, Great

Lobelia, Red

Lobeliaceae

Long-branched frost-weed

Loosestrife, Four-leaved or Whorled

Lotus, Honey

Lousewort

Love-me, love-me-not

Love me

Love vine

Low cornel

Low purple aster

Lupine, Wild

Lupinus perennis

Lysimachia quadrifolia

Mad-dog skullcap

Madder family

Madnep

Madweed

Mallow family

Mallow, Marsh

Mallow rose

Malvaceae

Mandrake

March violet

Marguerite

Marigold, Marsh

Marsh buttercup

Marsh mallow

Marsh marigold

Marsh pink

Maruta Cotula

May apple 
May weed

Mayflower

Meadow buttercup, Common

Meadow clover

Meadow-gowan

Meadow lily

Meadow rose

Meadow-rues

Meadow scabish

Meadow-sweet

Meadow violet

Melilot, White

Melilotus alba

Michaelmas daisy

Milfoil

Milkweed, Common

Milkweed family

Milkweed, Orange

Milkweed, Purple

Milkwort, Common, Field, or Purple

Milkwort family

Milkwort, Fringed

Mimulus ringens

Mint family

Mitchella vine

Miterwort

Miterwort, False

Mitella diphylla

Moccasin flowers

Monarda

Monkey-flower

Monotropa Hypopitis

Monotropa uniflora

Moonshine

Morning-glory, Wild

Moss pink

Moth mullein

Mother's heart

Motherwort

Mountain laurel

Mountain mint 
Mountain tea

Mouse-ear

Mouse-ear hawkweed, Golden

Mullein dock

Mullein, Great

Mullein, Moth

Mustard family

Mustards

Myosotis scorpioides or palustris

Nancy-over-the-ground

Narrow-leaved laurel

New England aster

New Jersey tea

Nigger-head

Night willow-herb

Nightshade

Nightshade family

Noble liverwort

Nodding ladies' tresses or traces

Nodding wake-robin

None-so-pretty

Nosebleed

Nuphar advena

Nymphaea advena

Nymphaea odorata

Nymphaeaceae

Oenothera biennis

Old maid's bonnets

Old maid's pink

Old man's beard

Old man's pepper

Onagraceae

Opium, Wild

Orange-root

Orchidaceae

Orchis family

Orchis, Gulf, Tubercled, or Sinall pale green

Orchis, Large or Early purple-fringed

Orchis spectabilis

Orchis, White-fringed 
Orchis, Yellow-fringed

Orobanchaceae

Oswego tea

Ox-eye daisy

Oxalidaceae

Oxalis acetosella

Oxalis violacea

Paint-brush, Devil's

Paint-brush, Indian

Paint, Indian

Painted cup, Scarlet

Painted trillium

Pale touch-me-not

Papaveraceae

Pardanthus chinensis

Parnassia

Parnassus, Grass of

Partridge-berry

Partridge vine

Parsley family

Parsnip, Wild or Field

Pastinaca sativa

Pasture thistle

Paul's betony

Pea, Wild

Peanut, Wild or Hog

Pearly everlasting

Peasant's clock

Pedicularis canadensis

Pentstemon hirsutus or pubescens

Pepperidge-bush

Persicaria, Common

Philadelphia lily

Phlox subulata

Physic, Culver's

Phytolaccaceae

Pickerel-weed

Pig-sty daisy

Pigeon-berry

Pimpernel, Scarlet

Pine, Prince's 
Pine sap

Pink family

Pink, Grass

Pink, Ground or Moss

Pink, Hedge or Old maid's

Pink, Indian

Pink, Sea or Marsh

Pink, Swamp

Pink, Wild

Pinxter flower

Pipe, Indian

Pipsissewa

Pipsissewa, Spotted

Pitcher-plant

Pitcher-plant family

Plantain, Snake or Poor Robin's

Pleurisy-root

Plume golden-rod

Plume thistle

Plumed thistle

Podophyllum peltatum

Pointed blue-eyed grass

Poison-flower

Pokeweed family

Polemoniaceae

Polemonium family

Polygala, Fringed

Polygala, Purple

Polygala sanguinea or viridescens

Polygalaceae

Polygonaceae

Polygonatum biflorum

Polygonum pennsylvanicum

Pond lily

Pontederia cordata

Poor man's weatherglass

Poor Robin's plantain

Poppy family

Portulacaceae

Potentilla canadensis

Pride of Ohio 
Primrose, Evening

Primrose family

Primrose-leaved violet

Primulaceae

Prince's pine

Prunella vulgaris

Puccoon, Red

Pulse family

Purple-flowering raspberry

Purple-fringed orchis, Large or Early

Purple-stemmed aster

Purslane family

Quaker bonnets

Quaker ladies

Quaker lady

Queen Anne's lace

Queen-of-the-meadow

Ranunculaceae

Ranunculus acris

Raspberry, Purple-flowering or Virginia

Rattlesnake-weed

Red-root

Red-stalked aster

Rhamnaceae

Rhododendron, American or Great

Rhododendron maximum

Rhododendron nudiflorum

Rhododendron viscosum

River-bush

Roadside thistle

Robert, Herb

Robert's plantain

Robin, Red

Robin's plantain

Rockrose, Canadian

Rockrose family

Root, Indian

Rosa

Rosaceae

Rose, Burnet

Rose, Corn 
Rose family

Rose, Mallow

Rose mallow, Swamp

Rose of Plymouth

Rose-pink

Rose-tree

Rose, Wild

Rosemary, White

Rosy centaury

Round-leaved sundew

Round-lobed liver-leaf

Rubiaceae

Rubus odoratus

Rubus villosus

Rudbeckia hirta

Rue anemone

Rutland beauty

Sabbatia

Sabbatia, Square-stemmed

Sagittaria latifolia

Sagittaria variabilis

Sailors, Blue

St. John's-wort family

St. John's-worts

Salt-marsh fleabane

Sanguinaria canadensis

Saponaria officinalis

Sarracenaceae

Sarsaparilla, Wild or False

Saxifragaceae

Saxifrage family

Scabious, Sweet

Scabish, Meadow

Scoke

Scorpion grass

Scrophularaceae

Scutellaria laterifolia

Sea pink

Seaside purple aster

Self-heal

Senna, Wild or American 
Sessile-flowered wake-robin

Shanks, Red

Sharp-toothed golden-rod

Sheep-laurel

Sheep-poison

Shellflower

Shepherd's purse

Shepherd's weatherglass or clock

Shooting star

Showy orchis

Showy purple aster

Shrubby St. John's-wort

Side-saddle flower

Silene pennsylvanica or caroliniana

Silene stellata

Silkweed

Silky cornel

Silver cap

Silver leaf

Simpler's joy

Sisymbrium officinale

Sisyrinchium angustifolium

Skullcap, Mad-dog

Skunk cabbage

Small pale green orchis

Smartweed

Smilacina racemosa

Smilax herbacea

Smooth aster

Smooth yellow violet

Smoother rose

Snake berry

Snake-flower

Snake grass

Snake-head

Snake plantain

Snakeroot, Black

Snap weed

Sneezeweed

Snowball, Wild

Soapwort 
Solanaceae

Soldier's cap

Solidago

Solomon's seal

Solomon's seal, False

Solomon's zig-zag

Spatterdock

Spear thistle

Specularia perfoliata

Speedwell, Common

Spice berry

Spiderwort family

Spignet

Spiked willow-herb

Spikenard

Spikenard, Wild

Spiraea salicifolia

Spiraea tomentosa

Spiranthes cernua

Spoonwood

Spotted geranium

Spotted touch-me-not

Spotted wintergreen or pipsissewa

Spreading dogbane

Spring beauty

Spring daisy, Blue

Spring orchis

Square-stemmed sabbatia

Squaw-berry

Squirrel corn

Squirrel cup

Star anemone

Star, Blue

Star-flower

Star-grass, Yellow

Star, Shooting

Starry aster

Starry campion

Starwort

Starwort, Yellow

Starworts 
Starworts, Blue and Purple

Steeple bush

Stellaria media

Stemless lady's slipper

Stramonium

Strangle-weed

Succory

Sundew family

Sundial

Sunflower, Swamp

Sunflower, Tall or Giant

Swallow-wort

Swamp buttercup

Swamp cabbage

Swamp dogwood

Swamp pink or honeysuckle

Swamp rose

Swamp rose-mallow

Swamp sunflower

Swanweed

Sweet clover, White

Sweet golden-rod

Sweet scabious

Sweet-scented white water-lily

Sweet violet

Sweet white violet

Sweetbrier

Symplocarpus foetidus

Syndesmon thalictroides

Tall boneset

Tall bugbane

Tall crowfoot

Tall hairy golden-rod

Tall lettuce

Tall meadow-rue

Tall sunflower

Tanacetum vulgare

Tank

Tansy

Tare, Blue, Tufted, or Cow

Tawny hawkweed 
Tea, Mountain or Ground

Tea, Oswego

Thalictrum

Thistle, Burr, Spear, Plume, Bank, Common, Horse, Bull,

Blue, Button,

Bell, or Roadside

Thistle, Common or Plumed

Thistle, Pasture or Fragrant

Thorn apple

Thorn, White or Scarlet fruited

Thoroughwort, Common

Thoroughwort, Purple

Tiarella cordifolia

Tinegrass

Toadflax, Blue or Wild

Toadflax, Yellow

Touch-me-not family

Trailing arbutus

Traveller's joy

Tree clover

Trientalis americana

Trifolium pratense

Trifolium repens

Trilliums

Trout lily

True wood-sorrel

Trumpet-leaf

Trumpet weed

Tubercled orchis

Tufted buttercup

Tufted vetch

Turban lily

Turk's cap

Turtle-head

Twin-berry

Umbelliferae

Vein-leaf hawkweed

Velvet plant

Venus' lady's slipper

Venus' looking-glass

Venus' pride 
Veratrum viride

Verbascum

Verbenaceae

Vernonia noveboracensis

Veronica

Vervain, Blue

Vervain family

Vetch, Blue, Tufted, or Cow

Vicia Cracea

Viola

Violaceae

Violet, Bird's-foot

Violet, Common purole, Meadow, or Hooded blue

"Violet," Dog-tooth

Violet, Downy yellow

Violet, English, March or Sweet

Violet family

Violet, Lance-leaved

Violet, Primrose-leaved

Violet, Smooth yellow

Violet, Sweet white

Violet wood-sorrel

Viper's bugloss

Viper's herb or grass

Virginia clematis

Virginia day-flower

Virginia raspberry

Virgin's bower

Wake-robin

Water cabbage

Water-lily family

Water nymph

Water-plantain family

Weatherglass, Poor Man's or Shepherd's

Whippoorwill's shoe

White-fringed orchis

White-weed

White-wreathed aster

Whorled loosestrife

Wicky

Wild azalea 
Wild balsam

Wild bergamot

Wild carrot

Wild columbine

Wild geranium

Wild honeysuckle

Wild hyssop

Wild indigo

Wild lady's slipper

Wild lemon

Wild lettuce

Wild lupine

Wild morning-glory

Wild opium

Wild parsnip

Wild pea

Wild peanut

Wild pink

Wild rose

Wild sarsaparilla

Wild senna

Wild snowball

Wild toadflax

Wild yellow lily

Willow-herb, Creator Spiked

Willow-herb, Night

Wind-flower

Wintergreen, Chickweed

Wintergreen, Creeping

Wintergreen, Flowering

Wintergreen, Spotted

Witch-hazel family

Wood anemone

Wood aster

Wood aster, White

Wood betony

Wood lily

Wood lily, White

Woodland golden-rod

Wood-sorrel family

Wood-sorrel, Violet 
Wood-sorrel, White or True

Woody nightshade

Wreath golden-rod

Wrinkle-leaved golden-rod

Yarrow

Yellow-fringed orchis

Yellow-top

Yellow-weed

Zig-zag golden-rod 




Printed in the United States

53471LVS00001BA/14 


3 9999050850849

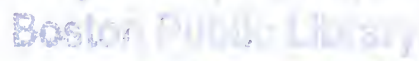

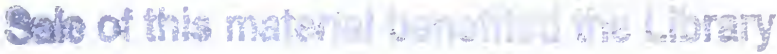




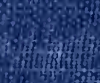

M.1.

M.

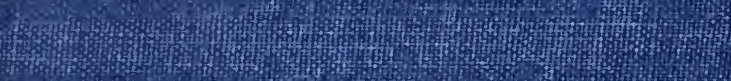

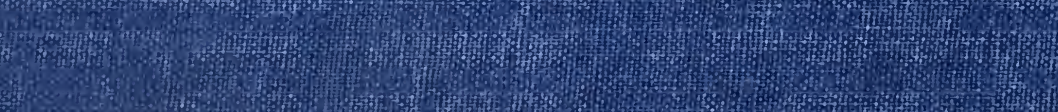

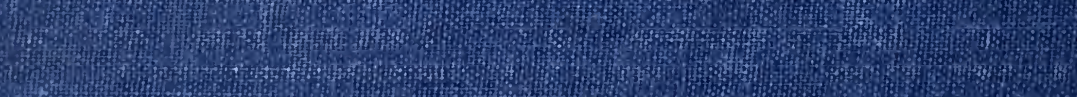

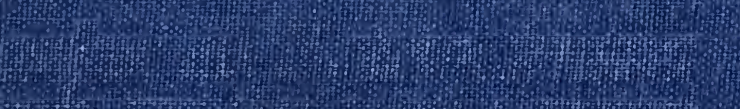
7.

-

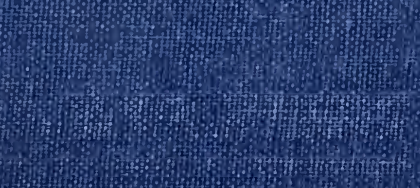

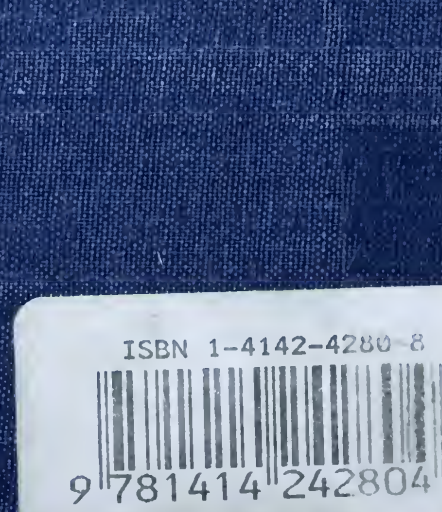

